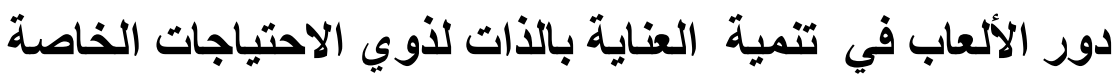

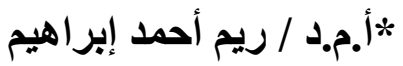

المقدمة ومشكلة البحث:

لقد زاد إهتمام علماء النفس بصفة عامة والصحة النقسية وعلم النفس الرياضي بصفة خاصة بر عاية المعاقين من ذوى الاحتياجات الخاصة حيث أن در اسة هذا الموضوع أصبحت من أهم المشكلات التى لهـ تواجه المجتمعات إذ أنه لا يخلو مجتمع من المجتمعات من وجود نسبة لا يستهان بها من هذه الفئات،

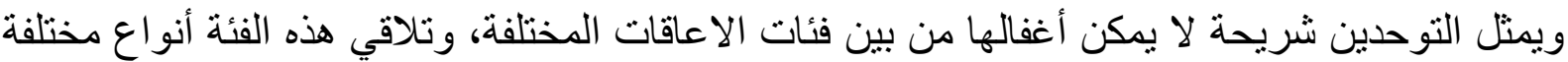
من التعاملات حسب طبيعة المجتمع وثقافته وفلسفته ، فعلي سبيل المثال لا الحصر هنالك مجتمعات ونئ تتعامل مع التوحدين بمنتهي الظلم والقسوة ، ومجتمعات أخري تحاول التخلص منهم في أماكن منعزلة

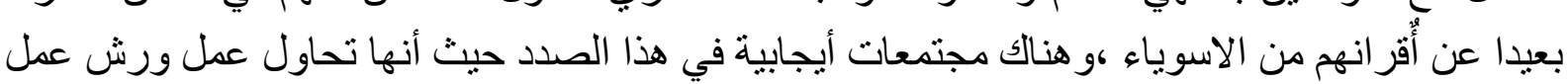

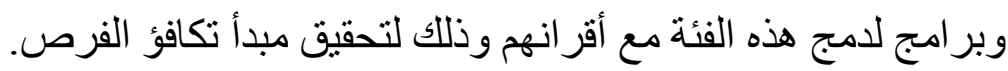

وتري " ليلي ز هران، و عاصم راثد" (0 . . ب م) أن مهار ات العناية بالذات حجر الزاوية في مناهج ذوي الاحتياجات الخاصة مثل تدريب الطفل علي مهار ات غسل اليدين و النظافة الثخصية وآداب المائدة وارتداء الحذاء وخلعه وارتداء الملابس وخلعها.. وبما أن الطفل التوحدي لديه قصور في اكتساب تللك المهار ات فنلجأ إلي تدريبه عليها عن طريق فنيات واسترتيجيات أخري مثل فنيات العلاج باللعب وهو

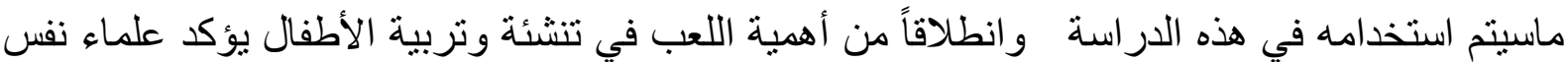
الطفل علي أن اللعب بالنسبة للأطفال وبشكل خاص الطفل الصغير هو الحياة الكاملة ووظيفة الطفل الأولي و عمله الأساسي. (1):YV) وبذللك تري الباحثة أنه من الضروري الربط بين فنيات إستخدام الأنشطة والمهارات والألعاب كوسيلة لتنمية مهار ات العناية بالذات لدي الأطفال التوحديين بسهولة ويتم ذلك من خلال تحديد أنشطة ومهار ات معينة للعب تكون مناسبة لهذة الفئة من الأطفال التوحديين، وبالتالي تشتمل علي تعلم و إتقان وتحسن في مهار ات العناية بالذات.

ولقد أشارت نتائج بعض الدراسات ومنها در اسة "سميرة على " (ب99 (م))، و "عبد الرحمن سيد"

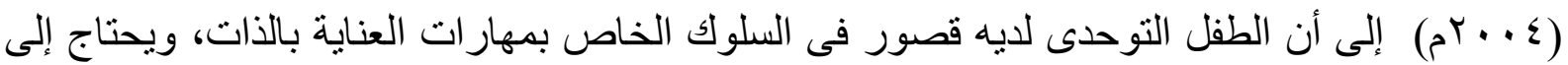

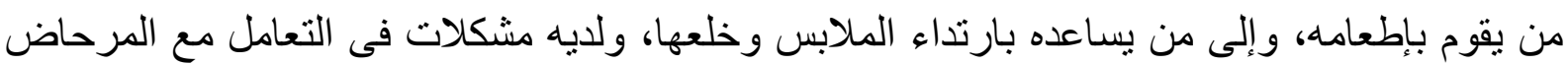
و التغذية، وأيضا أوصت هذه الدراسات بتقديم البرامج التدريبية والإرشادية، والعلاجية مثل العلاج باللعب، بهدف تحسين مهار ات العناية بالذات لديهم، حيث كان لتتوع أساليب التدريب و العلاج سواء كان

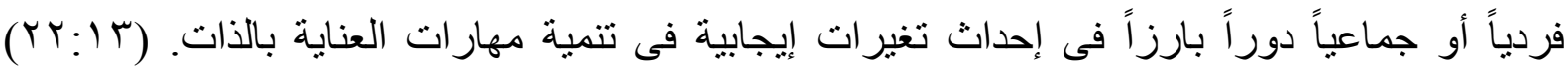
. (rt:IV)

ـ أستاذ مساعد بقسم العلوم التربوية و النفسية والإجتماعية بكلية التربية الرياضية للبنات_ جامعة حلوان.

مجلة بحوث التربية الثاملة ـ كلية التربية الرياضية للبنات - جامعة الزقازيق ـ المجلد الأول ـ للنصف الثاني للابحاث العلمية ـ V ـ Yم 
وتؤكد " إيمان عبيد " (7 ( • rم) أن هناك العديد من الدراسات التى أكدت على أهمية تقديم

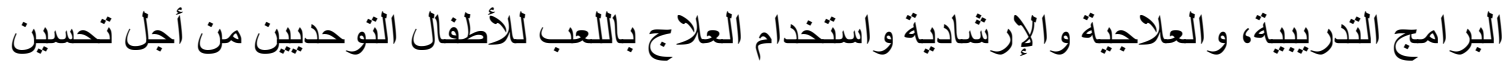

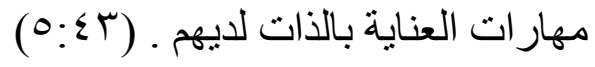

وفى ضوء ما سبق بالإضافة إلى خبرة الباحثة في العمل التطوعي لفترات طويلة مع الفئات الخاصة بثكل عام و التوحديين بشكل خاص وجدت حاجة هذه الفئة للعديد من المقاييس التي تقيس مهار اتهح إلي

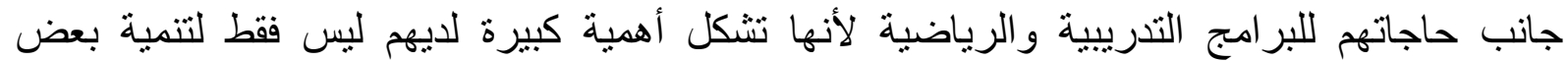

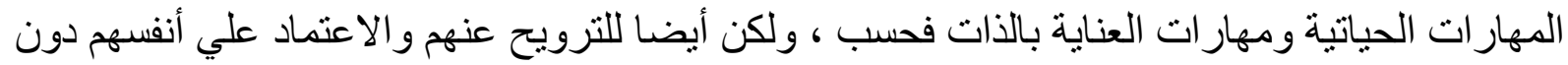
الحاجة إلي مساعدة الغير، ومن هذا المنطلق تسعي الباحثة لإعداد مقياس مهار ات العناية بالذات للأطفال

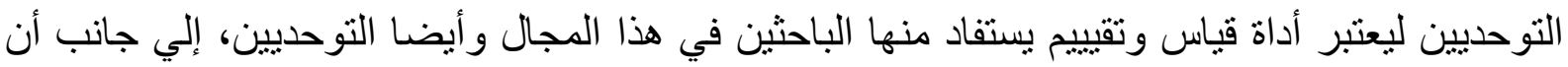
تقترح الباحثة إعداد برنامج علاجي باستخدام اللعب وتطبيقه علي الأطفال التوحديين ومعرفة فعاليته علي زيادة وتحسين مهار ات العناية بالذات عند الأطفال التوحديين. بالفين.

الأهمية النظرية

ـ تكمن أهمية البحث فى تناوله لقطاع هام فى المجتمع وهو التوحديين وهذه الفئة لم تنل حظها من البحث العلمي.

ץ- هذا البحث بعتبر إثراء للمكتبات المصرية، إلي جانب أن الأداتين المقترحتين من قبل الباحثة تعتبر خطوة جديدة في علم النفس الرياضي. r- دراسة مدى أهمية الأنشطة والألعاب و المهار ات المختلفة التي بتضمنها البرنامج في تنمية مهارات العناية بالذات لدى الأطفال التوحديين.

\section{الأهمية التطبيقية}

1 ـ بناء مقياس مهار ات العناية بالذات لدى الأطفال التوحديين. r- إعداد برنامج مفترح بالألعاب وما تتضمنه من أنشطة ومهار ات مختلفة مناسبة وذلك بهذف تنمية وتحسين وزيادة مهار ات العناية بالذات لدى الأطفال التوحديين.

أهداف البحث

1 - بناء مقياس مهار ات العناية بالذات لدى الأطفال التوحديين. ז ـ تأثير برنامج مقترح بالألعاب في تنمية مستوي أداء مهار ات العناية بالذات لدى الأطفال التوحديين. تساؤل البحث ا ـ هل توجد فروق دالة إحصائياً بين القياسين القبلى و البعدى للمجموعة التجريبية فى مستوي أداء مهار ات العناية بالذات لدى الأطفال التوحديين لصالح القياس البعدى؟

مجلة بحوث التربية الثاملة ـ كلية التربية الرياضية للبنات - جامعة الزقازيق ـ المجلد الأول ـ للنصف الثاني للأبحاث العلمية _ V ـ Yم 
Playing : اللعب

هو " النشاط التلقائي الذي يقوم به الطفل ليعبر عما بداخله، ويحاكي الآخرين، لتحقيق حالة من

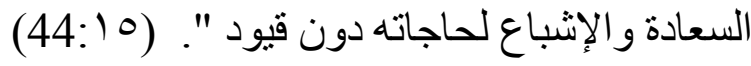

التوحد: Autism

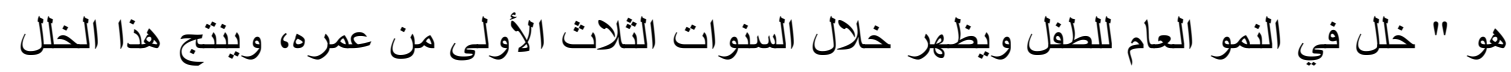

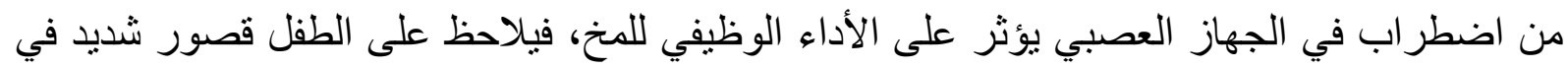
التفاعل الاجتماعي، و النمو الإدر اكي، والتواصل، وفهم اللغة وتأخر شديد في العلاقات الاجتماعية، ويبدي

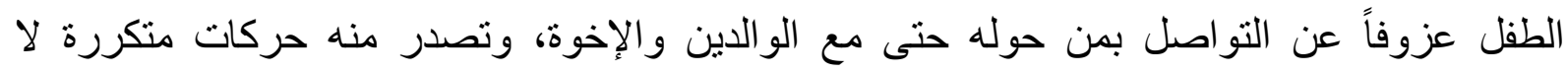
يغير ها.(2116)

\section{العناية بالأات: Self care}

هو "مـا يتطلبـه الطفل من مهام شخصية خاصـة بالمأكل و المشـرب و الملبس و عمليبة إرتداء وخلـع

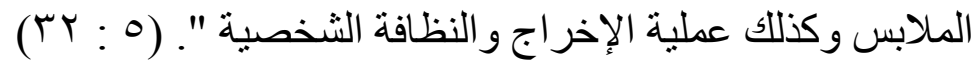

مهارات العناية بالذات:Self care skills هي قدرة التوحديين علي أداء متطلبات الحياة الاساسية ، كتناول الطعام و الثر اب ، و إرتداءالملابس

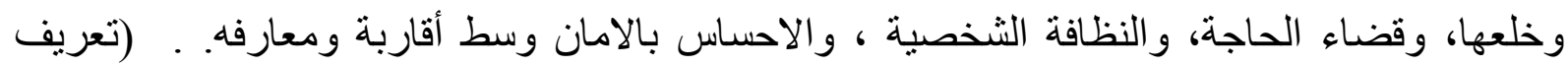
اجر ائي)

\section{البرنامج:Program}

عبارة عن " مجموعة من الانشطة و المهار ات و الالعاب المختارة بطريقة منظمة ومناسبة للأطفال

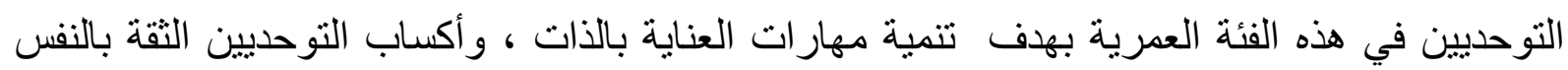
و الاعتماد علي الذات .والتى تشنمل على تناول الطعام، وتناول الثراب، وارتداء الملابس، وعملية

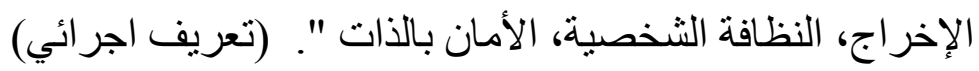
ثانياً : الار اسات السابقة

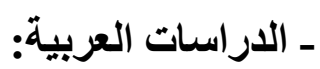
اـ دراسة "إيمان عبيد" (7 1 • Y م) (0) هدفت إلي إعداد برنامج قائم علي الألعاب المائية لتنمية

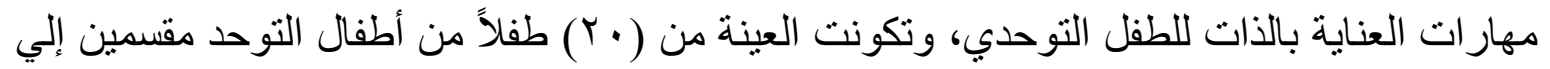

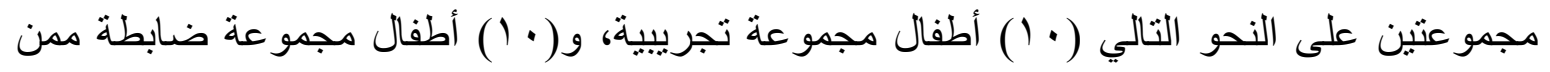

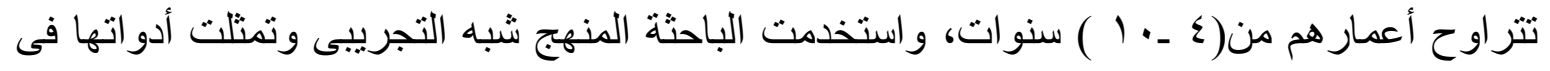

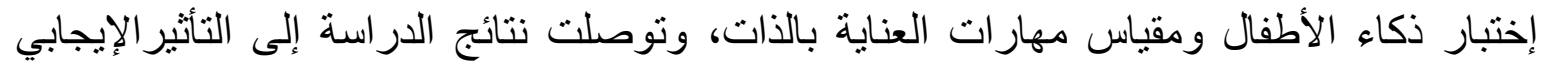
للألعاب المائية علي الطفل التوحدي، وفاعلية تأثير البرنامج علي بلي الطفل التوحدي.

مجلة بحوث التربية الثاملة ـ كلية التربية الرياضية للبنات - جامعة الزقازيق ـ المجلد الأول ـ للنصف الثاني للابحاث العلمية _ V + Yم 


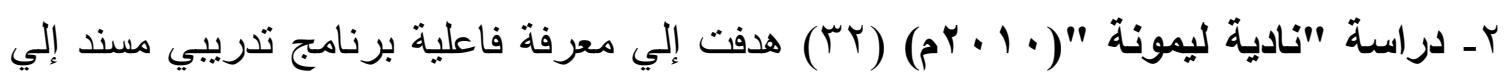

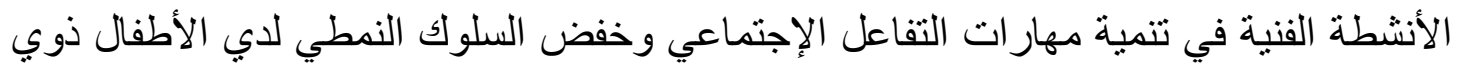
التوحد في الأردن، علي عينه (0 (1) طفلاً من مركز تواصل التوحد بمدينة عمان ، وتتر اوح أعمار هم

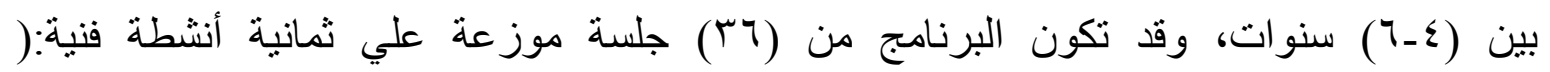

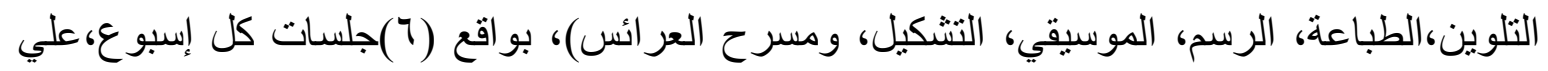

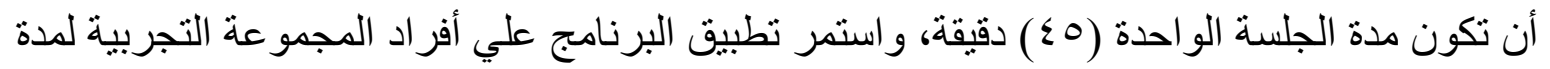

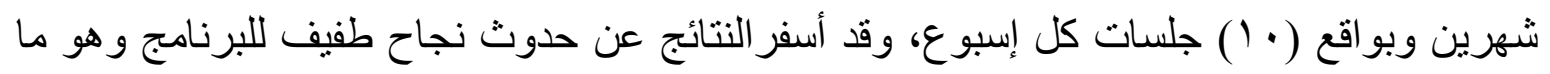
أعزته الباحثة إلي قلة عدد الأنشطة الفنية وتنويعها، و الإعتماد علي فنيات تعديل السلوك.

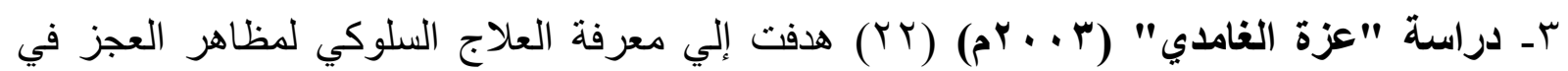

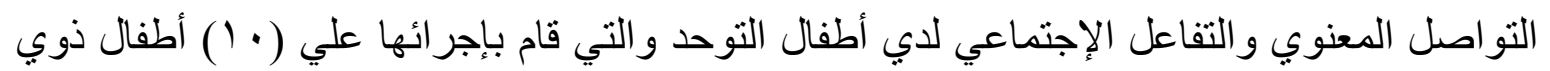

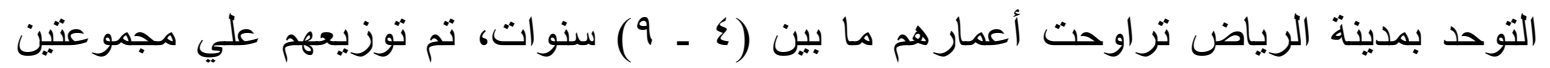
إحداهما تجريبية والأخري ضابطة متكافئتين في العمر والذكاء اللفظي ودرجة التوحد ودرجة العجز

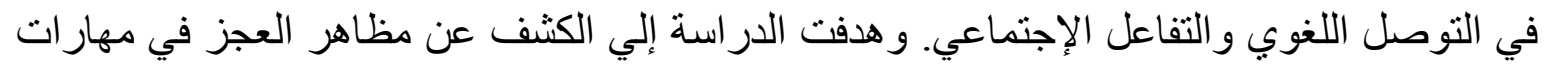
التواصل اللغوي، و الكثف عن مظاهر العجز في مهار ات التفاعل الإجتماعي ،وبعد تطبيق البرنامج

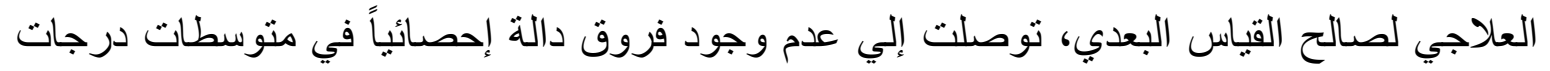

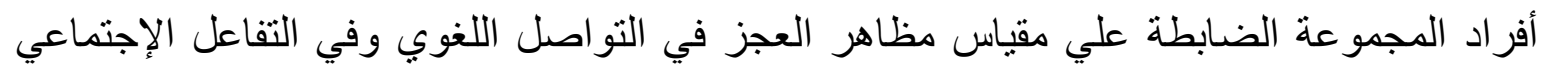
لأطفال التوحد قبل وبعد تطبيق البرنامج.

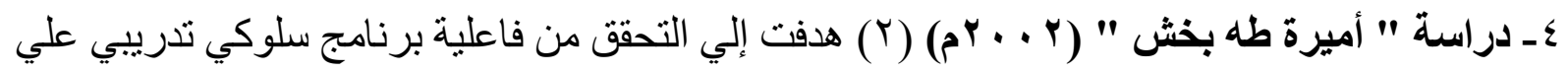
مجموعة من الأطفال ذوي التوحد لتنمية مهار ات تفاعلهم الإجتماعي وخفض سلون بلوكهم العدواني، وقد

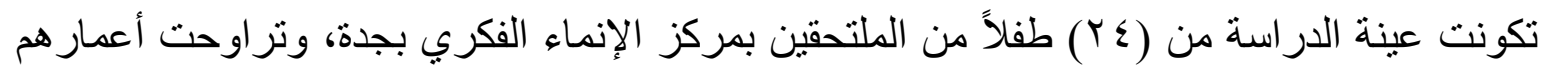

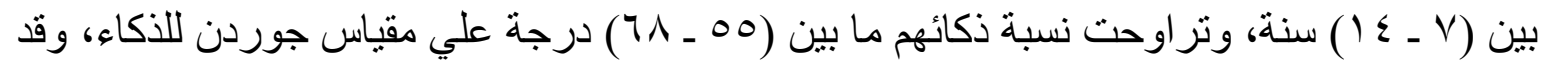

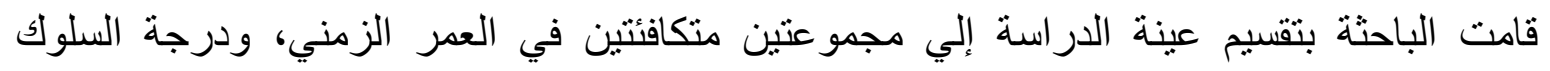
العدواني لاي عينة الدراسة، حيث وجدت فروق ذات دلالة إحصائية بين متوسطات درجات

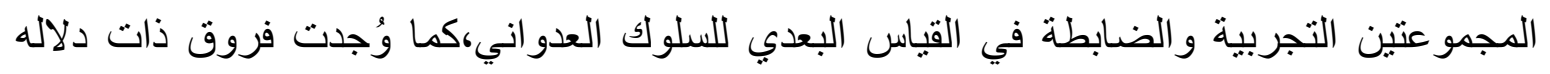
إحصائية بين منوسطي درجات المجموعة التجربية في القياسين القبلي والبعدي للسلوك العدواني و أبعاده.

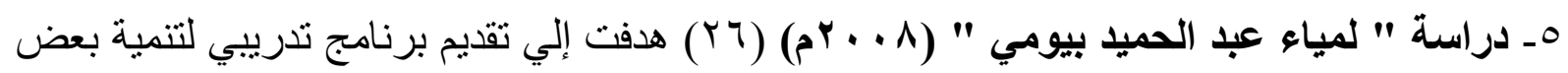

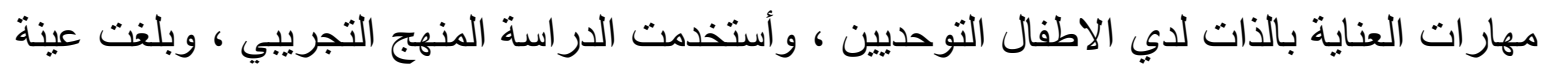

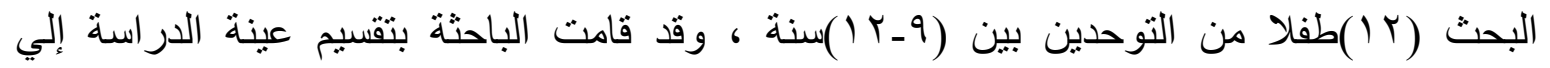

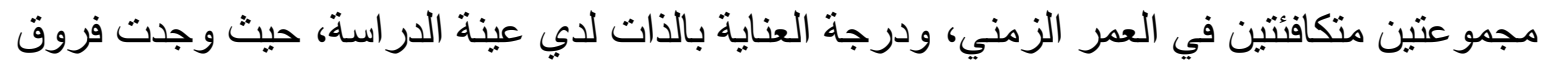
ذات دلالة إحصائية بين منوسطات درجات المجمو عتين التجربية والضابطة في القياس البعدي للعناية بالذات ،كما وُجدت فروق ذات دلاله إحصائية بين متوسطي درجات المجموعة التجربية في القياسين القبلي و البعدي للعناية بالذات.

مجلة بحوث التربية الثاملة ـ كلية التربية الرياضية للبنات - جامعة الزقازيق ـ المجلد الأول ـ للنصف الثاني للابحاث العلمية _ V + Yم 


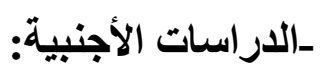

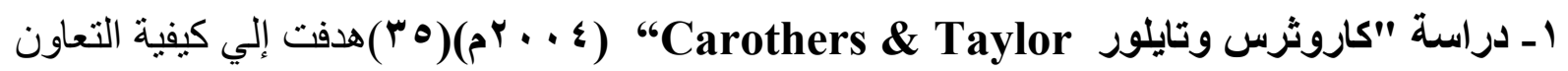

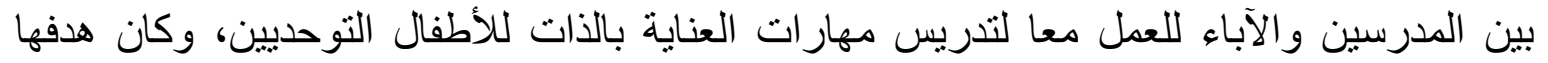

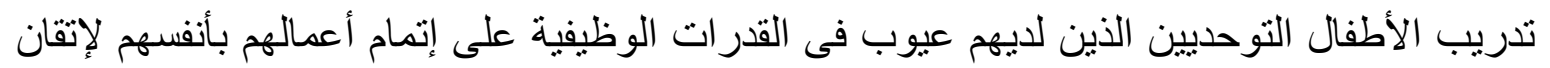

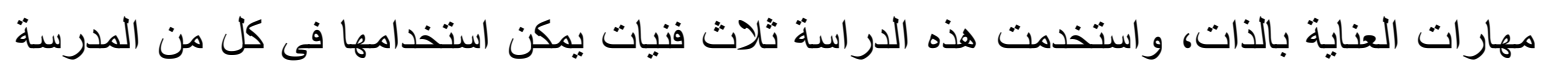

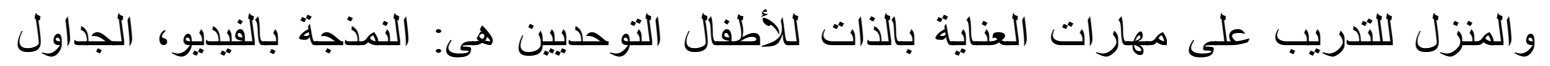

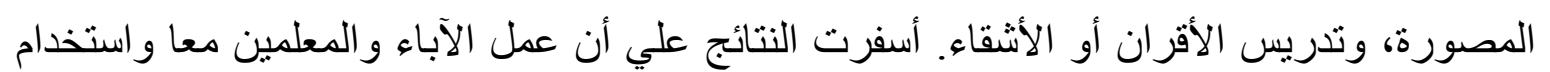

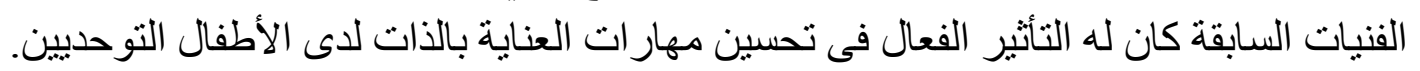

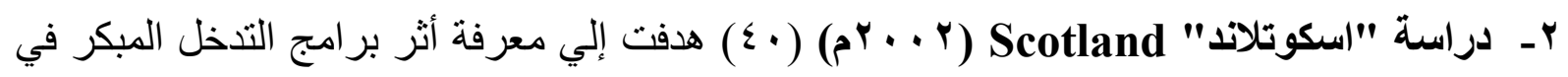

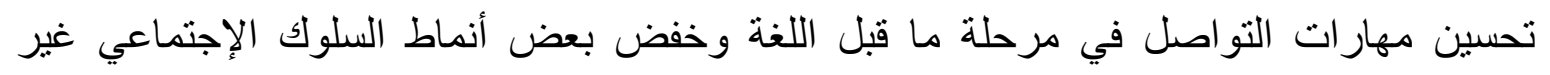

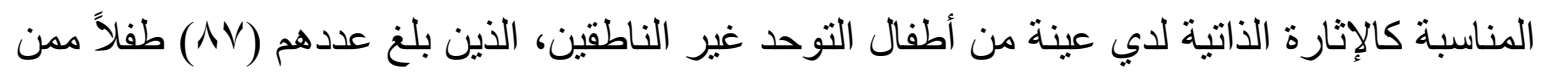

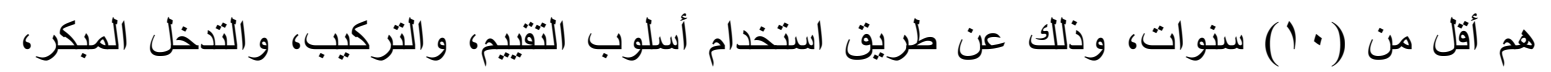

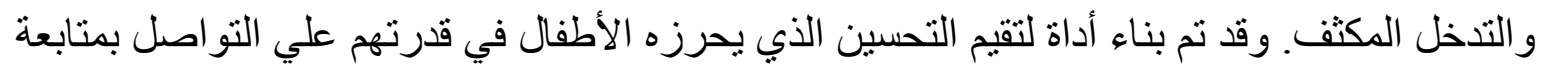

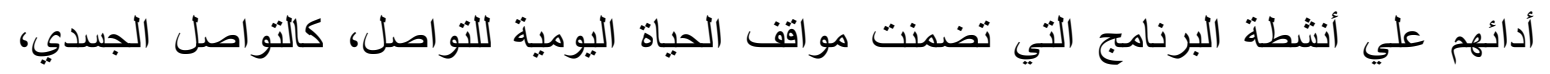

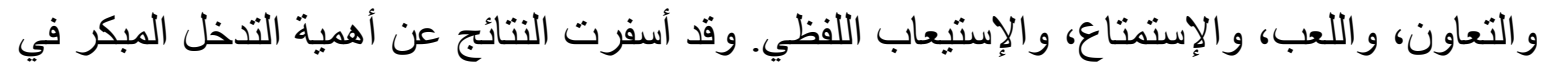

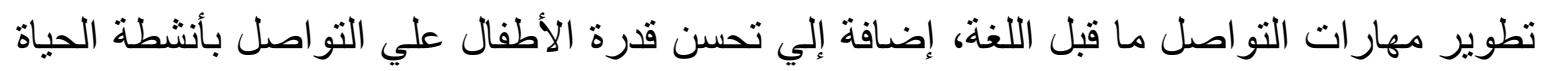

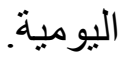

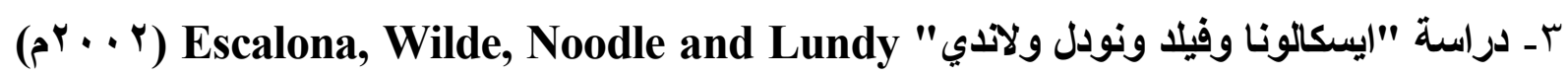

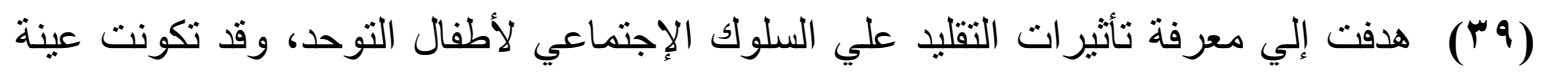

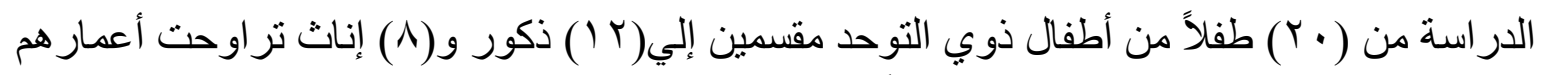

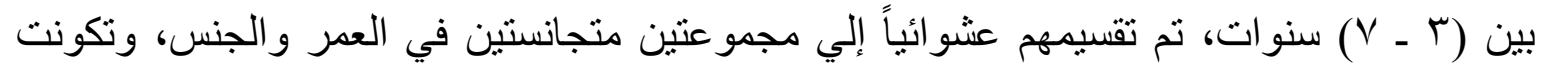

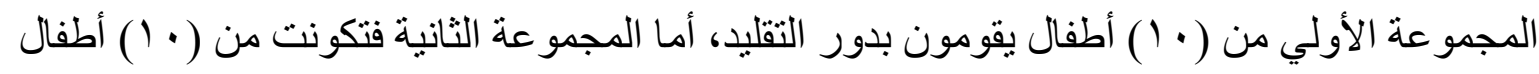

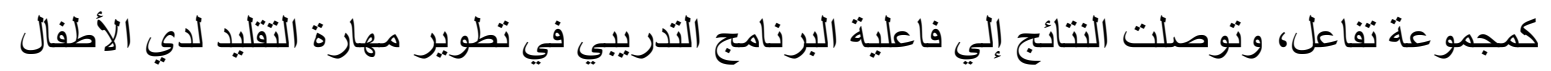

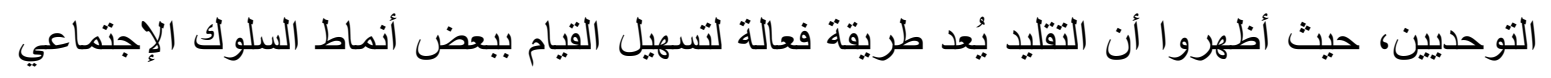

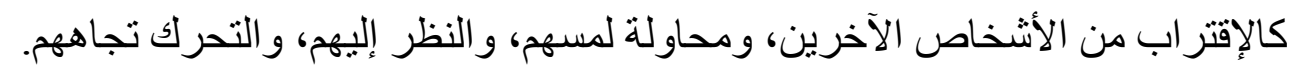

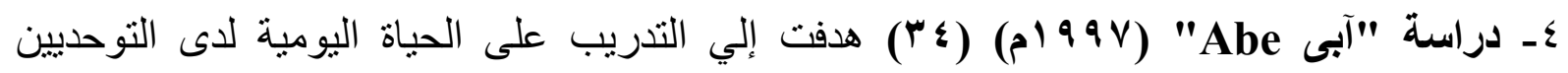

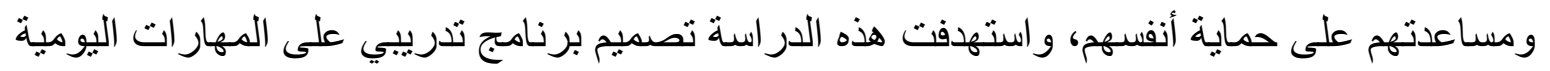

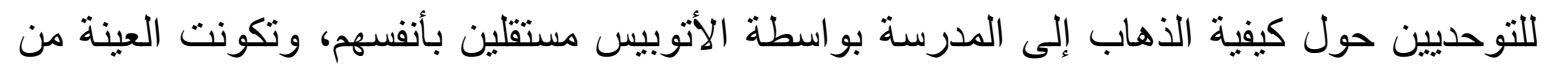

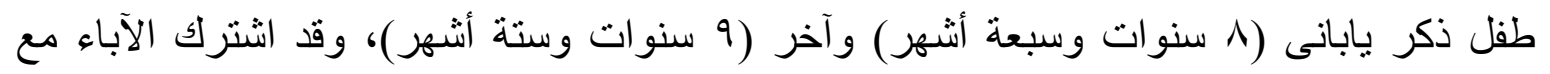

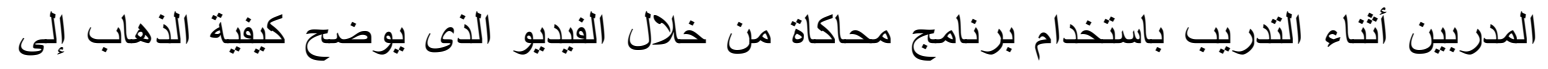

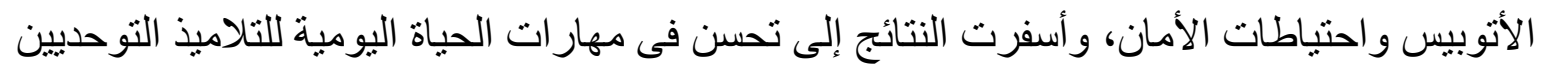
حول كيفية الذهاب إلى المدرسة.

مجلة بحوث التربية الثاملة ـ كلية التربية الرياضية للبنات - جامعة الزقازيق ـ المجلد الأول ـ للنصف الثاني للابحاث العلمية _ V + Yم 
التعليق علي الاراسات المرتبطة:

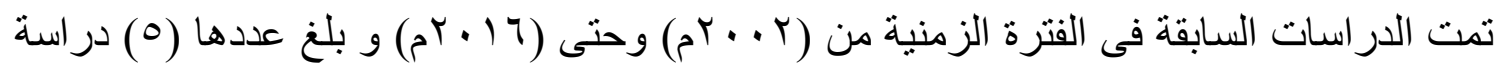
عربية و(ع) دراسة أجنبية وتركزت أهداف الدراسات على معرفة البرامج المناسبة للتوحديين،

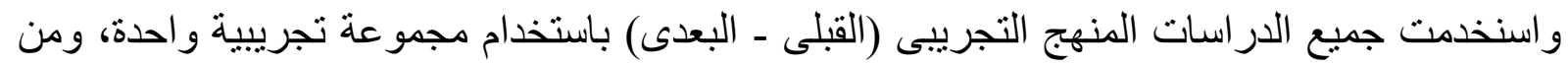

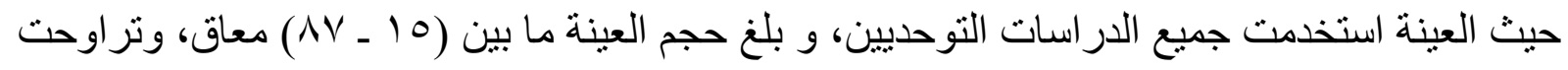

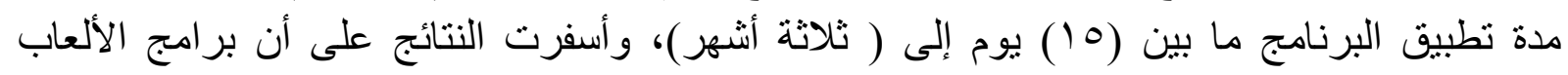

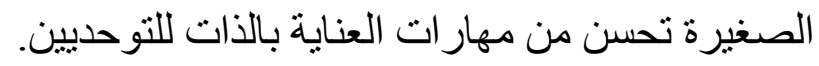

إجراعات البحث:

أولاً : منهج البحث:

إستخدمت الباحثة المنهج التجريبى باستخدام القياس القبلي البعدي لمجموعة واحدة تجريبية حيث

أنها تختبر فعالية برنامج مقتر ح بالألعاب لتنمية مهار ات العناية بالذات لدي الأطفال التوحديين.

ثانيا: عينة البحث:

اـ العينة الاستطلاعية: تم إجراء الدراسة استطلاعية في الفترة الزمنية من

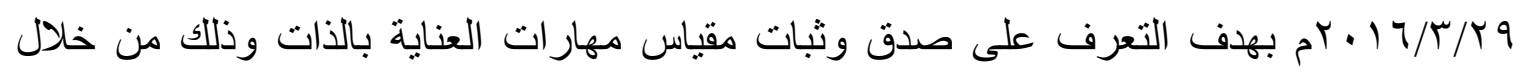

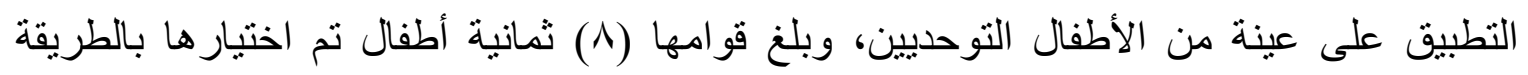
العمدية من "مدرسة التربية الفكرية" بالعباسية، و "مؤسسة السندس للائنة فينام المعاقين" بمدينة نصر،وقد طبق المقياس بصورة فردية من خلال الأخصائية النفسية وأمهات الأطفال التوحديين فى مئية

وجود الباحثة.

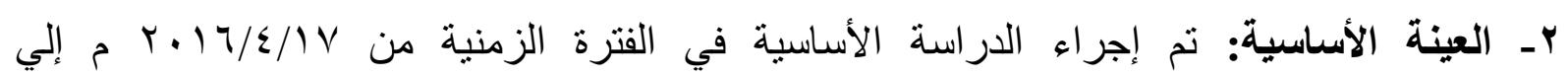

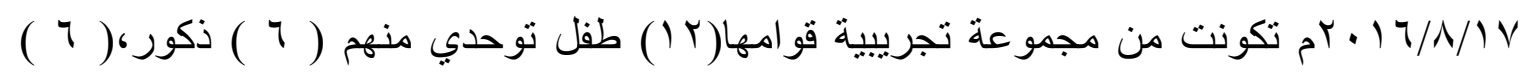

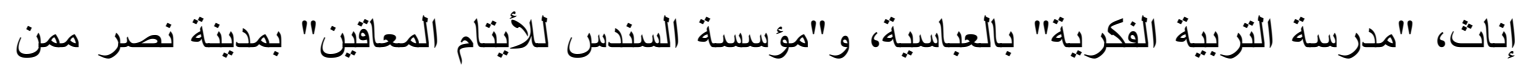

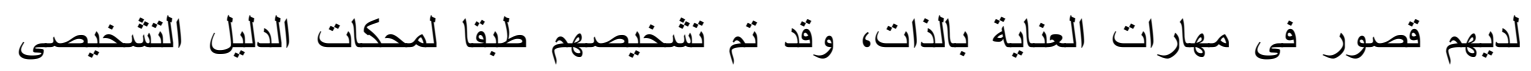
و الإحصائى الر ابع للإضطر ابات العقلية، وهم من فئة متوسطى الإعاقة، وتتر اوح نسبة ذكائهح بين

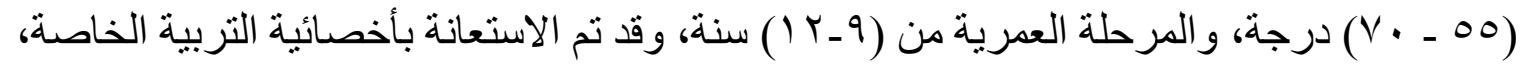

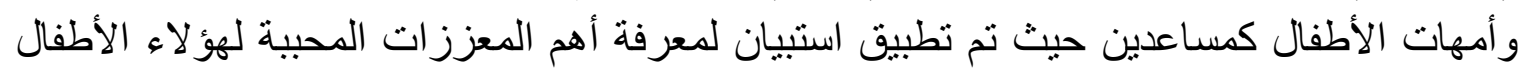

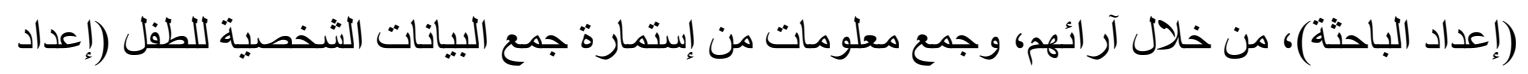

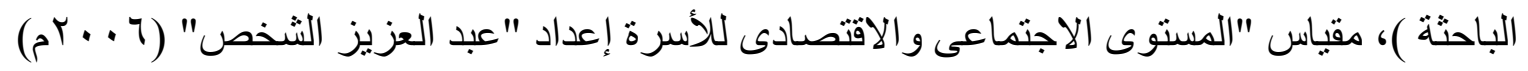

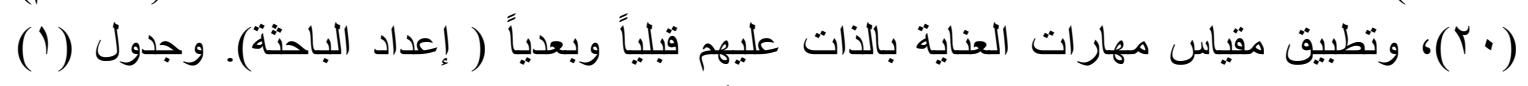

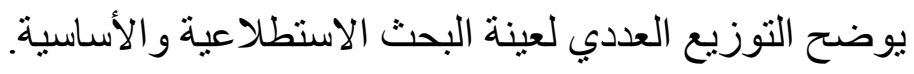

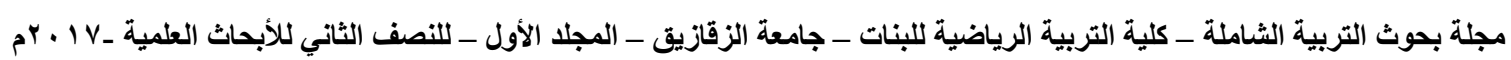




\section{جدول (1)}

التوزيع العددي لعينة البحث الأساسية والاستطلاعية

\begin{tabular}{|c|c|c|c|}
\hline النسبة المئوية & العدد & نوع العينة & p \\
\hline$\%$ \% & $\Lambda$ & الاستطلاعية & 1 \\
\hline$\% 4$ & Ir & الأساسية & r \\
\hline$\% 1 \ldots$ & $r$. & مـوع & \\
\hline
\end{tabular}

يتضح من جدول ( () التوزيع العددي لعينة البحث، وقد بلغت العينة الاستطلاعية للبحث (^) أطفال من داخل مجتمع البحث، وخارج العينة الأساسية، بنسبة مئوية ــ؛

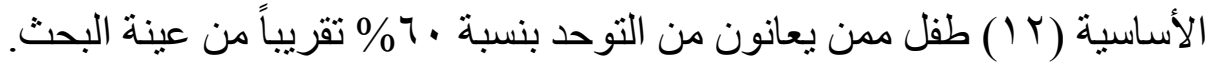
ـ التوصيف الإحصائي لعينة البحث الأساسية في المتغيرات التالية: ـ العمر الزمنى: جميع الأطفال عينة الدراسة يمثلون مرحلة عمرية واحدة وهى الألئه مرحلة الطفولة المتأخرة

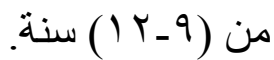

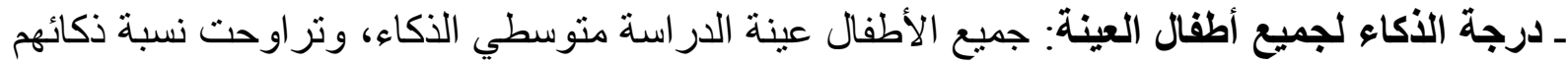

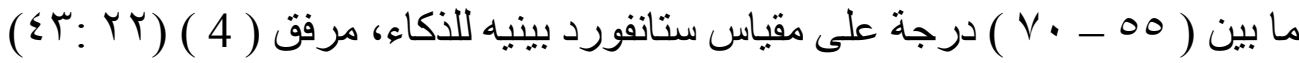

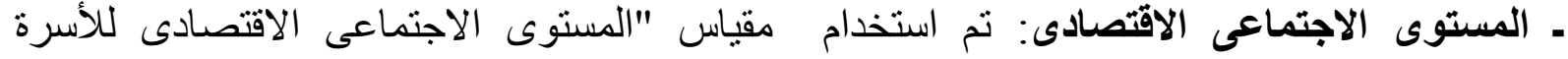

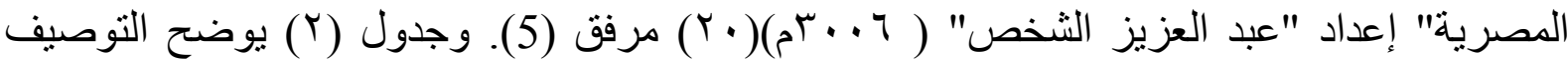
الإحصائي لعينة البحث في المتغير ات قيد الدر اسة.

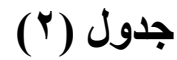

\begin{tabular}{|c|c|c|c|c|c|c|}
\hline الالتو اء & الانحر اف المعيارى & الحسابى الحسط & الوسيط & القياس & المتغيرات & r \\
\hline ·, VAץ & $\cdot, \varepsilon \cdot V$ & $1 \cdot, \wedge Y \wedge$ & $1 \cdot, \Lambda$ & سنة & العمر & 1 \\
\hline$\cdot, Y \cdot V$ & $9, Y \cdot Y$ & $110,0 \mathrm{VI}$ & $1 \% 0$ & سنتيمتر & الطول & $T$ \\
\hline., 940 & $1, .99$ & $\varepsilon r, T \leqslant r$ & $\varepsilon r$ & كيلوجر ام & الوزن & $r$ \\
\hline •, VOY_ & $r, \cdot 1 r$ & $7 \cdot, \wedge \circ \mathrm{V}$ & 7. & درجة & 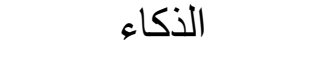 & 0 \\
\hline., 017 & $r, .19$ & $1 \cdot, 0 \leqslant 1$ & $1 \cdot$ & درجة & المستوي الاجتماعي & 7 \\
\hline$\cdot, 907$ & $0, Y \cdot q$ & $10 ., 10 \mathrm{~V}$ & lor,. & درجة & الاختبار الهندي & $\varepsilon$ \\
\hline
\end{tabular}

مجلة بحوث التربية الثاملة ـ كلية التربية الرياضية للبنات - جامعة الزقازيق ـ المجلد الأول ـ للنصف الثاني للأبحاث العلمية _ V ب Y م 
يتضح من جدول (Y) قيم الوسيط، المتوسط الحسابي،الانحر اف المعيارى، ومعامل الالتواء في

متغير ات السن، الطول، الوزن، نسبة الذكاء، المستوي الاجتماعي، ودرجة التوحد لدي عينة البحث

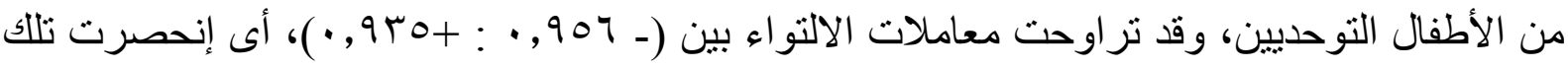

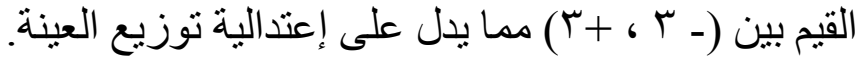
ثالثا: الأدوات المستخدمة :استخدمت الباحثة الأدوات التاع التالية: ا ـ إستطلاع رأي الخبراء و المتخصصين في مجال علم النفس الرياضي، و الفئات الخاصة.

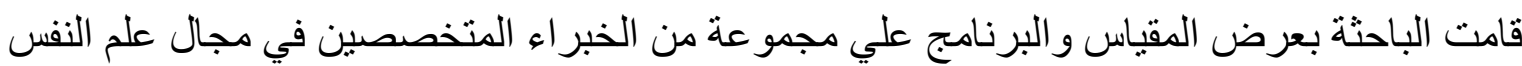

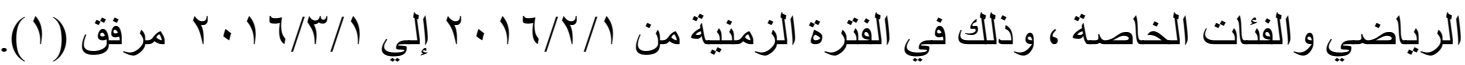
rـ استمارة لجمع البيانات الثخصية لمعرفة أصعب مهارات العناية بالذات لاى الأطفال التوحديين

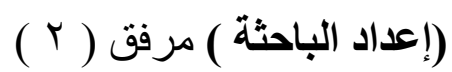
حيث تهدف الاستمارة إلى جمع البيانات الثخصية عن الطفل التوحدى (عينة الدر اسة) و أسرته وذللك للاستفادة من المعلومات في مقياس المستوى الاجتماعى والاقتصادى، وقد تم جمع هذه المعلومات من

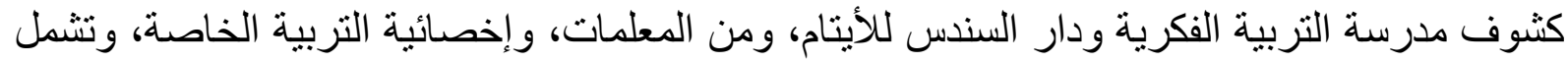

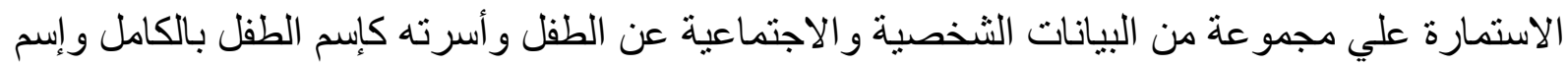

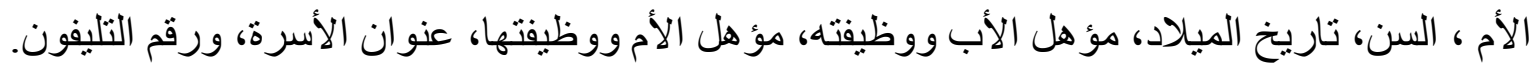

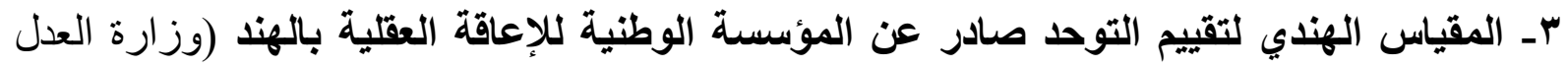

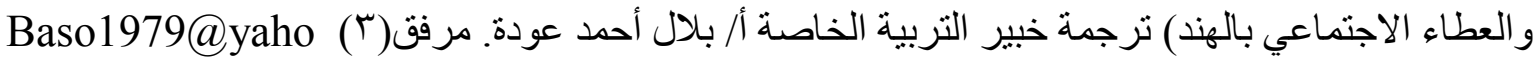

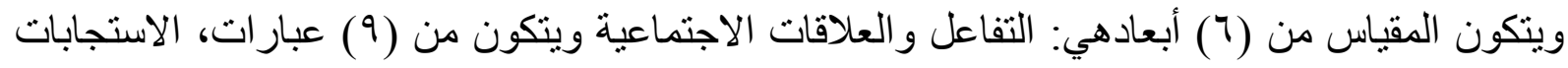

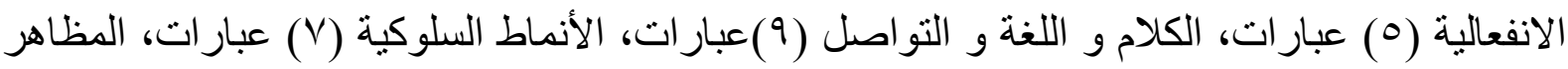

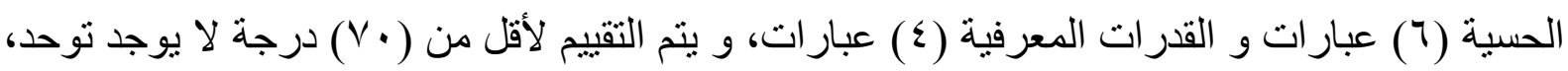

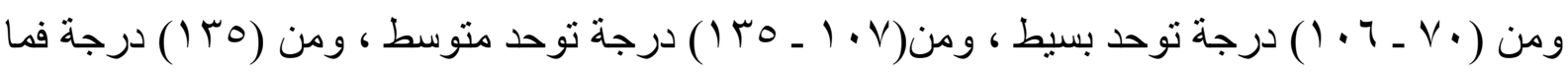
فوق توحد شديد. ع- إختبار الانتباه "لاستانفورد بينيه" الصورة الرابعة تعريب "لويس كامل مليكه" (^و9 (م). مرفق

يستخدم مقياس ستانفورد بينيه للذكاء لقياس وتقييم القدرات العقلية، ونسبة الذكاء، .ويحتوى على مجموعة كبيرة من المهام المعرفية التى تتبئ بالعامل العام للذكاء. وقد قامت الأخصائية النفسية بتطبيق المقياس على الأطفال التوحديين، ونظر الوجود لونئ صعوبة فى

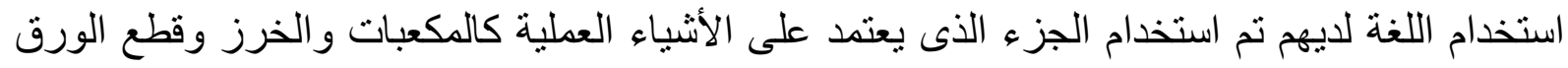

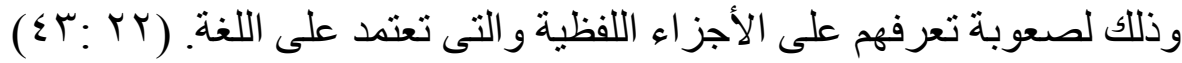

ــ استبيان تقدير المستوى الاجتماعى الاقتصادى للأسرة المصرية. إعداد "عبد العزيز الشخصدية

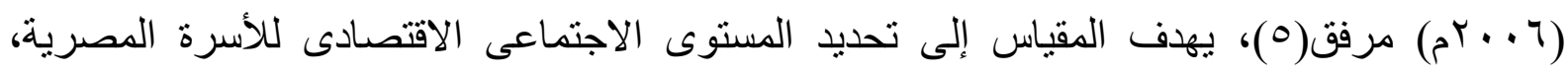
ويحتوى المقياس للأسرة (Y I ) سؤ ال نسطيع من خلاله معرفة المستوي الاجتماعي و الاقتصادي للطفل، وقامت الأخصائية النفسية بتطبيق المقياس علي الأطفال عينة البحث.

مجلة بحوث التربية الثاملة ـ كلية التربية الرياضية للبنات - جامعة الزقازيق ـ المجلد الأول ـ للنصف الثاني للأبحاث العلمية _ V ـ rم 


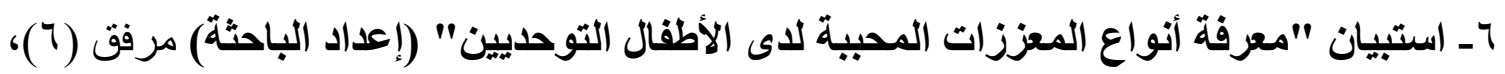

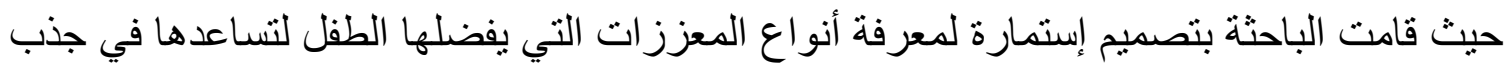

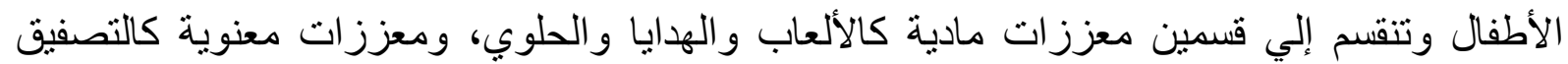

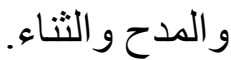

V- مقياس لتقييم مهارات العناية بالذات لأى الأطفال التوحديين (إعداد الباحثة) مرفق ( • (1).

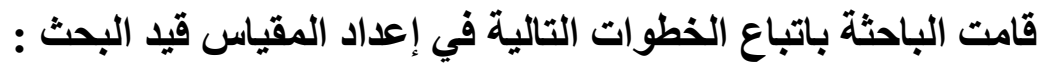

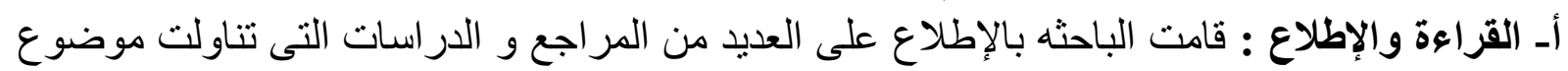

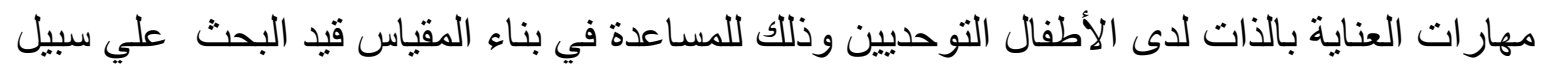

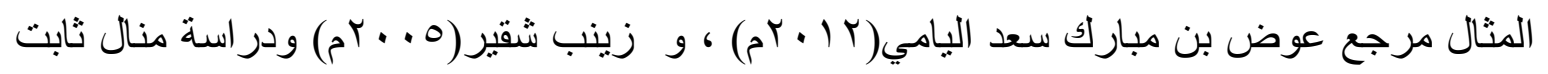

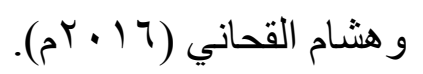

ب ـ تحديد الهذف من المقياس : يهدف المقياس إلى تقييم مهار ات العناية بالذات لدى الأطفال التوحديين

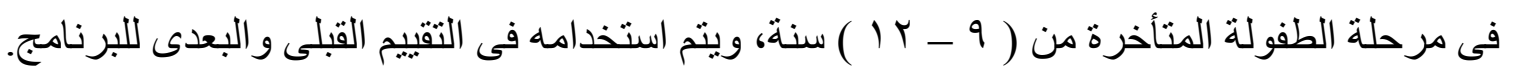

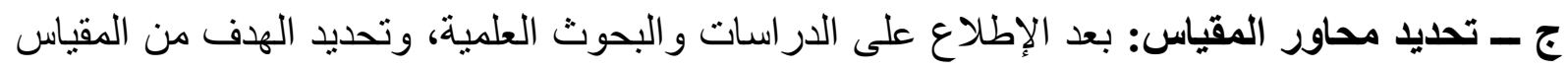

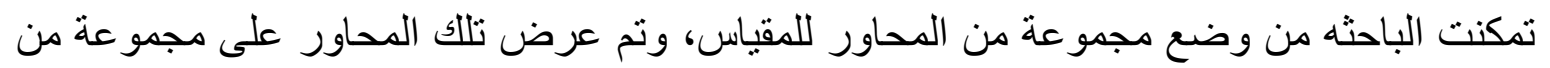

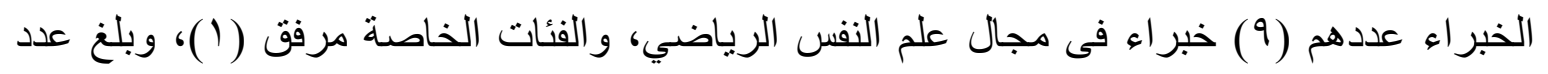

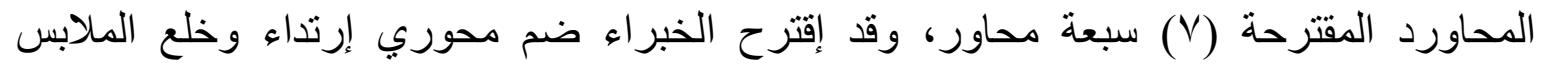

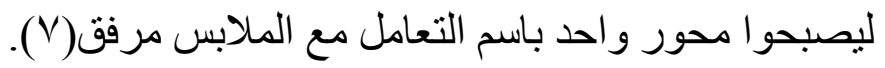

شروط إختيار الخبير:

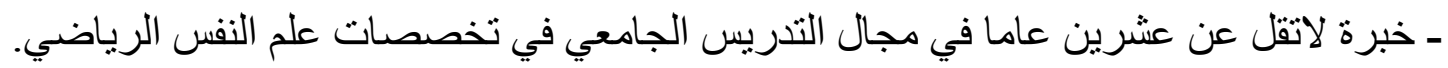

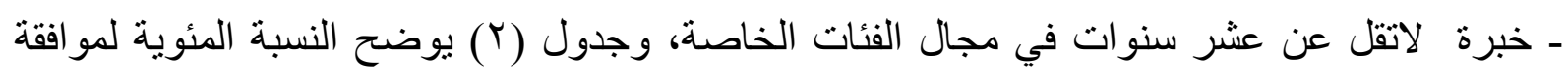
الخبر اء علي تلك المحاور.

$$
\text { جدول (r) (ب) }
$$

$(9=\dot{0})$

النسبة المئوية لموافقة الخبراء على محاورالمقياس قيد البحث

\begin{tabular}{|c|c|c|c|c|}
\hline الترتيب & نسب المو افقة & التكر ار & محاور المقياس & r \\
\hline 1 & $\% 1 \ldots$ & 9 & التعامل مع الطعام & الأول \\
\hline r & $\% 1 \ldots$ & 9 & التعامل مع الثر اب & الثانى \\
\hline$r$ & $\% 1 \ldots$ & 9 & ارتداء الملابس & 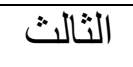 \\
\hline$\varepsilon$ & $\% \wedge \wedge, \wedge q$ & $\Lambda$ & خلع الملابس & الر ابع \\
\hline 0 & $\% \wedge \wedge, \wedge q$ & $\Lambda$ & قضاء الحاجة & الخامس \\
\hline 7 & $\% \vee \vee, \vee \wedge$ & V & النظافة الثخصية & السادس \\
\hline V & $\% \vee \vee, \vee \wedge$ & V & الإحساس بالأمان & السابع \\
\hline
\end{tabular}

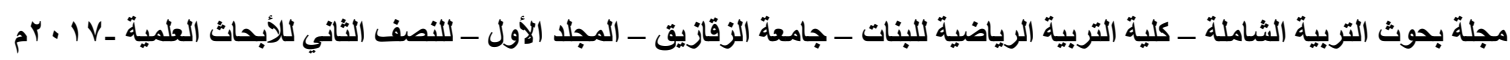




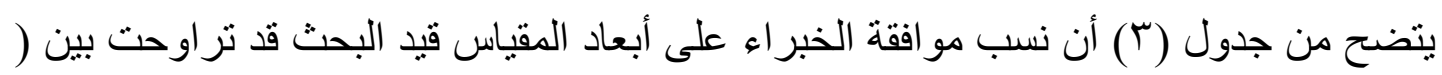

\% \% \%,VA المو افقة علي جميع المحاور وبذلك يكون المقياس قيد البحث مكون من سبعة محاور وهى (التعامل مع

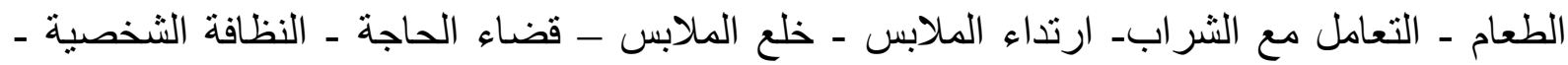

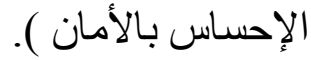

دـ صياغة عبارات المقياس: قامت الباحثه بوضع مجمو عة من العبار ات للمقياس التي تعبر عن المحاور

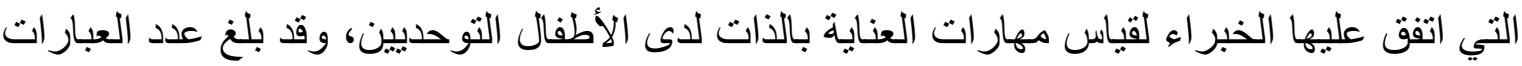

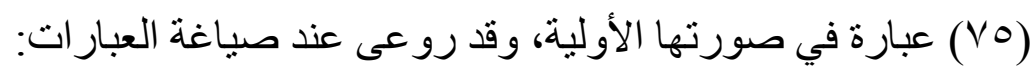

$$
\text { ـ ـ أن يكون للعبارة معنى و احد محدد. }
$$

ـ تجنب استعمال الكلمات التى تحمل أكثر من معنى.

هـ ـ الصورة الأولية للمقياس: تم عرض في صورته الأولية علي الخبر اء السابق ذكر هم و عدده (V0)

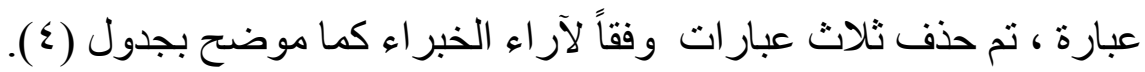

\begin{tabular}{|c|c|c|c|c|}
\hline بعد الحذف العبارات & أرقام العبار المحذوفة & عدد العبارات & عدد العبارات فى & المقياس \\
\hline VY & $r_{r_{6}} \leqslant r_{6} 0 T$ & $\mu$ & vo & لدى الأطفال التوحديين العناية بالذات \\
\hline
\end{tabular}

$$
\text { جدول ( ) }
$$

الصورة الأولية للمقياس

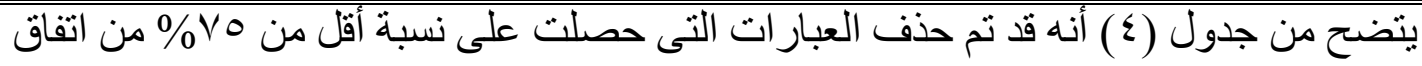

وقد بلغ عدد العبار ات المحذوفة (r) عبار ات، وبذلك أصبح عدد عبار ات المقياس (VY) عبارة تمهيداً لإجر اء المعاملات العلمية لحساب ( صدق وثبات ) المقياس قبد البحث علي عينة البحث الاستطلاعية،

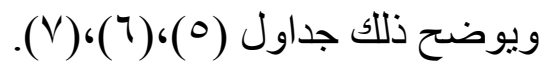

مجلة بحوث التربية الثاملة ـ كلية التربية الرياضية للبنات - جامعة الزقازيق ـ المجلد الأول ـ للنصف الثاني للأبحاث العلمية _ V ـ rم 
رابعاً: المعاملات العلمية للمقياس قيد البحث:

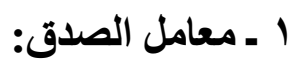

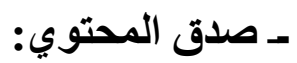

قامت الباحثة بحساب صدق المحتوى من خلال عرض محاور المقياس على (9) من الخبراء

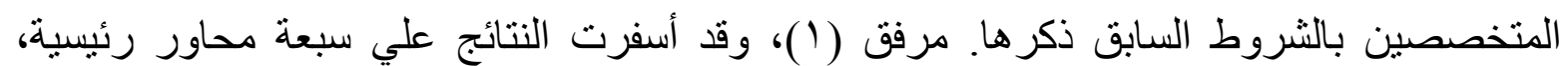

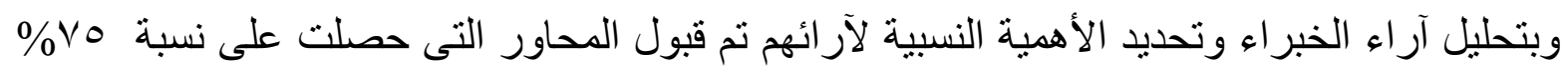

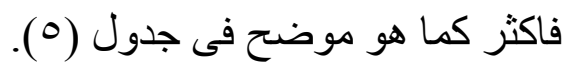

(0) جدول

النسبة المئوية لآراء الخبراء حول محاور المقياس ( ن = 9 )

\begin{tabular}{|c|c|c|}
\hline 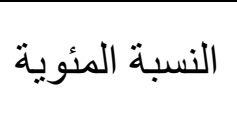 & الخبر آء & المحــــــاور \\
\hline$\% 1 \cdots$ & 9 & المحور الأول : التعامل مع الطعام ويقيس (10 ) عبارة \\
\hline$\% \wedge \wedge, \wedge 9$ & $\wedge$ & الدحور الثاني : التعامل مع الثراب و يقيس (†) عبار ات . \\
\hline$\% 1 \cdots$ & 9 & المحور الثالث : التعامل مع الملابس ويقيس (؟Y) عبارة . \\
\hline$\% \wedge \wedge, \wedge 9$ & $\Lambda$ & المحور الر ابع: قضاء الحاجة ويقيس (†) عبار ات . \\
\hline$\% 1 \cdots$ & 9 & الدحور الخامس: النظافة الثخصية ويقيس (^) عبار ات . \\
\hline$\% 1 \ldots$ & 9 & الدحور السادس: الإحساس بالأمان ويقيس (r I ) عبارة . \\
\hline \multicolumn{3}{|c|}{ يتضح من جدول (0) النسبة المئوية لكل محوروفقا لآراء الخبر اء، وقد إرتضت الباحثه با لمحاور } \\
\hline
\end{tabular}

مجلة بحوث التربية الثاملة ـ كلية التربية الرياضية للبنات - جامعة الزقازيق ـ المجلد الأول ـ للنصف الثاني للأبحاث العلمية _ V ـ rم 


\section{جدول (†)}

النسبة المئوية لآراء الخبراء حول عبارات كل محور من محاور المقياس قيل البحث (ن=9 )

\begin{tabular}{|c|c|c|c|}
\hline المئوية & $\begin{array}{c}\text { آلخبر اءء } \\
\text { آراء }\end{array}$ & 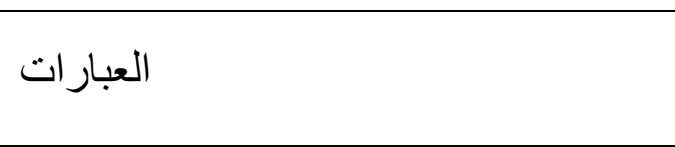 & r \\
\hline \multicolumn{4}{|c|}{ المحور الأول : التعامل مع الطعام } \\
\hline$\% 1 \ldots$ & 9 & يتذوق أنواع الطعام المختلفة. & $r$ \\
\hline$\% \%^{\wedge \wedge, \wedge ৭}$ & $\Lambda$ & يعرف نوعية الاكل من ر ائحته وملمسه. & $\varepsilon$ \\
\hline$\% \wedge \wedge, \wedge 9$ & $\wedge$ & يطلب نو عية معينة من الطعام. & 0 \\
\hline$\% 1 \cdots$ & 9 & يستطيع مسك الطعام بمفرده دون مساعده. & 19 \\
\hline$\% 1 \ldots$ & 9 & يعرف الطعام الصلب من اللين. & Y) \\
\hline$\% 1 \cdots$ & 9 & يفضل أن تطعمده الأم بفمه. & Tr \\
\hline$\% 1 \ldots$ & 9 & يقدر على مسك الملعقة بدون مساعدة. & $r r$ \\
\hline$\% \wedge \wedge, \wedge \uparrow$ & $\wedge$ & يبلع الطعام بسهولة ويسر. & TV \\
\hline$\% 1 \cdots$ & 9 & يكره إستخدام أدوات المائدة بمفرده. & rᄉ \\
\hline$\% 1 \cdots$ & 9 & يستطيع مسك أدو ات المائدة بمفرده. & rq \\
\hline$\% \wedge \wedge, \wedge \uparrow$ & $\wedge$ & يحب أن يأكل في أب وقت. & $\varepsilon$ \\
\hline$\% \wedge \wedge, \wedge 9$ & $\Lambda$ & يحب الاكلات الساخنة أكثر من الباردة. & $\varepsilon V$ \\
\hline$\% \wedge \wedge, \wedge 9$ & $\Lambda$ & يستمتع بأكل الفاكهة الطازجة. & 71 \\
\hline$\% 1 \ldots$ & 9 & يفضل مسك السندونش بيده. & 79 \\
\hline$\% 1 \cdots$ & 9 & يأكل أي كمية من الطعام الدقدمة إليه. & VY \\
\hline \multicolumn{4}{|c|}{ المحور الثاني : التعامل مع الثراب } \\
\hline$\% \wedge \wedge, \wedge 9$ & $\wedge$ & يحب المشروبات الساخنة. & 14 \\
\hline$\% 1 \cdots$ & 9 & يكره العصائر الباردة والمثلجة. & $1 \leq$ \\
\hline$\% 1 \cdots$ & 9 & يصب بنفسه من الزجاجة إلى الكوب. & 10 \\
\hline$\% \wedge \wedge, \wedge 9$ & $\wedge$ & يفرق بين المياه وباقى المشروبات. & 17 \\
\hline$\% 1 \cdots$ & 9 & يقوم بفتح الزجاجة بسهولة ويسر. & IV \\
\hline$\% 1 \cdots$ & 9 & يقدر علي ملاً الكوب بنفسه دون مساعدة. & 11 \\
\hline \multicolumn{4}{|c|}{ المحور الثالث : التعامل مع الملابس. } \\
\hline$\% \wedge \wedge, \wedge 9$ & $\Lambda$ & يعرف الفرق بين البنطال و الثورت. & 1. \\
\hline$\% 1 \cdots$ & 9 & يستطيع معرفة يمين ويسار الحذاء. & $T V$ \\
\hline$\% 1 \cdots$ & 9 & يقل سوستة البنطال بسهولة. & rA \\
\hline$\% 1 \cdots$ & 9 & يلبس فردني الحذاء بنظام. & rq \\
\hline
\end{tabular}

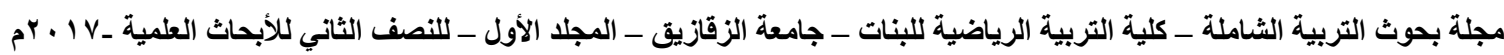




\begin{tabular}{|c|c|c|c|}
\hline$\% 1 \cdots$ & 9 & يفرق بين الجور اب و الكلوك. & $\leqslant r$ \\
\hline$\% \wedge \wedge, \wedge q$ & $\Lambda$ & يفرق بين فردتي الحذاء. & or \\
\hline$\% 1 \ldots$ & 9 & يحب ارتداءالملابس بدون زر اير او سوستة. & or \\
\hline$\% 1 \ldots$ & 9 & يفضل لبس الجاكت عن البلوفر. & 74 \\
\hline$\% 1 \cdots$ & 9 & يفضل ارتداء القبعة علي راسه. & $\pi r$ \\
\hline$\% 1 \cdots$ & 9 & يخلع حذائه بمفرده دون مساعدة. & 11 \\
\hline$\% \wedge \wedge, \wedge q$ & $\wedge$ & يصعب عليه خلع الفانلة بمفرده. & ir \\
\hline$\% 1 \cdots$ & 9 & يقطع الفانلة عند خلعها بمفرده. & 14 \\
\hline$\% 1 \cdots$ & 9 & يمزق جميع الملابس عند خلعها. & $r$ \\
\hline$\% 1 \cdots$ & 9 & يفلك زر اير القميص بسهولة ويسر. & M \\
\hline$\% 1 \cdots$ & 9 & يقدر علي خلع الملابس الداخلية. & rt \\
\hline$\% 1 \cdots$ & 9 & يقدر على خلع التيشيرت ببساطة. & $\varepsilon r$ \\
\hline$\% 1 \cdots$ & 9 & يقطع الملابس عند خلعها. & $\leqslant \varepsilon$ \\
\hline$\% 1 \cdots$ & 9 & يجد صعوبة أثناء خلع ملابسـه. & $\leqslant 0$ \\
\hline$\% 1 \cdots$ & 9 & يصعب عليه خلع الحذاء بمفرده. & $\varepsilon 7$ \\
\hline$\% \wedge \wedge, \wedge q$ & $\wedge$ & يخر ج رأسه من الملابس ببساطة. & $0 \leqslant$ \\
\hline$\% \wedge \wedge, \wedge q$ & $\wedge$ & يخلع ملابسـه بنفسه داخل الحمام. & 09 \\
\hline$\% 1 \cdots$ & 9 & يخلع غطاء الر أس أو لا ببساطةً. & $7 \varepsilon$ \\
\hline$\% 1 \cdots$ & 9 & يقدر على خلع الأكمام بسهولة. & 70 \\
\hline$\% 1 \cdots$ & 9 & يصعب عليه فلك أزرار أكمام الجاكت. & 77 \\
\hline \multicolumn{4}{|c|}{ المحور الر ابع: قضناء الحاجة. } \\
\hline$\% 1 \cdots$ & 9 & يعانى من التبزر في ملابسه الداخلية. & 7 \\
\hline$\% 1 \cdots$ & 9 & يخلع جميع ملابسة ليتبرز. & $\bar{V}$ \\
\hline$\% 1 \cdots$ & 9 & يعبر بوحهه عن أحتياجه عن قضاء حاجنه. & rT \\
\hline$\% 1 \cdots$ & 9 & يصعب عليه قضاء حاجاته في الحمام. & rs \\
\hline$\% 1 \cdots$ & 9 & يقضي حاجته دون مساعدة الغير. & $\xi 1$ \\
\hline$\% 1 \cdots$ & 9 & تتنابه أعر اض هستيرية عند رغبته في قضاء حاجته. & 01 \\
\hline \multicolumn{4}{|c|}{ المحور الخامس: النظافة الشخصية } \\
\hline$\% 1 \cdots$ & 9 & يخاف من غسل وجهه بالصابون. & 9 \\
\hline$\% 1 \cdots$ & 9 & يحب الاستحمام بالماء و الصابون. & ro \\
\hline$\% 1 \cdots$ & 9 & يحب غسل شعره بالثامبو. & $r q$ \\
\hline
\end{tabular}




\begin{tabular}{|c|c|c|c|}
\hline$\% 1 \cdots$ & 9 & | يرمى المياه على من حوله. & 00 \\
\hline$\% 1 \cdots$ & 9 & يخشى تقليم الأظافربمفرده. & 7 . \\
\hline$\% 1 \cdots$ & 9 & يحب استخدام العطوروكريمات التجميل. & 71 \\
\hline$\% 1 \ldots$ & 9 & يخشى من أستعمال المياه في الثتاء. & V. \\
\hline$\% 1 \cdots$ & 9 & | يحب الاستحمام بمفرده. & V) \\
\hline \multicolumn{4}{|c|}{ المحور السادس: الإحساس بالأمان } \\
\hline$\% 1 \cdots$ & 9 & | يضرب وجهه باليدين بسر عة. & 1 \\
\hline$\% 1 \cdots$ & 9 & | يخاف من الذهاب لزيارة أقاربه. & r \\
\hline$\% \wedge \wedge, \wedge q$ & $\Lambda$ & | يستطيع فتح باب الغرفة بمفرده. & $\wedge$ \\
\hline$\% 1 \cdots$ & 9 & يلعب بالاشياء الخطيرة و الصعبة & 17 \\
\hline$\% \wedge \wedge, \wedge q$ & $\Lambda$ & |يضع الاقلام في عينه وفمه و أذنه & IV \\
\hline$\% 1 \cdots$ & 9 & يريد التو اجد مع الأم او الأب دائما. & 11 \\
\hline$\% 1 \cdots$ & 9 & يكره الحديث مع اخو انه و أمعارفه & $r \cdot$ \\
\hline$\% 1 \cdots$ & 9 & يحب الخروج إلى الحدائق و المنتز هات. & ro \\
\hline$\%$ & 9 & يخشى الذهاب لاى الاصحاب و الاصدقاء & r \\
\hline$\% 1 \cdots$ & 9 & يقدر على اللعب مع زملائه بالمدرسة. & $\leqslant 9$ \\
\hline$\% 1 \cdots$ & 9 & يحب التو اجد فى المنزل مع أمه و أبيه & 0. \\
\hline$\% 1 \cdots$ & 9 & يصر علي النوم كل ليلة بجانب أمه . & OV \\
\hline$\% 1 \cdots$ & 9 & | يخاف من ركوب المصعد . & 01 \\
\hline
\end{tabular}

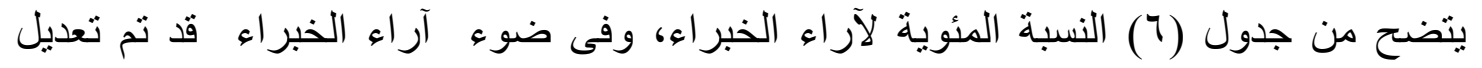

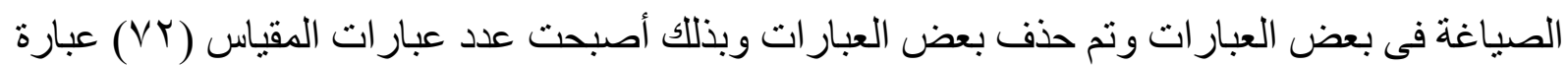

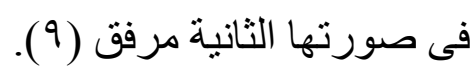

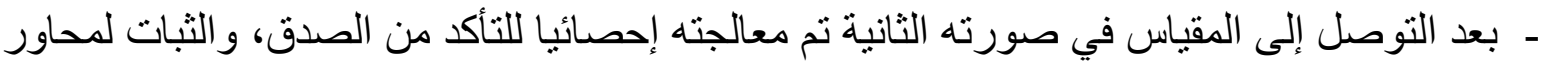

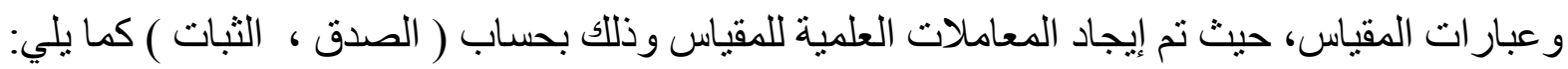
وتم حساب الصدق بطريقتين (صدق المحتوى) جدول (0)،(7)، و (الاتساق الداخلي) جدول (V).

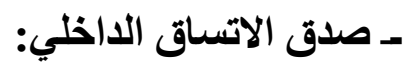

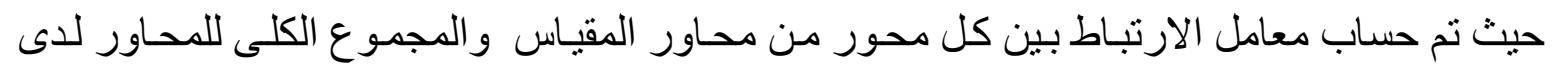

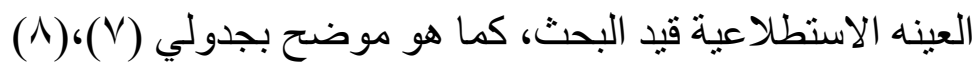


$-\wedge{ }_{-}$

دور الألعاب في تنمية العناية بالذات لذوي الاحتياجات الخاصة

\section{جول ج) (V)}

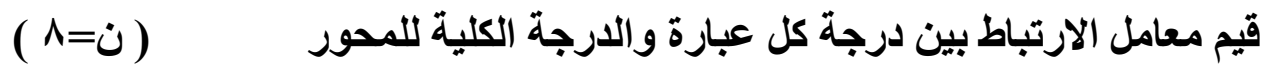

\begin{tabular}{|c|c|c|c|c|c|c|c|}
\hline \multicolumn{2}{|c|}{ الإحساس بالأمان: } & \multicolumn{4}{|c|}{ المحور الثالث : التعامل مع الملابس } & \multicolumn{2}{|c|}{ المحور الأول : التعامل مع } \\
\hline 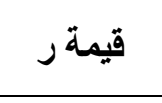 & العبارة & قيمة ر & العبارة & قيمة ر & رقم العبارة & 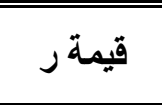 & رقم العبارة \\
\hline $.940(* *)$ & 17 & $.927(* *)$ & 70 & $.745\left(^{*}\right)$ & 1. & $.965(* *)$ & $r$ \\
\hline $.940(* *)$ & IV & $.715(*)$ & 77 & $.915(* *)$ & TV & $.901(* *)$ & $\varepsilon$ \\
\hline $.929(* *)$ & 11 & \multicolumn{2}{|c|}{ المحور الرابع:قضاء } & $.764(*)$ & rA & $.990(* *)$ & 0 \\
\hline $.941(* *)$ & $r \cdot$ & $.913(* *)$ & 7 & $.972(* *)$ & rq & $.990(* *)$ & 19 \\
\hline $.941(* *)$ & ro & $1.000(* *)$ & $\mathrm{V}$ & $.771(*)$ & $\varepsilon Y$ & $.882(* *)$ & Y) \\
\hline $.933(* *)$ & r & $1.000(* *)$ & rT & $.896(* *)$ & or & $.965(* *)$ & rr \\
\hline $.784(*)$ & $\varepsilon 9$ & $1.000(* *)$ & Tร & $.991(* *)$ & or & $.913(* *)$ & r \\
\hline $.784(*)$ & 0. & $.942(* *)$ & §1 & $.972(* *)$ & Tr & $.910(* *)$ & rV \\
\hline $.865(* *)$ & OV & $1.000(* *)$ & 01 & $.907(* *)$ & $4 \pi$ & $.923(* *)$ & rᄉ \\
\hline \multirow[t]{13}{*}{$.786\left(^{*}\right)$} & 01 & \multicolumn{2}{|c|}{ المحور الخامس: النظافة } & $.972(* *)$ & 11 & $.882(* *)$ & rq \\
\hline & & $.959(* *)$ & 9 & $.972(* *)$ & IT & $.923(* *)$ & $\varepsilon$. \\
\hline & & $.959(* *)$ & ro & $.715(*)$ & $\pi$ & $.913(* *)$ & $\varepsilon V$ \\
\hline & & $.936(* *)$ & rt & $.972(* *)$ & $r$ & $.930(* *)$ & 71 \\
\hline & & $.909(* *)$ & 00 & $.991(* *)$ & MI & $.743(*)$ & 79 \\
\hline & & $.909(* *)$ & 7. & $.991(* *)$ & Tr & $.796(*)$ & $V T$ \\
\hline & & $.953(* *)$ & 71 & $.927(* *)$ & rV & كامل مع & المحور الثاند \\
\hline & & $.885(* *)$ & $v$. & $.896(* *)$ & $\varepsilon \varepsilon$ & $.908(* *)$ & $1 T$ \\
\hline & & $.834(*)$ & VI & $.896(* *)$ & $\leqslant 0$ & $.858(* *)$ & $1 \varepsilon$ \\
\hline & & \multicolumn{2}{|c|}{ الإحساس بالأمان: } & $.991(* *)$ & $\leq 7$ & $.908(* *)$ & 10 \\
\hline & & $.940(* *)$ & 1 & $.991(* *)$ & $0 \varepsilon$ & $.936(* *)$ & 17 \\
\hline & & $.851(* *)$ & r & $.896(* *)$ & 09 & $.993(* *)$ & IV \\
\hline & & $.851(* *)$ & $\Lambda$ & $.715(*)$ & $7 \varepsilon$ & $.794(*)$ & 11 \\
\hline
\end{tabular}

قيمة ر الجدولية عند مستوى معنوية 0 ., • هى ( ب T, · )

مجلة بحوث التربية الثاملة ـ كلية التربية الرياضية للبنات - جامعة الزقازيق ـ المجلد الأول ـ للنصف الثاني للأبحاث العلمية _ V . P م 


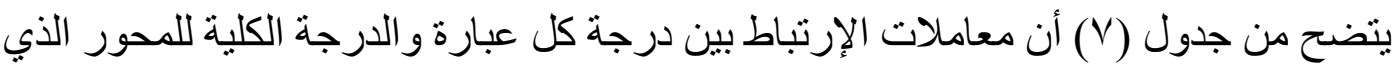
تتنمي إليه ذات دلالة إحصائية، حيث جاءت قيم (ر) المحسوبة أكبر من قيمة (ر) الجدولية ، مما يدل

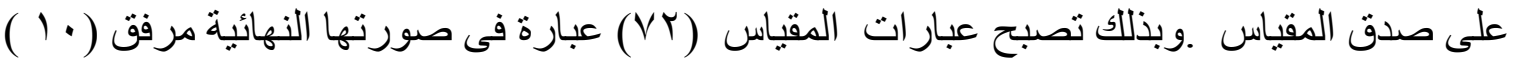

$$
\text { جدول (^) }
$$

قيم معامل الارتباط بين كل محور من محاور

المقياس والمجموع الكلى للمحاور

\begin{tabular}{|c|c|c|c|c|}
\hline معامل الإرتباط & الإنحر افياري & الحستوسطي & 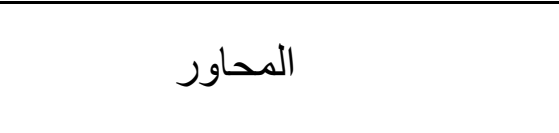 & r \\
\hline $.997(* *)$ & 11.86833 & 33.5000 & المحور الأول : التعامل مع الطعام & 1 \\
\hline $.994(* *)$ & 4.51782 & 13.8750 & المحور الثاني : التعامل مع الثراب & 2 \\
\hline $.999(* *)$ & 20.13481 & 52.6250 & المحور الثالث التعامل مع الملابس & 3 \\
\hline $.970(* *)$ & 5.69304 & 13.8750 & المحور الر ابع: قضاء الحاجة & 4 \\
\hline $.996(* *)$ & 6.76123 & 17.5000 & المحور الخامس: النظافة الشخصية & 5 \\
\hline $.994(* *)$ & 10.79352 & 28.2500 & المحور السادس: الإحساس بالأمان & 6 \\
\hline 1 & 59.42327 & 159.6250 & \multicolumn{2}{|c|}{ المجموع الكلى } \\
\hline
\end{tabular}

يتضح من جدول (^) وجود علاقة ارتباطية ذات دلالة إحصائية بين كل محور من محاور

المقياس و المجموع الكلى للمحاور لدى العينه قبد البحث، مما بدل على صدق الإتساق الداخلى للمقياس قبد البحث.

r ـ ثبات المقياس : بعد التأكد من صدق المقياس تم حساب معاملات الثبات باستخدام معامل ثبات

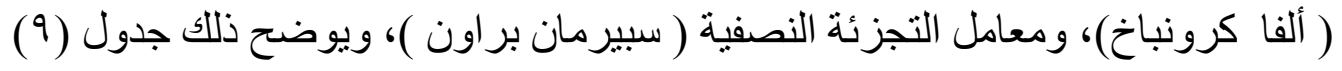

\section{(9) جدول}

معامل ثبات المقياس باستخدام ( ألفا كرونباخ

$$
(\Lambda=\dot{0})
$$

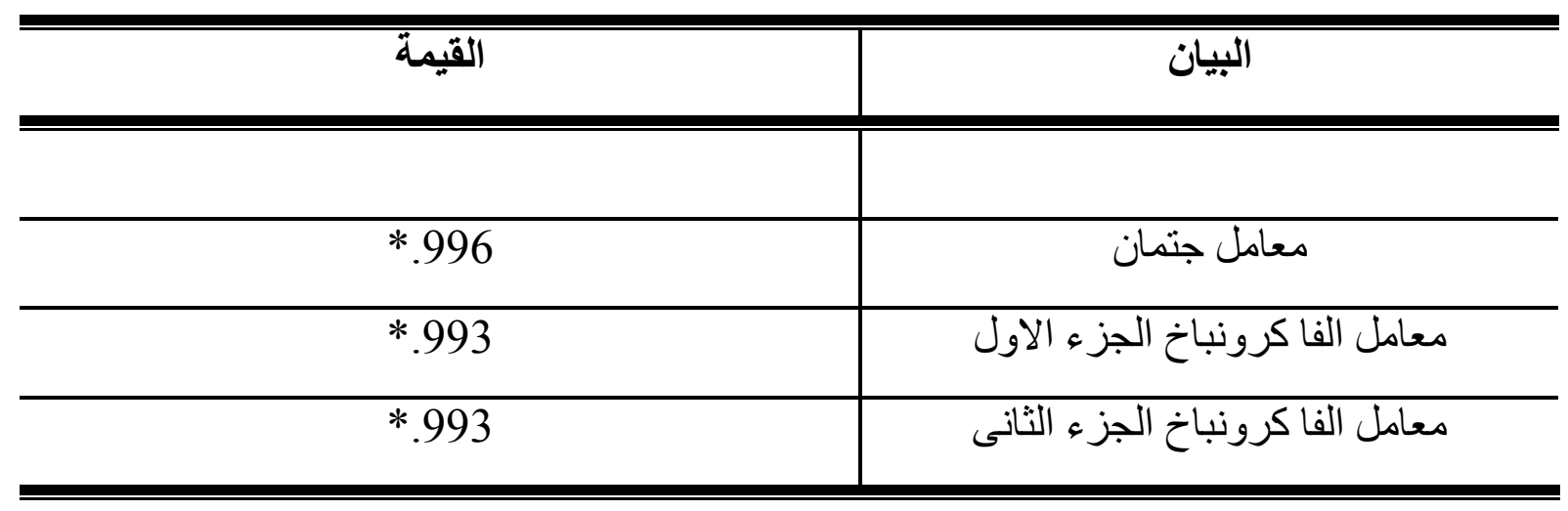

مجلة بحوث التربية الثاملة _ كلية التربية الرياضية للبنات ـ جامعة الزقازيق ـ المجلد الأول ـ للنصف الثاني للأبحاث العلمية _ V ـ ب م 


\section{و- الصورة النهائية للمقياس: مرفق ( · ( )}

بعد حساب معامل صدق وثبات مقياس "مهار ات العناية بالذات للأطفال التوحديين" أصبح المقياس

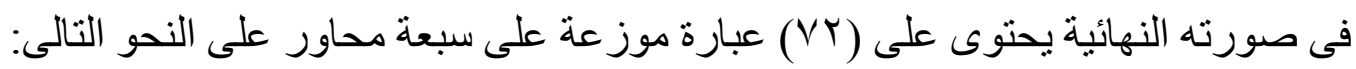

المحور الأول: التعامل مع الطعام

مقدرة الأطفال التوحديين علي تتاول الطعام، وذللك عن طريق استخدام أدوات الطعام المختلفة علي

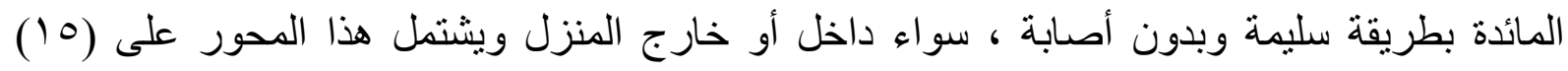

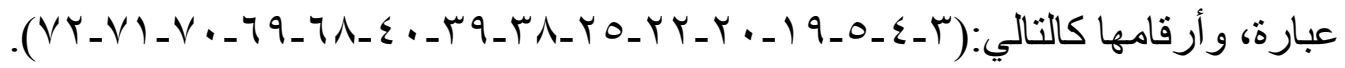
المحور الثانى: التعامل مع الثراب

مقدرة الاطفال التوحديين علي تناول الثراب وذللك عن طريق استخدام أدوات الثراب المختلفة علي

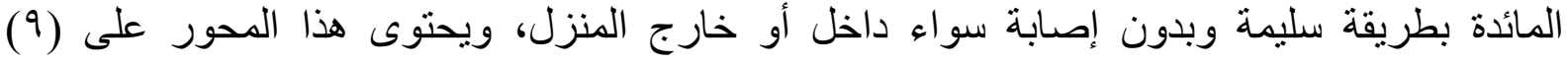

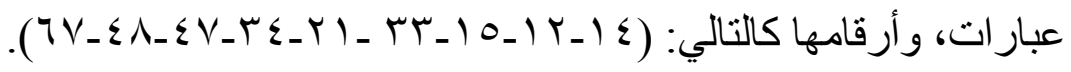

المحور الثالث: التعامل مع الملابس

مقدرة الأطفال التوحديين علي ارتداء ملابسهم بصورة صحيحة من خلال إرتداء القميص وربط التطاء

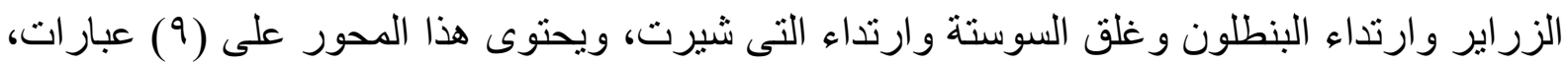

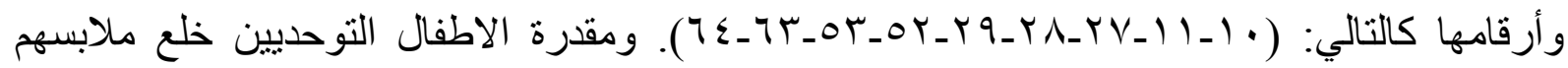

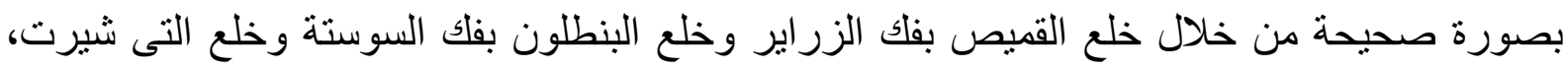

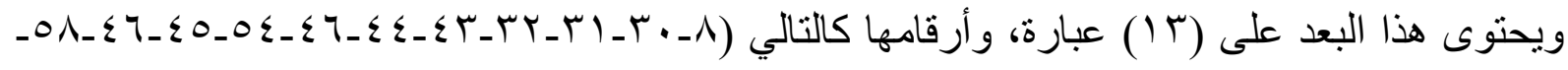

. (7V-77_ 70

المحور الرابع: قضاء الحاجة

إستطاعة الأطفال التوحديين القيام بعملية الإخر اج بصورة صحيحة، وذلك من خلال التصريح عنها فى الوقت المناسب، وكيفية خلع ملابسهم قبلها بوقت كافي، الجلوس على المقعد بهدوء و النظافة بعدها،

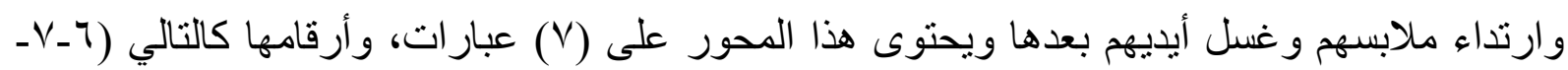

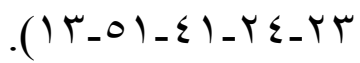

المحور الخامس: النظافة الشخصية

إستطاعة الأطفال التوحديين القيام بالنظافة الثخصية بصورة جيدة من خلال غسل الأيدي بالماء

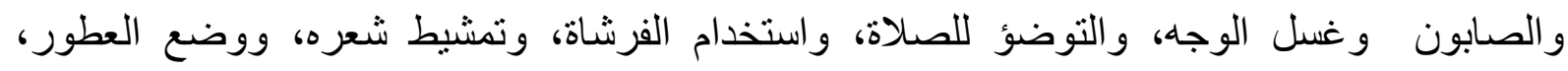

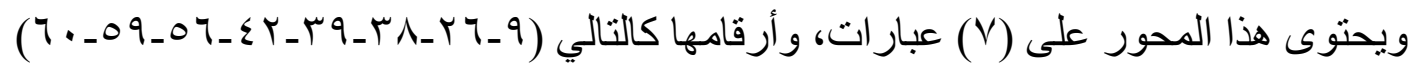

مجلة بحوث التربية الثاملة ـ كلية التربية الرياضية للبنات - جامعة الزقازيق ـ المجلد الأول ـ للنصف الثاني للأبحاث العلمية _ V ـ rم 
المحور السادس: الإحساس بالامان

إستطاعة الطفل تجنب الأشياء التى قد تؤذيه ويحتوى هذا المحور على ( 11 ( ) عبارة، وأرقامها

$$
\text { كالتالي (1) }
$$

ز- تصحيح المقياس : لتصحيح المقياس قامت الباحثة بوضع ميزان تقدير ثلاثي، وقد تم تصحيح

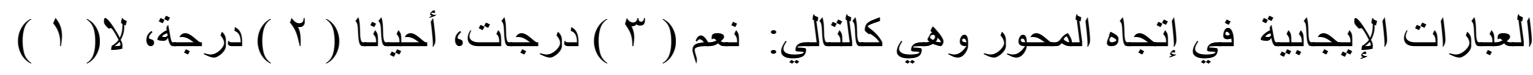
درجة واحدة، أما العبار ات السلبية في إتجاه البعد فكانت درجاتها كالتالي: نعم ( () درجة واهية واحدة ،

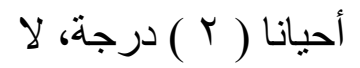

( ) ( درجات، و الدرجة التى يتم الحصول عليها تعبر عن مدى امتلاك الطفل لمهار ات العناية بالذات حيث تعبر الدرجة المنخفضة على عدم امتلاك لمهارة العناية بالذات، والدارجة المرنية المرتفعة على إتقان

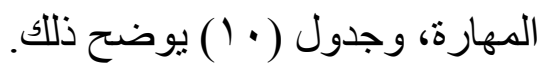

$$
\text { جلول (· (1) }
$$

الحد الأقصى والحد الأدنى لارجات مقياس مهارات

\begin{tabular}{|c|c|c|c|c|c|}
\hline \multirow{2}{*}{ للألأدجى الأدة } & \multirow{2}{*}{ اللأقصى الحد } & \multicolumn{2}{|c|}{ اتجاه العبارة } & \multirow{2}{*}{ العبار ات } & \multirow{2}{*}{ المحاور } \\
\hline & & سلبي & إيجابي & & \\
\hline 10 & $\varepsilon 0$ & $\Gamma$ & IT & 10 & تناول الطعام \\
\hline 9 & TV & $Y$ & V & 9 & تناول الثر اب \\
\hline 9 & TV & . & 9 & 9 & ارتداء الملابس \\
\hline$\pi$ & rq & $V$ & 7 & $\pi$ & خلع الملابس \\
\hline V & YI & 1 & 7 & $\mathrm{~V}$ & عملية الإخر اج \\
\hline$\Lambda$ & T乏 & $\xi$ & $\varepsilon$ & $\Lambda$ & النظافة الشخصية \\
\hline 11 & r & $\Lambda$ & $\mu$ & 11 & الاحساس بالأمان \\
\hline VY & $Y / T$ & ro & $\varepsilon V$ & $V Y$ & المجموع \\
\hline
\end{tabular}

العناية بالذات لاى الأطفال التوحديين

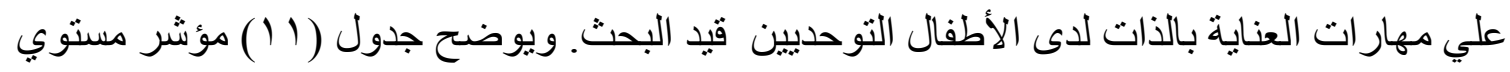
مهار ات العناية بالذات لدي الأطفال التوحديين عينة البحث. 
ك ـ مؤشر مستوي العناية بالأت:

جدول (1)

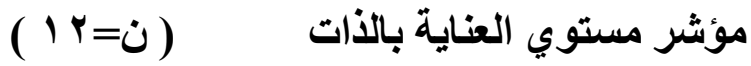

\begin{tabular}{|c|c|c|}
\hline الحد الأعلي للارجة & الحد الأدني للارجة & مؤشر مستوي العناية بالذات \\
\hline أقل من • r T & $V Y$ & منخفض \\
\hline أقل من ^1 1 & Ir. & متوسط \\
\hline Y17 & 171 & مرتفع \\
\hline
\end{tabular}

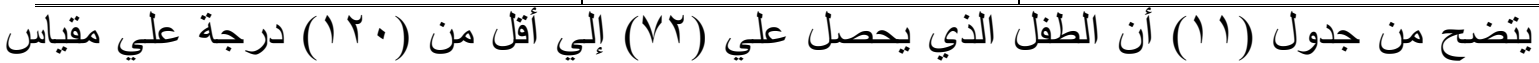
مهار ات العناية بالذات لدى الأطفال التوحديين قيد البحث مستوي مهار ات العناية بالذات لديه (منخفض)،

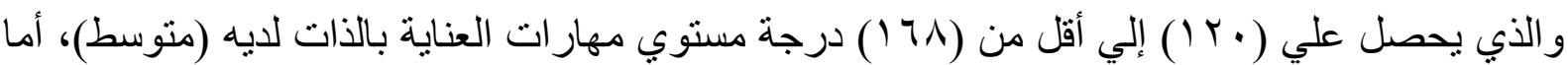

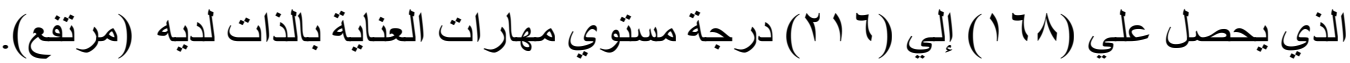

8- البرنامج المقترح : (برنامج مقترح بالألعاب لتنمية مهارات العناية بالذات لاى الأطفال التوحديين) قامت الباحثة بتطبيق البرنامج المقترح بالالعاب لتنمية مهار ات العناية بالذات لدى الأطفال التوحديين

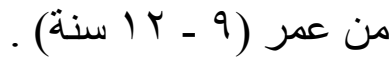
هدف البرنامج : يهدف البرنامج تقديم بد العون للأطفال التوحديين وذللك من خلال إحتو ائه علي العديد من الألعاب التي

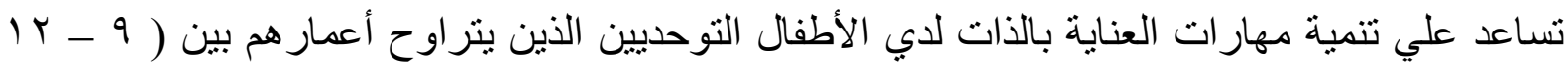
1 ـ إعطاء فرصة للأطفال التوحديين للتقة بالنفس و الاعتماد علي الذات. r-زيادة وتحسن مهار ات العناية بالذات لدي الأطفال التوحديين. محتوى البرنامج: قامت الباحثة باختيار محتوى البرنامج الحالى من خلال الاعتبار ات التالية: اـ الإطلاع على الأطرُ النظرية والدراسات السابقة التى تناولت البرامج التدريبية الخاصة بهؤلاء الأطفال، و أيضا الدر اسات التى تتناولت مهار ات العناية بالذات بشكل نظرى. rـ ملاحظة الباحثة المباثرة لمجموعة الأطفال التوحديين من خلال الزيارات الميدانية للمدرسة و المؤسسة.

rـ در اسة خصائص الأطفال التوحديين لمعرفة الاحتياجات الحقيقية لهم.

مجلة بحوث التربية الثاملة _ كلية التربية الرياضية للبنات ـ جامعة الزقازيق ـ المجلد الأول ـ للنصف الثاني للأبحاث العلمية _ V ـ ب م 
عـ إجراء عدة مقابلات مع أمهات الاطفال التوحديين و المعلمات و المشرفات و الأخصائية النفسية وذللك لمعرفة بعض البيانات و المعلومات الخاصة بهؤلاء الأطفال التوحديين والتى قد تفيد فى تتفيذ البرنامج.

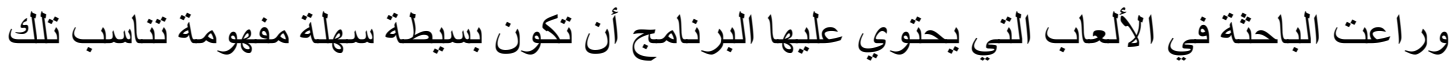
الفئة و المرحلة العمرية إلي جانب كونها ألعاب تزيد وتحسن مهار ات العناية بالذات للاطفال التوحديين و علاج بعض القصور للديهم في هذه المهار ات الأساسية لطبيعة الحياة.

تقويم البرنامج:

\section{لتقويم البرنامج إتبعت الباحثة عدة خطو ات كالآتي:}

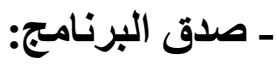

إستخدمت الباحثة صدق الخبراء حيث تم عرض البرنامج عليهم ويتضمن جميع الألعاب المختارة، فبعد إعداد البرنامج نم عرضده على عدد من خبر اء وأساتذة في علم النفس الرياضي، و الفئات الخاصة السابق ذكر هم لإبداء رأيهم فى البرنامج إعز

ـ التجربة الاستطلاعية للبرنامج:

قامت الباحثة قبل تطبيق البرنامج التدريبى بحو الى شهر بتطبيق عدد من وحدات البرنامج علي عينة البحث الاستطلاعية للتحقق من ملاعمة الإجر اءات للطفل التوحدى للتاكد من صلاحية البرنامج ووحداتها.

ـ تطبيق البرنامج:

طُُق البرنامج على المجموعة التجريبية وقوامها ( I T ) طفل توحدي يتر اوح أعمار هم بين ( 9 (

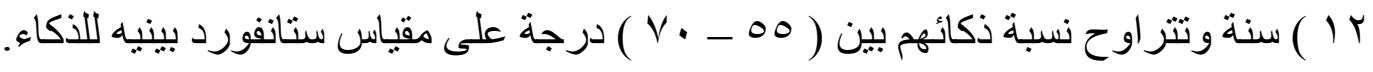

تم تطبيق البرنامج بمدارس التربية الفكرية بالعباسية، وتم التطبيق داخل كل من ( الحجرة الدر اسية ـ

$$
\text { المطعم - الحديقة ). }
$$

وتم تتفيذ البرنامج الحالى فى ( ع ) شهور بواقع ( 17 ) ) وحدة تدريبية موزعة على وحدة تدريبية

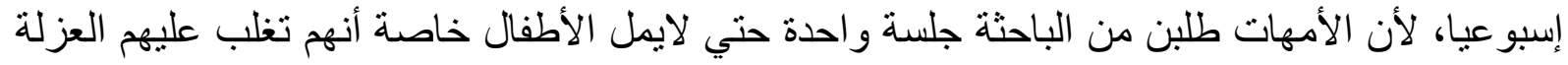

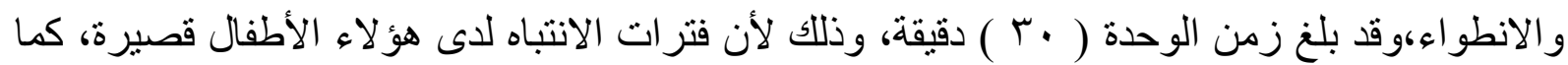

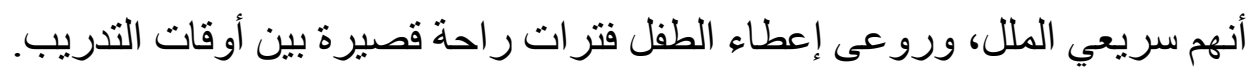
خامساً: إجراعات البحث:

قبل التطبيق: تم الحصول على الموافقات اللازمة لتطبيق إجراءات الدر اسة الحالية. ـ تم عمل مقابلات خفض التوتر و الخوف من الباحثة و إكتساب المحبة والثقة من قبل الأمهات والأطفال في الباحثة.

مجلة بحوث التربية الثاملة - كلية التربية الرياضية للبنات - جامعة الزقازيق ـ المجلد الأول ـ للنصف الثاني للأبحاث العلمية _ Y ب Y م 


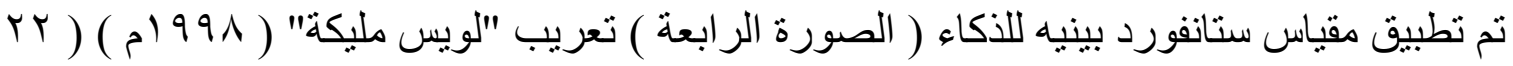

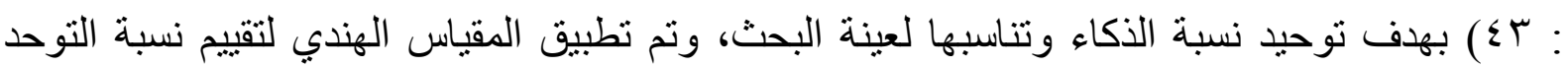

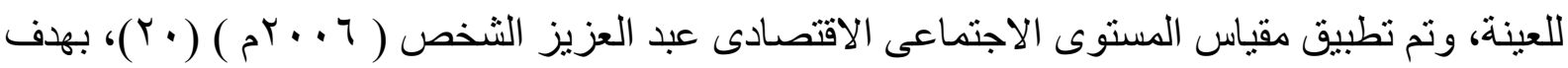
التحقق من تجانس أفراد المجموعة التجريبية، وقد قامت الإخصائية النفسية بتطبيق الثناثة مقاييس لخبرتها في هذا المجال.

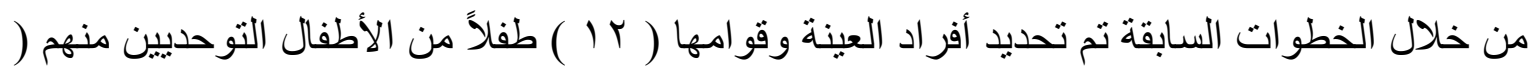

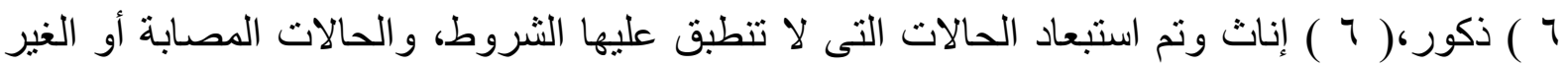
منتظمة في التدريب، وتم تطبيق مقياس مهار ات العناية بالذات على عينة الدر اسة المختارة قبلياً بتاريخ

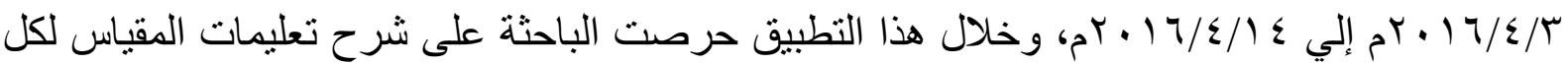

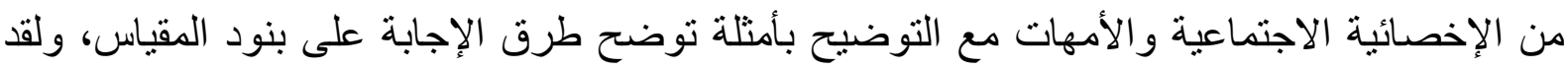
قامت الباحثة بتفريغ ورصد نتائج التطبيق القبلى إستعدادا للمعالجات الإحصائية.

تطبيق البرنامج :

قامت الباحثة قبل التنفيذ بإعداد الأدوات والمعززات ومكان تنفيذ البرنامج وتحديد الوقت المناسب لاستجابة الأطفال، حيث تم اختبار(الملعب ـ الحديقة) لتطبيق البرنامج على المجموعة التبل التجريبية الواحدة

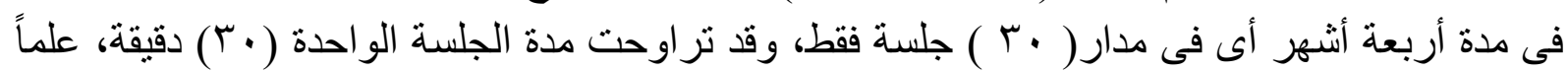

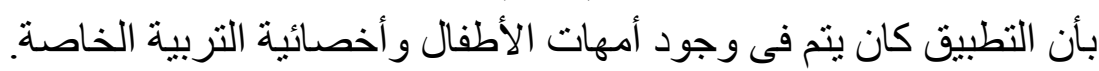
كما راعت الباحثة عند تطبيق البرنامج الوقت المناسب لاستجابة الاطفال بحيث لايكون في فترة

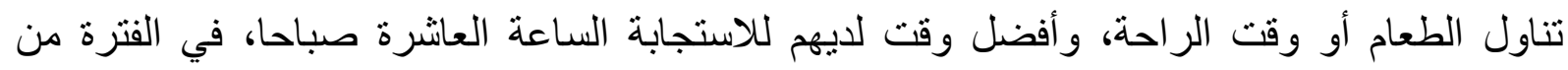

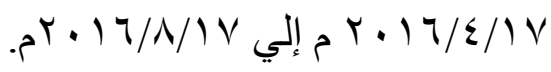
ـ أهتمت الباحثة بتكوين علاقات صداقة بينها وبين الأطفال والأمهات لعمل جو من الألفة والود و الحب بينهم ـ قامت الباحثة بتطبيق الألعاب ولاحظت الإقبال من قبل الأطفال مع الاستحسان من قبل الأمهات و الامتنان و التشجيع و التحفيز للباحثة. - إهتم الجميع بالباحثة وقدموا لها الثكر علي المجهود الذي أدي لتحسن أطفالهم واستجابتهم للبرنامج وتعلقهم بالباحثة. التطبيق البعدى لأدوات البحث:

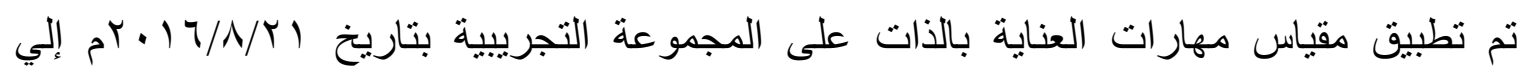
.5 $r+17 / 9 / \varepsilon$

مجلة بحوث التربية الثاملة ـ كلية التربية الرياضية للبنات - جامعة الزقازيق ـ المجلد الأول ـ للنصف الثاني للابحاث العلمية _ V + Yم 
$-9 \cdot-$

دور الألعاب في تنمية العناية بالذات لذوي الاحتياجات الخاصة

سادساً: الأسساليب الإحصائية:

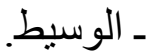

ـ المتوسط الحسابي.

ـ - م الانحر اف المعياري.

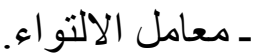

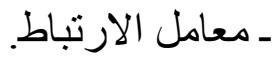

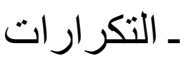

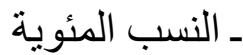

-

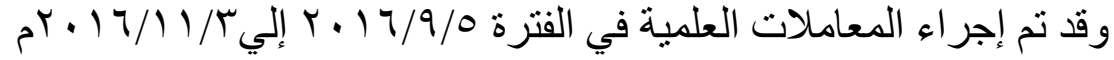

ـ - عرض ومناقثتها النتائج ـ ـ عرض التتائج للقياس القبلي: 
$-91-$

دور الألعاب في تنمية العناية بالذات لذوي الاحتياجات الخاصة

\section{جدول(r) ( )}

التكرارات والنسب المئوية والأهمية النسبية وكاب للقياسات القبلية لاي الأطفال التوحديين فى عبارات ( 1 Y $r=0$

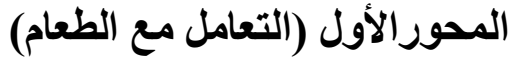

\begin{tabular}{|c|c|c|c|c|c|c|c|c|c|c|}
\hline \multirow{2}{*}{ كاץ } & \multirow{2}{*}{ الترتيب } & \multirow{2}{*}{$\%$} & \multicolumn{2}{|l|}{$y$} & \multicolumn{2}{|l|}{ احيانا } & \multicolumn{2}{|l|}{ نعم } & \multirow{2}{*}{ العبار ات } & \multirow{2}{*}{ r } \\
\hline & & & $\%$ & 5) & $\%$ & 5 & $\%$ & ك5 & & \\
\hline$r, 0$. & 0 & $\% 79, \leq \leq$ & $\% 17,7 V$ & r & \%०ᄉ,r & V & $\%$ ro, . & $r$ & ليتذوق أنو اع الطعام & $r$ \\
\hline $1,0$. & $\wedge$ & \%०ג, & $\% \leqslant 1,7 V$ & 0 & $\% \leqslant 1,7 V$ & 0 & $\% 17,7 \vee$ & $r$ & من ريعرف نو عية الأكل & $\varepsilon$ \\
\hline$\varepsilon, 0$. & r & \% \% \% & \% \%, & 1 & سז, & $\varepsilon$ & \%०ᄉ,r & V & من الطعام (إيجابية) & 0 \\
\hline$r, 0$. & V & $\%$ & $\%$ ro, . & $r$ & \%०ג,r & V & $\%) 7,7 \vee$ & $r$ & بستطيع مسك الطعام (إيجابي) & 19 \\
\hline$\varepsilon, 0$. & 1. & $\% 0 \cdot, \cdots$ & \%०ᄉ,r & V & سr, & $\varepsilon$ & $\%$ & 1 & الصئب من اللين & YI \\
\hline r,o. & 0 & $\% 79, \leq \varepsilon$ & $\% \leq 1,7 \mathrm{~V}$ & 0 & $\%$ \%,r & 1 & $\%$ & 7 & بفضل أن تطعمه الأم & rr \\
\hline$* 1 \leqslant, \ldots$ & Kr & $\% \leftrightarrow \wedge, \wedge q$ & \% \%, \% & 1. & $\% 17,7 \vee$ & r & $\%$ & & مساعدة (الملعقة بدون مسك & Tr \\
\hline r,o. & 9 & $\% \circ r, \vee \wedge$ & \%०ג, \% & V & $\%$ ro, . & $r$ & $\% 17,7 \vee$ & r & يبلع الطعام بسهولة & TV \\
\hline$* 1 \Gamma, 0$. & 1 & $\% 91,7 \vee$ & \% & 1 & \%^,r & 1 & \% \% & 1. & يكره إستخدام أدو ات & ५ᄉ \\
\hline$* 1 \pi, 0$. & 11 & $\% \leqslant 1,7 \vee$ & \% \% \% & 1. & $\%$ \%, & 1 & $\%$ & 1 & 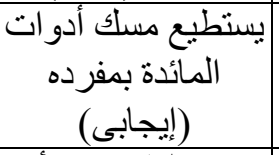 & $r q$ \\
\hline r,o. & r & $\% \wedge \cdot, 07$ & $\% 17,7 \mathrm{~V}$ & $r$ & $\%$ ro, . & $r$ & \%०^, & V & "يحب الطعام في أي & $\varepsilon$. \\
\hline $1,0$. & 7 & $\% 77,7 \vee$ & $\% \leqslant 1,7 V$ & 0 & $\% 17,7 \vee$ & $r$ & $\% \leqslant 1,7 V$ & 0 & الباخنة الكثر من الأكلات & $\leqslant V$ \\
\hline$\varepsilon, 0$. & r & \%^r,r & \% & 1 & זr, & $\varepsilon$ & \%०^, & $v$ & الطنتمتع بأكل الفاكهة & 71 \\
\hline$\cdot, 0$. & 0 & $\% 79, \leqslant \leq$ & \% & $\varepsilon$ & $\%$ ro, . & $r$ & $\% \leqslant 1,7 V$ & 0 & السندونش (إيجابي) & 79 \\
\hline $1,0$. & $\varepsilon$ & $\% \vee 0, \ldots$ & $\%$ ro, . & $r$ & $\%$ ro, . & $r$ & $\% 0 \cdot, \cdots$ & 7 & يأكل أبي طعام يقدم & $V Y$ \\
\hline
\end{tabular}

مجلة بحوث التربية الثاملة ـ كلية التربية الرياضية للبنات - جامعة الزقازيق ـ المجلد الأول ـ للنصف الثاني للأبحاث العلمية _ V ـ rم 
يتضح من جدول(Y I ) أنه لا توجد فروق ذات دلالة معنوية بين استجابات الأطفال

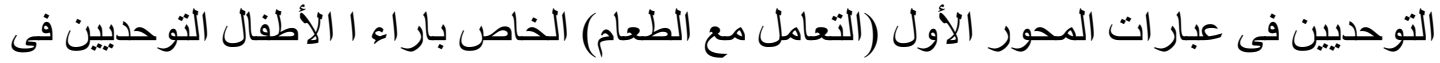

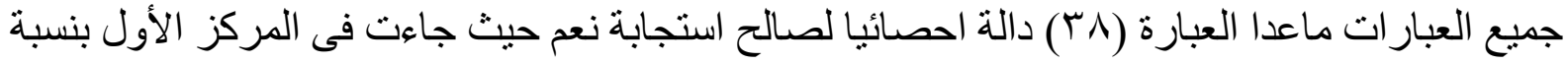

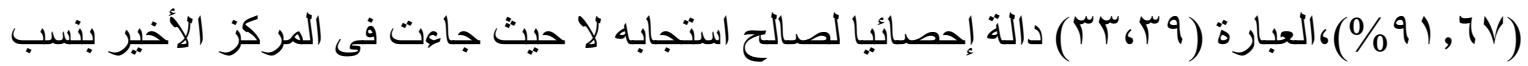

$$
\text { تراوحت مابين (\%) ( }
$$

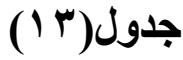

التكرارات والنسب المئوية والاهمية النسبية وكاب للقياسات القبلية لدي الأطفال التوحديين

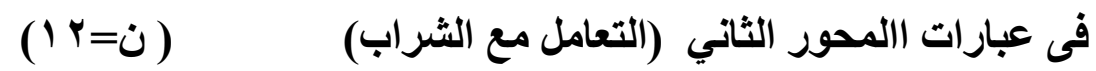

\begin{tabular}{|c|c|c|c|c|c|c|c|c|c|c|}
\hline \multirow{2}{*}{ كاץ } & \multirow{2}{*}{ الترنيب } & \multirow{2}{*}{$\%$} & \multicolumn{2}{|l|}{$\bar{\gamma}$} & \multicolumn{2}{|l|}{ احيانا } & \multicolumn{2}{|l|}{ نعم } & \multirow{2}{*}{ العبار ات } & \multirow{2}{*}{ م } \\
\hline & & & $\%$ & ك5 & $\%$ & ك5 & $\%$ & 5) & & \\
\hline$r, \ldots$ & r & $\%) \vee, \leqslant 7$ & $\% 0^{0}, \ldots$ & 7 & $\% 17,7 \vee$ & $r$ & אז, & $\varepsilon$ & | ليحب العصائر (إيجابي) & $1 \leqslant$ \\
\hline$r, \ldots$ & r & $\% \backslash \vee, \leqslant 7$ & $\% 0^{0}, \ldots$ & 7 & $\% 17,7 \vee$ & $r$ & سז, & $\varepsilon$ & الباردة (سلبى) السئل & 10 \\
\hline $\begin{array}{c}1 \cdot, 0 . \\
*\end{array}$ & $\varepsilon$ & $\% 11,9$. & $\% \vee 0, \ldots$ & 9 & $\%$ ro, . & $r$ & $\% \cdot, \cdots$ & & "الزب باجة إلىى من & Tะ \\
\hline$\cdot, 0$ & 1 & $\% \backslash \wedge, Y_{0}$ & $\% \leqslant 1,7 V$ & 0 & $\%$ ro, . & $r$ & חז, \% & $\varepsilon$ & يفرق بين المياه & $\leqslant \wedge$ \\
\hline 1,0 & $r$ & $\% 17,7 V$ & $\% \leq 1,7 V$ & 0 & $\% \leqslant 1,7 \vee$ & 0 & $\% 17,7 \vee$ & r & بقوم بفتح الزجاجة & 07 \\
\hline $\begin{array}{c}11,0 . \\
*\end{array}$ & 0 & \% & $\% 91,7 \mathrm{~V}$ & 11 & \% & 1 & $\% \cdot, \cdots$ & & لقابكر علي ملأ & $T V$ \\
\hline
\end{tabular}

يتضح من جدول (1 (1) أنه لاتوجد فروق ذات دلالة معنوية بين استجابات الأطفال التوحديين فى (لئ

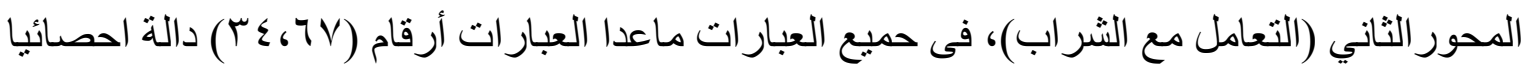

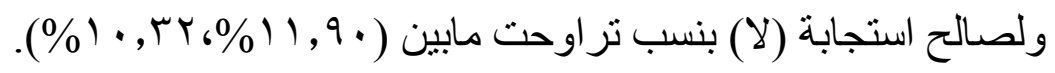

مجلة بحوث التربية الثاملة ـ كلية التربية الرياضية للبنات - جامعة الزقازيق ـ المجلد الأول ـ للنصف الثاني للأبحاث العلمية _ V ـ rم 
$-94-$

\section{جدول( ) (1)}

التكرارات والنسب المئوية والاهمية النسبية وكاץ للقياسات القبلية لاي الأطفال

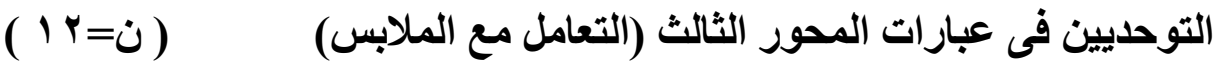

\begin{tabular}{|c|c|c|c|c|c|c|c|c|c|c|}
\hline \multirow{2}{*}{ كاr } & \multirow{2}{*}{ 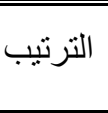 } & \multirow{2}{*}{$\%$} & \multicolumn{2}{|l|}{$\bar{y}$} & \multicolumn{2}{|l|}{ احيانا } & \multicolumn{2}{|l|}{ نعم } & \multirow{2}{*}{ 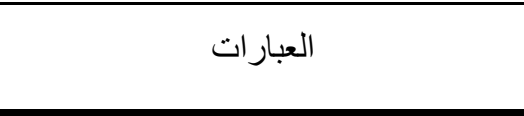 } & \multirow{2}{*}{ r } \\
\hline & & & $\%$ & 5 & $\%$ & S & $\%$ & (5) & & \\
\hline r, . & V & $\% V Y, Y Y$ & ( ) & $\varepsilon$ & $\% 17,7 \mathrm{~V}$ & r & $\% 0 \cdot, \cdots$ & 7 & يعرف الفرق بين البنطال و الثورت & $1 \cdot$ \\
\hline$* 7, \cdots$ & 11 & $\% 0 \cdot, \ldots$ & $\%$ \%า, フ & $\wedge$ & $\% 17,7 \mathrm{~V}$ & $r$ & $\%) 7,7 \mathrm{~V}$ & $r$ & يسنطيع معرفة يمين ويسار الحذاء (إيجابي) & TV \\
\hline r, . & 0 & $\% \vee \vee, \vee \wedge$ & $\% 17,7 \mathrm{~V}$ & T & \% & $\varepsilon$ & $\% 0 \cdot, \cdots$ & 7 & يققل سوستة البنطال (إيجابي) & rA \\
\hline$\varepsilon, 0$ & 9 & \%०ג,r & \%०ג,T & $\mathrm{V}$ & \% & 1 & \% & $\varepsilon$ & يلبس فردني الحذاء بنظام (إيجابي) & rq \\
\hline$* \backslash \wedge, 0$ & 1T & $\% \sqcap \wedge, \wedge q$ & $\% 91,7 \vee$ & 11 & $\% \cdot, \cdots$ & & \% & 1 & يعرف فردتي الحذاء (ارتداء الملابس) & $\varepsilon r$ \\
\hline $1 \leq, \ldots *$ & 14 & $\%$ \% , ^q & $\%$ & 1 . & $\% 17,7 V$ & $r$ & $\% \cdot, \cdots$ & & يفرق بين فردتي الحذاء (إيجابي) & or \\
\hline$* \uparrow, 0$. & ir & $\% \leqslant V, r r$ & $\% 77,7 \vee$ & $\wedge$ & $\%$ ro, . & r & \% & 1 & يحب ارتداءالملابس بدون زر اير او سوستة & or \\
\hline$\varepsilon, 0$ & 11 & $\% 0 \cdot, \cdots$ & \%०ג, & V & \% & $\varepsilon$ & \% & 1 & يحب لبس الجاكت (إيجابي) & $7 r$ \\
\hline$r, \ldots$ & $1 \cdot$ & $\% 00,07$ & $\% 0^{0 \cdot, \cdots}$ & 7 & \% & $\varepsilon$ & $\% 17,7 V$ & $r$ & يفضل ارتداء القبعة (إيجابي) & $7 \pi$ \\
\hline$\varepsilon, 0$ & 7 & $\% \vee 0, \ldots$ & \% & $\varepsilon$ & \% \%,ru & 1 & \%०ג,ז & 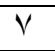 & يخلع حذائه بمفرده دون مساعدة (إيجابي) & 11 \\
\hline$* r \varepsilon, \cdots$ & 10 & \% & $\%$ & it & $\% \cdot, \cdots$ & & $\% \cdot, \cdots$ & & يصعب عليه خلع الفانلة (سلبى) & IT \\
\hline$\cdot, 0$ & $\Lambda$ & $\% 71,11$ & $\% \approx 1,7 \mathrm{~V}$ & 0 & \% & $\varepsilon$ & $\%$ ro,.. & $r$ & يقطع الفانلة عند خلعها (سلبي) & 14 \\
\hline r,o. & 1. & $\% 00,07$ & \%०ג,T & $\mathrm{V}$ & $\% 17,7 \mathrm{~V}$ & $r$ & $\%$ Yo, .. & $r$ & يمزق الملابس عند خلعها (سلبى) & r. \\
\hline$* 7,0$ & $r$ & $\% \wedge \neg, 11$ & \% & 1 & $\%$ Yo, . & $r$ & $\%$ & $\wedge$ & يفك زراير القميص (إيجابي) & T \\
\hline$\varepsilon, 0$ & $\varepsilon$ & \% \% & \% \% & 1 & \% & $\varepsilon$ & \%०ג,r & $\mathrm{V}$ & يقدر علي خلع الملابس الداخلية (إيجابي) & rr \\
\hline$* \backslash \wedge, 0$ & $1 \varepsilon$ & $\%$ & $\% 91,7 \mathrm{~V}$ & 11 & \% & 1 & $\% \cdot, \cdots$ & & يقدر على خلع التيشيرت (إيجابي) & $\varepsilon r$ \\
\hline$* 9,0$. & $r$ & $\% \wedge 7,11$ & $\% 17,7 \mathrm{~V}$ & $r$ & \%^,r & 1 & $\% \vee 0, \ldots$ & 9 & يقطع الملابس عند خلعها (سلبي) & $\varepsilon \varepsilon$ \\
\hline$* 7,0$ & Ir & $\% \varepsilon V, Y Y$ & $\%$ & $\Lambda$ & $\%$ Yo, .. & $r$ & $\%$ & 1 & يصعب عليه خلع الملابس(سلبي) & $\leqslant 0$ \\
\hline$* 7,0$ & ir & $\% \leqslant \vee, Y Y$ & $\% 77,7 \vee$ & $\wedge$ & $\%$ YO, . & $r$ & $\%$ & 1 & يصعب عليه خلّع الحذاء(سلبي) & $\leqslant 7$ \\
\hline 1,0 & 7 & $\% \vee \vee, \ldots$ & $\% 17,7 \vee$ & r & $\%\{1,7 V$ & 0 & $\% \leqslant 1,7 V$ & 0 & يخرج ر أسه من الملابس ببساطة (خلع & os \\
\hline$* \eta, \cdots$ & 11 & $\% 0 \cdot, \cdots$ & $\%$ & $\Lambda$ & $\% 17,7 V$ & $r$ & $\% 17,7 V$ & $r$ & يخلع ملابسـ بنفسه داخل الحمام (إيجابي) & 09 \\
\hline$* 1 \cdot, 0$ & 1 & $\% 91,7 \mathrm{~V}$ & $\% \cdot, \cdots$ & & $\%$ Yo,, & $r$ & $\% \vee 0, \ldots$ & 9 & يخلع غطاء الر أس أولاً (سلبي) & $7 \varepsilon$ \\
\hline$\varepsilon, 0$ & 11 & $\% 0 \cdot, \cdots$ & $\%$ & V & \% \% & $\varepsilon$ & $\%$ & 1 & يقدر على خلع الأكمام بسهولة (إيجابي) & 70 \\
\hline$*) \leq, \cdots$ & r & $\% \wedge \wedge, \wedge q$ & $\% 17,7 \vee$ & $r$ & $\% \cdot, \cdots$ & & \% & 1. & يصعب عليه فلك أزرار أكمام الجاكت & 77 \\
\hline
\end{tabular}

يتضح من جدول(ع () أنه توجد فروق ذات دلالة معنوية بين استجابات الأطفال التوحديين

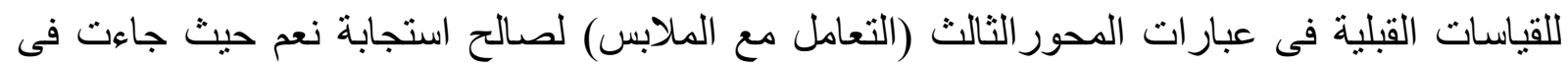

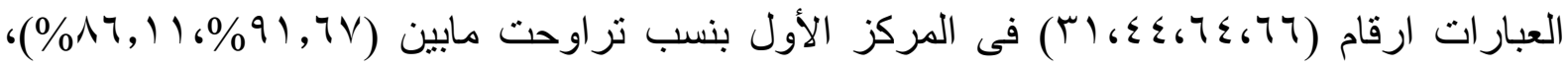

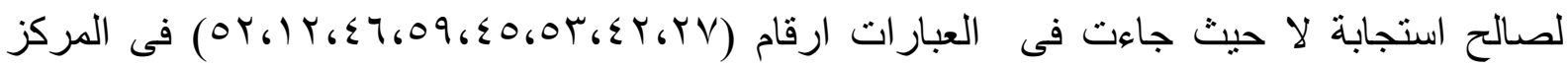

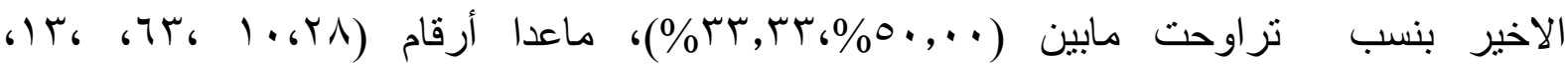

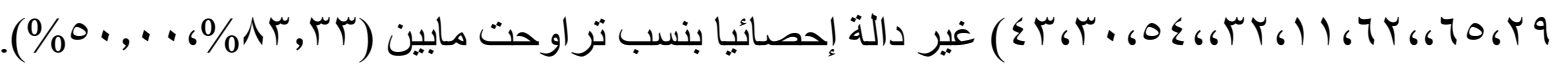


$-9 \leq-$

دور الألعاب في تنمية العناية بالذات لذوي الاحتياجات الخاصة

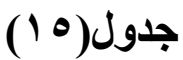

التكرارات والنسب المئوية والأهمية النسبية وكا؟ للقياسات القبلية لاي الأطفال

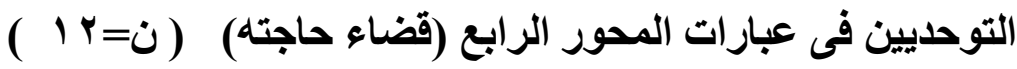

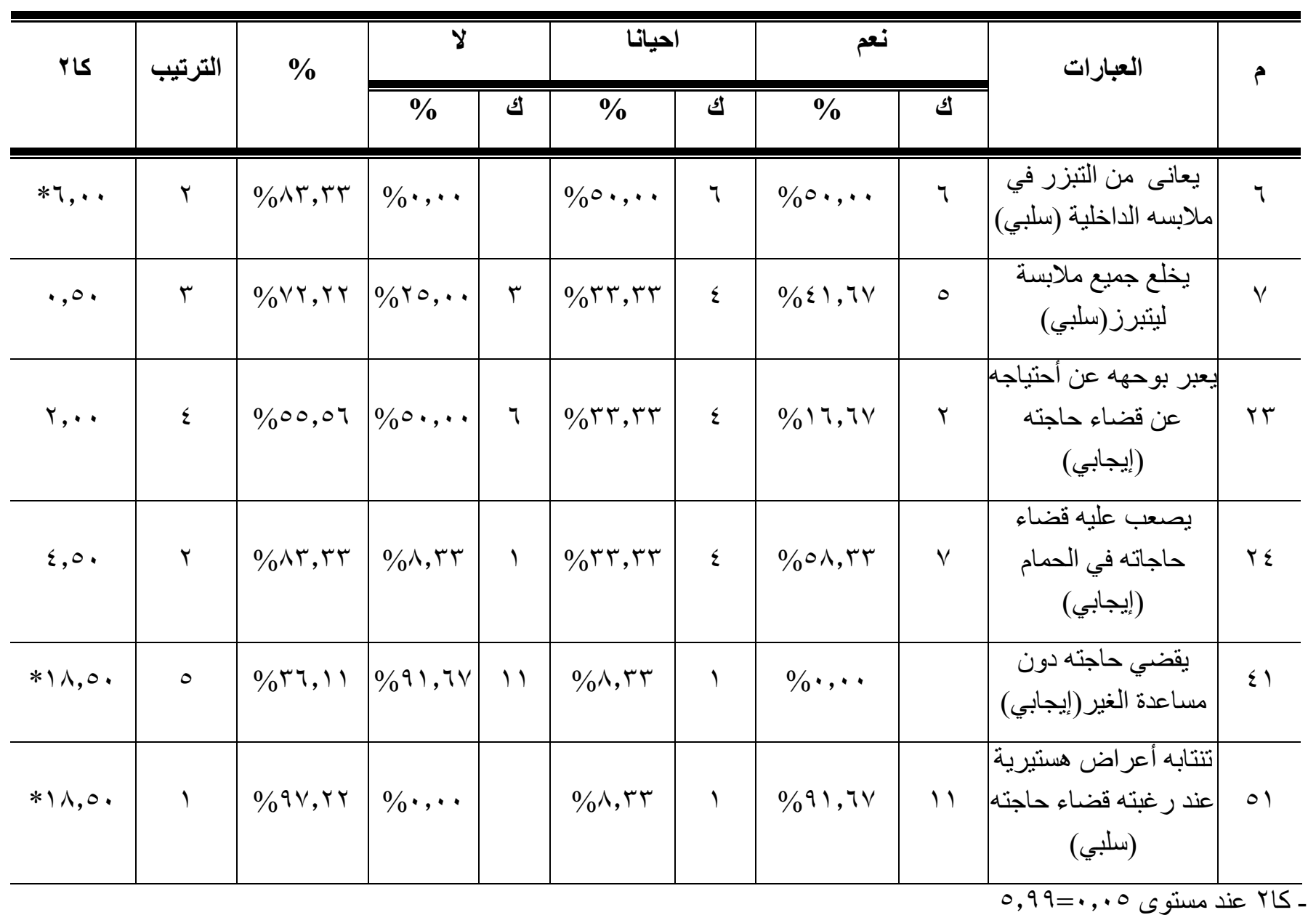

يتضح من جدول (10 ) أنه لاتوجد فروق ذات ألات دلالة معنوية لاى استجابات الأطفال التوحديين للقياسات

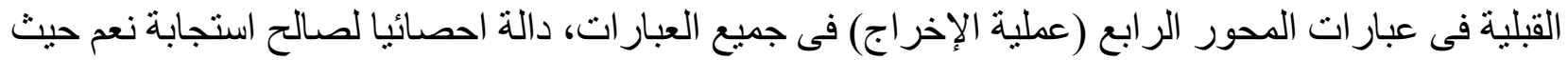

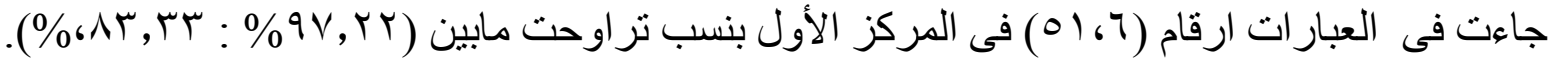

مجلة بحوث التربية الثاملة _ كلية التربية الرياضية للبنات ـ جامعة الزقازيق ـ المجلد الأول ـ للنصف الثاني للأبحاث العلمية _ V ـ ب م 
-90 -

دور الألعاب في تنمية العناية بالذات لذوي الاحتياجات الخاصة

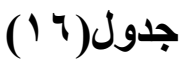

التكرارات والنسب المئوية والاهمية النسبية وكاץ للقياسات القبلية لدي الأطفال

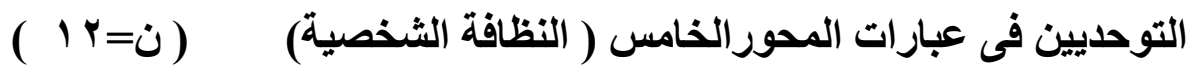

\begin{tabular}{|c|c|c|c|c|c|c|c|c|c|c|}
\hline \multirow{2}{*}{ كاץ } & \multirow{2}{*}{ الترتيب } & \multirow{2}{*}{$\%$} & \multicolumn{2}{|l|}{$y$} & \multicolumn{2}{|c|}{ احيانا } & \multicolumn{2}{|c|}{ ن نعم } & \multirow[t]{2}{*}{ العبار ات } & \multirow{2}{*}{ r } \\
\hline & & & $\%$ & ك & $\%$ & ك & $\%$ & 5 & & \\
\hline$\cdot 0$. & 0 & $\% 71,11$ & $\% \leqslant 1,7 \vee$ & 0 & سז, & $\varepsilon$ & $\%$ ro, . & $r$ & بخاف من غسل وجهابه & 9 \\
\hline$r, 0$. & $\varepsilon$ & $\%\urcorner 9, \varepsilon \leqslant$ & $\% \leqslant 1,7 V$ & 0 & $\%$ \%, r & 1 & $\% 0^{\circ},, \cdots$ & 7 & يحب غسيل يده ورجله & ro \\
\hline$* 7,0$. & 7 & $\% \circ r, \vee \wedge$ & \% \% & $\wedge$ & $\%$ & 1 & $\%$ ro, . & $r$ & بالثامبو (إيجابي) شعل & YT \\
\hline $1,0$. & $r$ & $\% \vee 0, \ldots$ & $\%$ ro, .. & $r$ & $\%$ ro,.. & $r$ & $\% 0^{\circ}, \ldots$ & 7 & 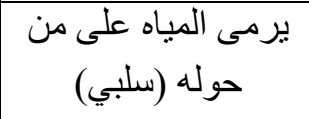 & 00 \\
\hline$* 1 \Gamma, 0$. & 1 & $\% 91,7 V$ & $\%$ & 1 & $\%$ \%, r & 1 & \% \% & 1. & الأظافربمفرده (سلبي) تخشي) & 7. \\
\hline$* \eta, \ldots$ & 7 & $\% 0^{\circ},, \cdots$ & $\%$ & $\wedge$ & $\% 17,7 \mathrm{~V}$ & $r$ & $\% 17,7 \vee$ & $r$ & العطور (إيجابي) & 71 \\
\hline$* q, 0$. & $r$ & $\% \wedge \wedge, \wedge q$ & \% & 1 & $\% 17,7 \vee$ & $r$ & $\% \vee 0, \ldots$ & 9 & بخشتى غسل شعره & $\gamma$. \\
\hline$*\rceil, 0$. & 7 & $\% \circ$ Y, VA & $\%$ & $\wedge$ & $\%$ & 1 & $\%$ ro,.. & $r$ & يحب الاستحمام بمفرده & $V_{1}$ \\
\hline
\end{tabular}

يتضح من جدول (7 (1) أنه نوجد فروق ذات ذات دلالة معنوية لدى استجابات الأطفال التوحديين

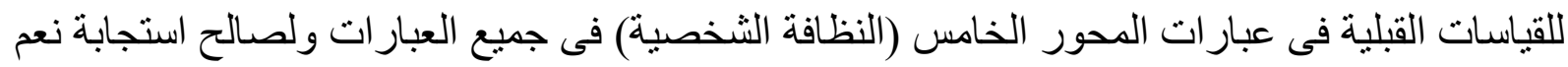

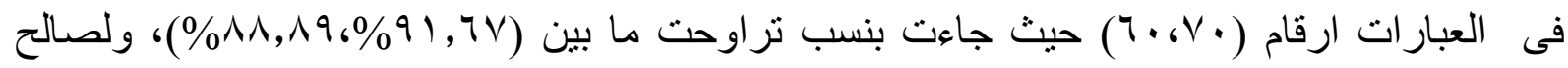

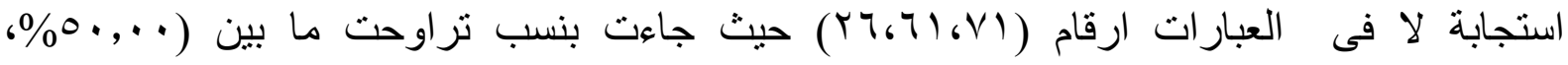

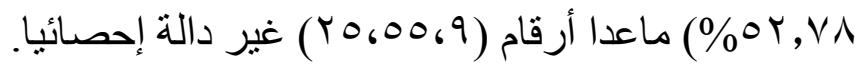

مجلة بحوث التربية الثاملة ـ كلية التربية الرياضية للبنات - جامعة الزقازيق ـ المجلد الأول ـ للنصف الثاني للأبحاث العلمية _ V ـ rم 
-97 -

دور الألعاب في تنمية العناية بالذات لذوي الاحتياجات الخاصة

جدول (iv)

التكرارات والنسب المئوية والأهمية النسبية وكاب للقياسات القبلية لاي الأطفال

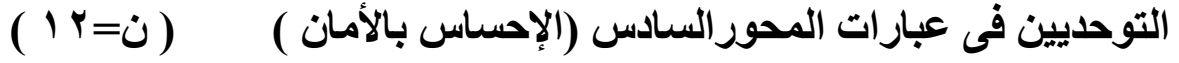

\begin{tabular}{|c|c|c|c|c|c|c|c|c|c|c|}
\hline \multirow{2}{*}{ كاץ } & \multirow{2}{*}{ الترتبب } & \multirow{2}{*}{$\%$} & \multicolumn{2}{|l|}{$\gamma$} & \multicolumn{2}{|c|}{ احيانا } & \multicolumn{2}{|c|}{ نعم } & \multirow{2}{*}{ العبار ات } & \multirow{2}{*}{ مسلسل } \\
\hline & & & $\%$ & 5 & $\%$ & 5 & $\%$ & 5 & & \\
\hline$* q, 0$. & 0 & $\%\urcorner 9, \leq \varepsilon$ & سז,^^\% & 1 & $\% \vee 0, \ldots$ & 9 & $\% 17,7 \mathrm{~V}$ & r & بضرب وجهه بالبدين & 1 \\
\hline$* \mid \wedge, 0$. & 1 & $\% q V, r r$ & $\% \cdot, \cdots$ & & \% & 1 & $\% 91,7 \mathrm{~V}$ & 11 & لزيخاف من الذهاب & r \\
\hline r,o. & $\Lambda$ & $\% 00,07$ & سז,0ג\% & V & $\% 17,7 \vee$ & $r$ & $\%$ Yo, . & r & |بستطيع فتح باب الغرفة & $\wedge$ \\
\hline$\cdot, \cdots$ & 7 & $\%$ \% , ฯ & سז, & $\varepsilon$ & سץ, سז\% & $\varepsilon$ & سז, & $\varepsilon$ & | يلعب بالأشياء الخطيرة & 17 \\
\hline$r, \ldots$ & V & $\% 71,11$ & $\% 0^{\circ}, \ldots$ & 7 & $\% 17,7 \vee$ & $r$ & سז, & $\varepsilon$ & يضع الأقلام في عينه & $1 V$ \\
\hline$* 7,0$. & $\varepsilon$ & $\% \wedge \cdot, 07$ & $\%$ ro,.. & r & \% & 1 & $\% 77,7 \vee$ & $\Lambda$ & |لأب التو دائما(إيجابي) مع الأم او) & 11 \\
\hline$\cdot, \cdots$ & 7 & $\%$ \% , ТV & سז,سז\% & $\varepsilon$ & سץ, & $\varepsilon$ & سז, & $\varepsilon$ & $\begin{array}{l}\text { بحب الخروج إلى الحدائق(إيجابي) }\end{array}$ & o \\
\hline$* \mid \leq, \cdots$ & 9 & $\% \varepsilon \varepsilon, \varepsilon \varepsilon$ & \% & 1. & $\% \cdot, \cdots$ & & $\% 17,7 \vee$ & r & الصخشى الذهاب لدى الدعار & qu \\
\hline *Ir,o. & r & $\% 91,7 V$ & \% \%, & 1 & \% & 1 & سז, \% & 1. & يقدر على اللعب مع رقائه (إيجابي) & $\leqslant 9$ \\
\hline$* \mid \wedge, 0$ & 1. & \% & $\% 91,7 \vee$ & 11 & אץ,^^\% & 1 & $\% \cdot, \cdots$ & & المنب التواجد فى (إيجابي) & 0. \\
\hline$* 1 \wedge, 0$ & 1 & $\% q V, r Y$ & $\% \cdot, \cdots$ & & \% \%,r & 1 & $\% 91,7 \mathrm{~V}$ & 11 & $\begin{array}{c}\text { بنام بجانب الأم بمفردة } \\
\text { (إيجابي) }\end{array}$ & OV \\
\hline$* 1 \leq, \ldots$ & r & $\% \wedge \wedge, \wedge q$ & $\% 17,7$ & r & $\%$ & & \% \% \% & 1. & المشي ركوب & $0 \wedge$ \\
\hline
\end{tabular}

مجلة بحوث التربية الثاملة _ كلية التربية الرياضية للبنات ـ جامعة الزقازيق ـ المجلد الأول ـ للنصف الثاني للأبحاث العلمية _ V ـ ب م 
يتضح من جدول(V V ) أ نه توجد فروق ذات دلالة معنوية لدى استجابات الأطفال التوحديين

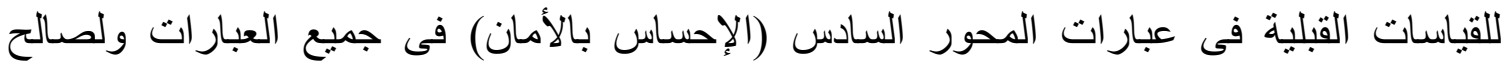

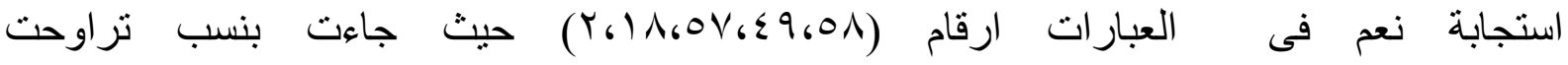

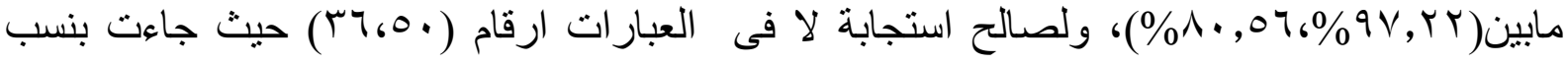

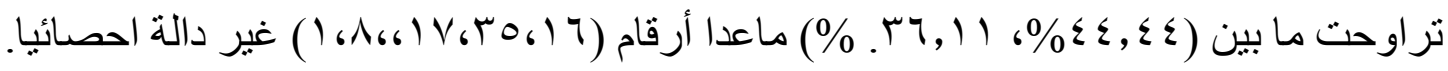

\section{جدول(1)}

التكرارات والنسب المئوية والاهمية النسبية وكاץ للقياسات البعدية لاي الأطفال

التوحديين فى عبارات المحور الأول (التعامل مع الطعام)

$(1 Y=\dot{0})$

\begin{tabular}{|c|c|c|c|c|c|c|c|c|c|c|}
\hline \multirow{2}{*}{ كاץ } & \multirow{2}{*}{ الترتيب } & \multirow{2}{*}{$\%$} & \multicolumn{2}{|l|}{ ע } & \multicolumn{2}{|l|}{ 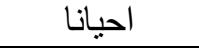 } & \multicolumn{2}{|l|}{ نعم } & \multirow{2}{*}{ العبار ات } & \multirow{2}{*}{ s } \\
\hline & & & $\%$ & 5 & $\%$ & 5 & $\%$ & 5) & & \\
\hline$* 7,0$. & $\bar{r}$ & $\% \wedge 7,11$ & \%^,r & 1 & $\%$ Yo, .. & $r$ & $\%$ & $\Lambda$ & يتذوق أنواع الطعام المختلفة (إيجابي) & $\bar{r}$ \\
\hline$* 7,0$ & $r$ & $\% \wedge \neg, 11$ & $\% \cdot, \cdots$ & $\cdot$ & $\% \leqslant 1,7 V$ & 0 & $\%$ & $\mathrm{~V}$ & يعرف نو عية الاكل من رائحته (إيجابي) & $\varepsilon$ \\
\hline$\varepsilon, 0$ & $\varepsilon$ & \% & \% & 1 & \% & $\varepsilon$ & \%०ᄉ,T & $\mathrm{V}$ & بطلب نو عية معينة من الطعام (إيجابي) & 0 \\
\hline$* 9,0$ & r & $\% \wedge \wedge, \wedge q$ & \% & 1 & $\% 17,7 \mathrm{~V}$ & $r$ & $\% \vee 0, \ldots$ & 9 & يستطيع مسلك الطعام بمفرده (إيجابي) & 19 \\
\hline$* 7,0$ & $\Lambda$ & $\% \varepsilon V, Y Y$ & $\%$ & $\wedge$ & $\%$ Yo,... & $r$ & \% & 1 & يعرف الطعام الصلب من اللين (إيجابي) & $Y_{1}$ \\
\hline$* 9,0$ & 9 & $\% \leqslant \varepsilon, \leqslant \leqslant$ & $\% \vee 0, \cdots$ & 9 & $\% 17,7 \mathrm{~V}$ & r & \% & 1 & ن تطعمه الأم بفمه (إيجابي) & Tr \\
\hline$* q, 0$. & r & $\% \wedge \wedge, \wedge q$ & \% س & 1 & $\% 17,7 \mathrm{~V}$ & r & $\% \vee 0, \cdots$ & 9 & يقدر على مسك الملعقة بدون مساعدة & 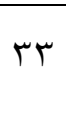 \\
\hline 1,0 & $\mathrm{~V}$ & $\%$ & $\% \leqslant 1,7 V$ & 0 & $\% 17,7 \mathrm{~V}$ & $r$ & $\% \leqslant 1,7 V$ & 0 & يبلع الطعام بسهولة (إيجابي) & rV \\
\hline$* 7,0$ & $\Lambda$ & $\% \leq V, Y Y$ & $\%$ & $\Lambda$ & $\%$ Y & $r$ & \% & 1 & يكره إستخدام أدوات المائدة (سلبي) & rᄉ \\
\hline * & 1 & $\% 91,7 \vee$ & \% & 1 & \% & 1 & \% & $1 \cdot$ & $\begin{array}{c}\text { يستطيع مسك أدو ات المائدة بمفرده } \\
\text { (إيجابي) }\end{array}$ & rq \\
\hline r,o. & 0 & $\% \wedge \cdot, 07$ & $\% 17,7 \mathrm{~V}$ & $r$ & $\%$ Y & $r$ & \%оN, & V & يحب الطعام في أي وقت (إيجابي) & $\varepsilon$. \\
\hline $1,0$. & V & $\%$ \% , ТV & $\% \leqslant 1,7 \vee$ & 0 & $\%) 7,7 \vee$ & r & $\% \leq 1,7 \vee$ & 0 & يحب الاكلات الساخنة أكثر من الباردة & $\varepsilon V$ \\
\hline$\varepsilon, 0$ & $\varepsilon$ & \% & \% & 1 & \% & $\varepsilon$ & \% \% & V & يستمتع بأكل الفاكهة الطازجة (إيجابي) & 71 \\
\hline$* 9,0$ & $\mu$ & $\% \wedge 7,11$ & $\% 17,7 \vee$ & $r$ & \% & 1 & $\% \vee 0, \cdots$ & 9 & يفضل مسك السندونش (إيجابي) & 79 \\
\hline $1,0$. & 7 & $\% \vee 0, \ldots$ & $\%$ Yo,... & $r$ & $\%$ Yo,... & $r$ & $\% 0^{0}, \cdots$ & 7 & يأكل أي طعام يقدم إلبه (إيجابي) & VY \\
\hline
\end{tabular}

كاب عند مستوى 0,99=.,

مجلة بحوث التربية الثاملة _ كلية التربية الرياضية للبنات - جامعة الزقازيق ـ المجلد الأول ـ للنصف الثاني للابحاث العلمية _ V ـ Y م 
-91 .

دور الألعاب في تنمية العناية بالذات لذوي الاحتياجات الخاصة

يتضح من جدول(1 (1) أنه توجد فروق ذات دلالة معنوية بين استجابات الأطفال التوحديين

للقياسات البعدية فى عبار ات المحور الأول (التعامل مع الطعام) الخاص بار اء ا الأطفال التوحديين

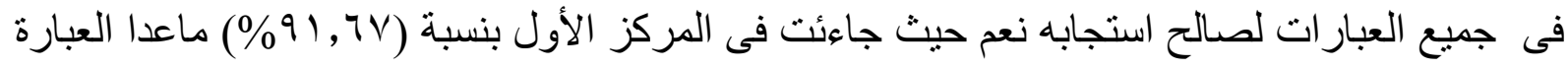

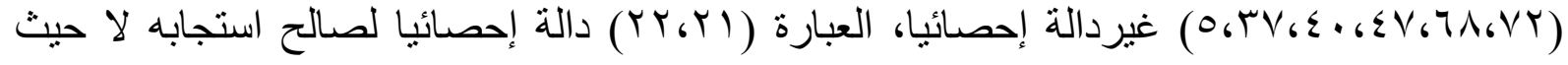

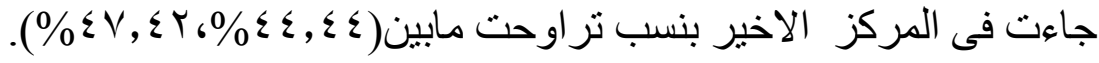

\section{جدول(9)}

التكرارات والنسب المئوية والأهمية النسبية وكاץ للقياسات البعدية لاي الأطفال

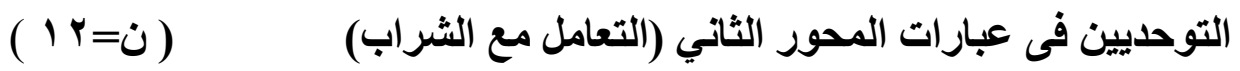

\begin{tabular}{|c|c|c|c|c|c|c|c|c|c|c|}
\hline \multirow{2}{*}{ كاץ } & \multirow{2}{*}{ الترتيب } & \multirow{2}{*}{$\%$} & \multicolumn{2}{|l|}{$\bar{\nu}$} & \multicolumn{2}{|c|}{ 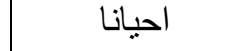 } & \multicolumn{2}{|c|}{ نعم } & \multirow{2}{*}{ 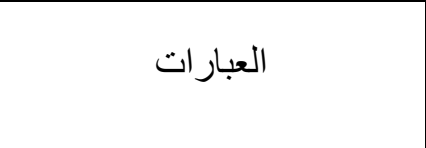 } & \multirow{2}{*}{ r } \\
\hline & & & $\%$ & ك & $\%$ & ك & $\%$ & 5 & & \\
\hline$r, \ldots$ & $\mu$ & $\% 71,11$ & $\%$ & 7 & $\%, 7,7 V$ & r & \% & $\varepsilon$ & يحب العصائر الساخنة (إيجابي) & $1 \varepsilon$ \\
\hline$r, \ldots$ & r & $\% 71,11$ & $\%$ & 7 & $\% 17,7 V$ & T & \% & $\varepsilon$ & يكره السو ائل الباردة (سلبي) & 10 \\
\hline $\begin{array}{c}1 ., 0 \\
*\end{array}$ & 1 & $\% 91,7 \mathrm{~V}$ & $\% \cdot, \cdots$ & - & $\%$ ro, . . & $r$ & $\% \vee 0, \ldots$ & 9 & يصب بنفسه من الزجاجة إلى إلكوب & $r \varepsilon$ \\
\hline$\cdot, 0$ & 1 & $\%$ & $\% \leqslant 1,7 \vee$ & 0 & $\%$ ro, . & $r$ & | & $\varepsilon$ & يفرق بين المياه وباقى & $\varepsilon \wedge$ \\
\hline$* 1,0$. & r & $\% \wedge 7,11$ & \% & 1 & $\%$ ro, . & r & $\%$ & $\Lambda$ & يقوم بفتح الزجاجة بسهولة & 07 \\
\hline $\begin{array}{c}1 T, 0 \text {. } \\
*\end{array}$ & 1 & $\% 91,7 \vee$ & \% & 1 & \% & 1 & \% & 1 . & يقدر علي مله الكوب بنفسه (إيجابي) & $7 V$ \\
\hline
\end{tabular}

يتضح من جدول(9 (1) أنه توجد فروق ذات دلالة معنوية فى جميع العبار ات بين استجابات الأطفال

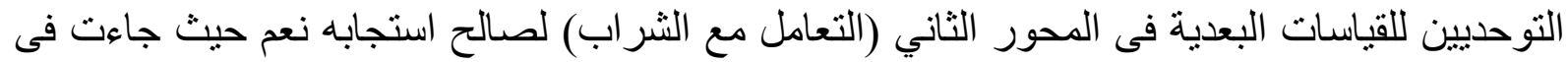

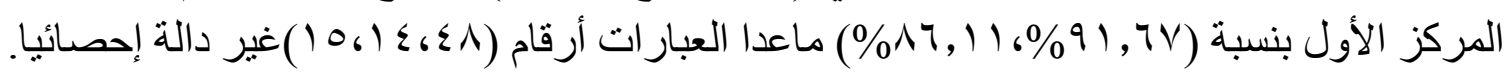

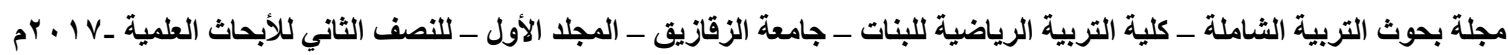


$-99-$

دور الألعاب في تنمية العناية بالذات لذوي الاحتياجات الخاصة

\section{جدول(ץ)}

التكرارات والنسب المئوية والأهمية النسبية وكاب للقياسات البعدية لاي الأطفال

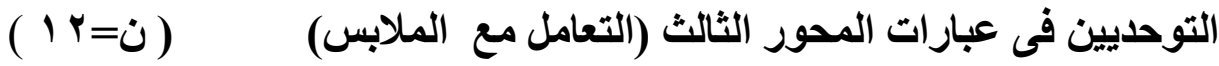

\begin{tabular}{|c|c|c|c|c|c|c|c|c|c|c|}
\hline \multirow{2}{*}{ كاץ } & \multirow{2}{*}{ الترنيب } & \multirow{2}{*}{$\%$} & \multicolumn{2}{|l|}{ ע } & \multicolumn{2}{|c|}{ 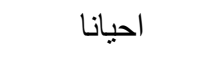 } & \multicolumn{2}{|l|}{ 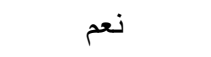 } & \multirow{2}{*}{ 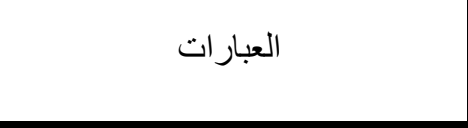 } & \\
\hline & & & $\%$ & ك & $\%$ & ك & $\%$ & ك & & \\
\hline$* 7,0$. & r & $\% \wedge 7,11$ & $\% \cdot, \cdots$ & . & $\% \leqslant 1,7 \mathrm{~V}$ & 0 & \%०ג, & V & يعرف الفرق بين البنطال و الشورت & 1 \\
\hline$* \eta, \ldots$ & $\varepsilon$ & \% & $\% 17,7 \vee$ & r & $\% 17,7 \mathrm{~V}$ & r & $\%$ & $\wedge$ & 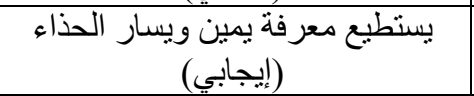 & rV \\
\hline$* 1 \cdot, 0$ & 1 & $\% 91,7 \mathrm{~V}$ & $\% \cdot, \cdots$ & & $\%$ ro, . & $r$ & $\% \vee \vee, \cdots$ & 9 & يققل سوستة البنطال (إيجابي) & $r \wedge$ \\
\hline$\varepsilon, 0$ & $\varepsilon$ & \% & \%^,r & 1 & \% & $\varepsilon$ & \%०ג,r & 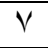 & يلبس فردتي الحذاء بنظام (إيجابي) & rq \\
\hline$* 1 \wedge, 0$ & ir & 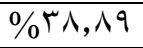 & $\% 91,7 \mathrm{~V}$ & 11 & $\% \cdot, \cdots$ & & \% & 1 & يعرف فردتي الحذاء(إيجابي) & $\sum r$ \\
\hline$* 1 \leq, \cdots$ & IT & $\% ґ \wedge, \wedge q$ & $\%$ & $1 \cdot$ & $\% \backslash 7,7 \mathrm{~V}$ & $r$ & $\% \cdot, \cdots$ & & يفرق بين فردني الحذاء(إيجابي) & or \\
\hline$* 7,0$. & 1 . & $\% \leqslant V, r Y$ & $\% 77,7 \vee$ & $\wedge$ & $\%$ ro, $\ldots$ & $r$ & \% & 1 & يحب ارتداءالملابس بدون زراير أو & or \\
\hline$\varepsilon, 0$ & 9 & $\% 0 \cdot, \cdots$ & \%०ג, & V & \% & $\varepsilon$ & \% & 1 & يحب لبس الجاكت (إيجابي) & $T r$ \\
\hline$r, \cdots$ & V & $\% 00,07$ & $\% 0 \cdot, \cdots$ & 7 & \% & $\varepsilon$ & $\% 17,7 \mathrm{~V}$ & $r$ & يفضل ارتداء القبعة (إيجابي) & $\overline{7 r}$ \\
\hline$\varepsilon, 0$ & 0 & $\% \vee 0, \ldots$ & \% & $\varepsilon$ & \%^,r & 1 & \%०ג,ru & $\mathrm{V}$ & يخلع حذائه بمفرده دون مساعدة(إيجابي) & 11 \\
\hline$* Y \leq, \cdots$ & 14 & \% & $\% 1 \cdots, \cdots$ & IT & $\% \cdot, \cdots$ & & $\% \cdot, \cdots$ & & يصعب عليه خلع الفانلة (سلبي) & IT \\
\hline., 0 & 7 & $\% 71,11$ & $\% \leqslant 1,7 \mathrm{~V}$ & 0 & \% & $\varepsilon$ & $\%$ Yo, . & $r$ & يقطع الفانلة عند خلعها(سلبي) & $1 T$ \\
\hline$r, 0$. & V & $\% 00,07$ & $\% 0 \wedge, r \mu$ & V & $\% 17,7 \mathrm{~V}$ & $r$ & $\%$ Yo, $\cdots$ & $r$ & يمزق الملابس عند خلعها(سلبي) & $r$ \\
\hline$* 7,0$ & $r$ & $\% \wedge 7,11$ & \%^,r & 1 & $\%$ ro, . & $r$ & $\%$ & $\wedge$ & يفلك زر اير القميص(إيجابي) & $\bar{T}$ \\
\hline$\varepsilon, 0$. & $\varepsilon$ & \% & \% & 1 & ( & $\varepsilon$ & \%०ג, & $V$ & يقدر علي خلع الملابس الداخلية & 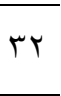 \\
\hline$* 1 \wedge, 0$ & $1 \varepsilon$ & $\% 9 V, Y r$ & $\% \cdot, \cdots$ & $\cdot$ & $\%$ & 1 & $\% 91,7 \mathrm{~V}$ & 11 & يقدر على خلع التيشيرت(إيجابي) & $\varepsilon r$ \\
\hline$* 7,0$ & $\Lambda$ & $\% \circ Y, \vee \wedge$ & $\%$ \%า, ТV & $\Lambda$ & $\%$ & 1 & $\%$ Yo, . & $r$ & يقطع الملابس عند خلعها(سلبي) & $\varepsilon \varepsilon$ \\
\hline$* 7,0$ & r & $\% \wedge 7,11$ & \% & 1 & $\%$ Yo, . & $r$ & $\% 77,7 \mathrm{~V}$ & $\Lambda$ & يصعب علية خلع الملابس(سلبي) & $\leqslant 0$ \\
\hline$* 7,0$ & $r$ & $\% \wedge \neg, 11$ & $\%$ & 1 & $\%$ ro, $\cdots$ & $r$ & $\% 77,7 \mathrm{~V}$ & $\Lambda$ & يصعب عليه خلع الحذاء(سلبي) & $\sum 7$ \\
\hline 1,0 & 0 & $\% \vee 0, \ldots$ & $\% 17,7 \vee$ & r & $\% \leqslant 1,7 \mathrm{~V}$ & 0 & $\% \varepsilon 1,7 \vee$ & 0 & يخرج رأسه من الملابس ببساطة & $0 \leqslant$ \\
\hline$\varepsilon, 0$. & $\varepsilon$ & \% & \% & 1 & \% & $\varepsilon$ & \% & V & يخلع ملابسه بنفسه داخل الحمام & 09 \\
\hline$* 1 \cdot, 0$ & 11 & $\% \varepsilon 1,7 V$ & $\% \vee 0, \cdots$ & 9 & $\%$ Yo, $\cdots$ & $r$ & $\% \cdot, \cdots$ & $\cdot$ & يخلع غطاء الر أس أولاً (إيجابي) & $7 \varepsilon$ \\
\hline$\varepsilon, 0$. & $\varepsilon$ & \% & \% & 1 & ( & $\varepsilon$ & \%०ג, & V & يقدر على خلع الأكمام بسهولة & 70 \\
\hline$* 4,0$. & $1 \cdot$ & $\% \leqslant V, r Y$ & $\% 77,7 \vee$ & $\wedge$ & $\%$ ro, . & $r$ & \% & 1 & يصعب عليه فلك أزرار أكمام الجاكت & 77 \\
\hline
\end{tabular}

يتضح من جدول(· · ) أنه توجد فروق ذات دلالة معنوية بين استجابات الأطفال التوحديين للقياسات

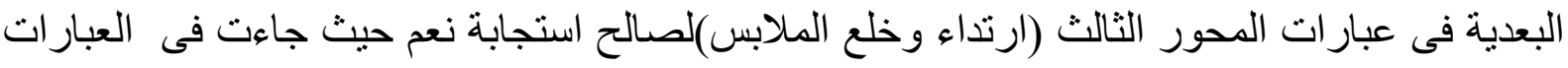

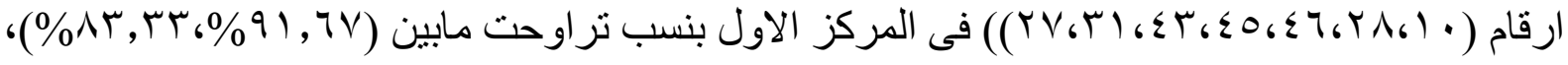

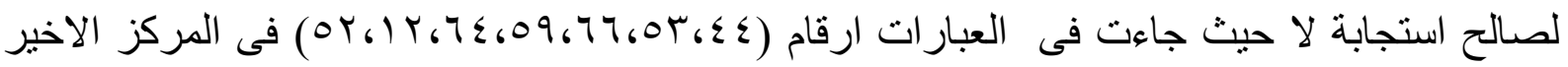

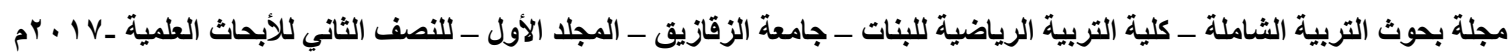


$-1 \ldots$

دور الألعاب في تنمية العناية بالذات لذوي الاحتياجات الخاصة

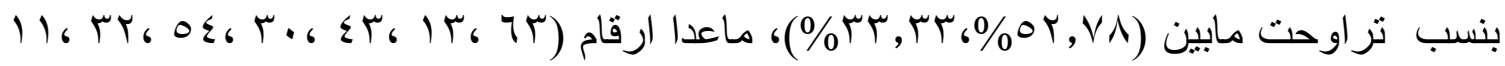

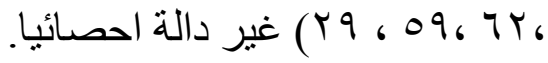

\section{جدول(Y)}

التكرارات والنسب المئوية والأهمية النسبية وكاץ للقياسات البعدية لاي الأطفال

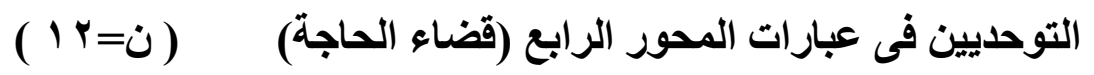

\begin{tabular}{|c|c|c|c|c|c|c|c|c|c|c|}
\hline \multirow{2}{*}{ كاץ } & \multirow{2}{*}{ الترتيب } & \multirow{2}{*}{$\%$} & \multicolumn{2}{|l|}{$y$} & \multicolumn{2}{|c|}{ احيانا } & \multicolumn{2}{|l|}{ نعم } & \multirow{2}{*}{ العبار ات } & \\
\hline & & & $\%$ & ك & $\%$ & ك & $\%$ & ك5 & & \\
\hline$* 7,0$. & $\varepsilon$ & $\% \leqslant V, Y r$ & \% \% \% & $V$ & $\% \leq 1,7 V$ & 0 & $\% \cdot, \cdots$ & & 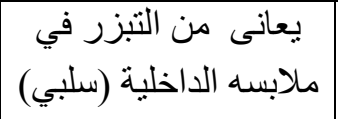 & 7 \\
\hline$* 7,0$. & $\varepsilon$ & $\% \leqslant V, Y r$ & $\%$ & $\Lambda$ & $\%$ ro,.. & $r$ & \% & 1 & يخلع جميع ملابسة ليتبرز(سلبي) & V \\
\hline$* 1,0$. & $r$ & $\% 91,7 V$ & $\% \cdot, \cdots$ & & $\%$ ro,.. & $r$ & $\% \vee 0, \ldots$ & 9 & 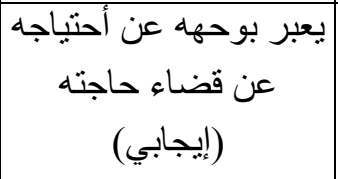 & r \\
\hline$* 7,0$. & $\varepsilon$ & $\% \leqslant V, Y Y$ & \% \% & $V$ & $\% \leq 1,7 V$ & 0 & $\% \cdot, \cdots$ & & حاجاته في الحمام (سلبي) عضاء) & $r \varepsilon$ \\
\hline$* 1 \leq, \ldots$ & 1 & $\% 9 \varepsilon, \varepsilon \varepsilon$ & $\% \cdot, \cdots$ & & $\% 17,7 \mathrm{~V}$ & r & \% & $1 \cdot$ & مساعدة الغير (إيجابي حاجنه دون) & $\leqslant 1$ \\
\hline$* q, 0$. & r & $\% \wedge \wedge, \wedge q$ & \% & 1 & $\% 17,7 \mathrm{~V}$ & r & $\% \vee 0, \ldots$ & 9 & تنتابه أعر اض هستيرية & 01 \\
\hline
\end{tabular}

يتضح من جدول (Yl) أنه توجد فروق ذات دلالة معنوية لدى استجابات الأطفال التوحديين للقياسات البعدية فى عبار ات المحور الرابع (عملية الإخراج) فى جميع العبارات لصالح استجابة نعم

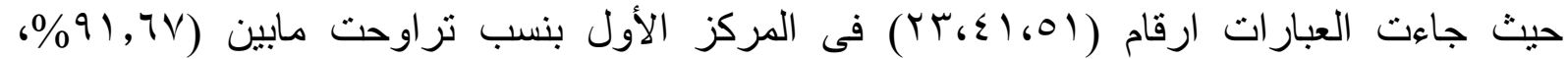

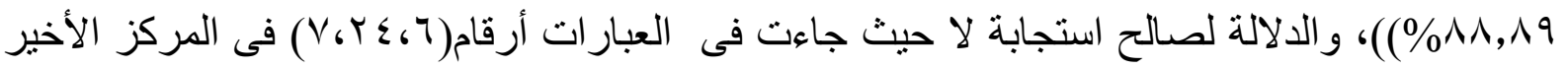
بنسبة (\%

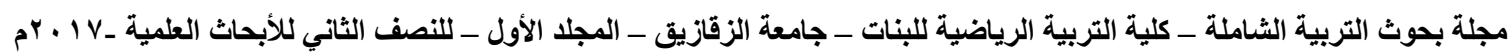


$-1 \cdot 1-$

\section{جدول(Y)}

التكرارات والنسب المئوية والأهمية النسبية وكاب للقياسات البعدية لاي الأطفال

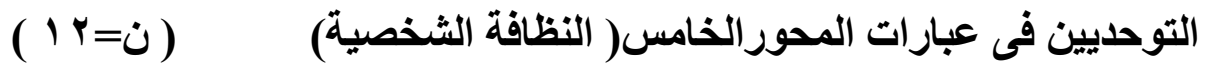

\begin{tabular}{|c|c|c|c|c|c|c|c|c|c|c|}
\hline \multirow{2}{*}{ كاץ } & \multirow{2}{*}{ |الترتيب | } & \multirow{2}{*}{$\%$} & \multicolumn{2}{|l|}{$\bar{\gamma}$} & \multicolumn{2}{|c|}{ احيانا } & \multicolumn{2}{|c|}{ نعم } & \multirow{2}{*}{ العبارات } & \\
\hline & & & $\overline{\%}$ & st & $\overline{\%}$ & ك & $\overline{\%}$ & ك & & \\
\hline$* 1 \leq, \cdots$ & 7 & $\% \leftrightarrow \wedge, \wedge q$ & \% & 1. & $\%) 7,7 \vee$ & r & $\% \cdot, \cdots$ & l. & بخاف من غسل وجهابه & 9 \\
\hline$* 4,0$. & $\mu$ & $\% \wedge \cdot, 07$ & $\%$ ro,.. & $r$ & $\%$ & 1 & $\%$ & $\Lambda$ & بحب غسيل يده ورجله & ro \\
\hline$* 7, \cdots$ & $r$ & \% \% & $\%) 7,7 \vee$ & $r$ & $\%(7,7 \vee$ & r & \%า & $\Lambda$ & بالثامبو غسل شعره & $r q$ \\
\hline$* 4, \ldots$ & r & $\%$ & $\%$ & $\Lambda$ & $\%) 7,7 \vee$ & $r$ & $\%) 7,7 V$ & $r$ & برمى المياه على من (سلبي) & 00 \\
\hline *) & 0 & $\% \leqslant 1,7 \vee$ & سז, & 1. & $\%$ & 1 & $\%$ & 1 & الأظافربمفرده (سلبي) يخشى تقليم & 7. \\
\hline$* \wedge, \cdots$ & 1 & $\% \wedge \wedge, \wedge ৭$ & $\% \cdot, \cdots$ & · & سז, אח\% & $\varepsilon$ & $\%$ & $\lambda$ & العطور (إيجابي) & 71 \\
\hline$* 9,0$. & $\varepsilon$ & $\% \leqslant V, r Y$ & $\% \vee 0, \ldots$ & 9 & $\%$ & 1 & $\% 17,7 \vee$ & $r$ & بالثشامبو غلبل شعره) & $V$. \\
\hline$* 7,0$. & $r$ & $\% \wedge \cdot, 07$ & $\%$ ro,.. & r & $\%$ & 1 & $\%$ & $\Lambda$ & يحب الاستحمام بمفرده & V) \\
\hline
\end{tabular}

يتضح من جدول(Y T) أنه نوجد فروق ذات ذات دلالة معنوية لدى استجابات الأطفال التوحديين

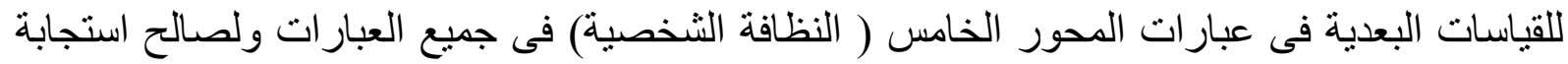

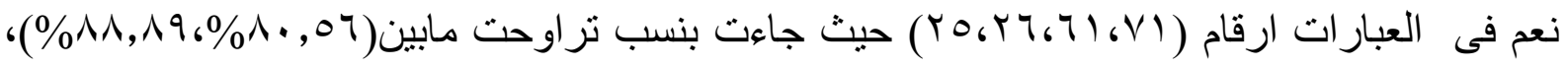

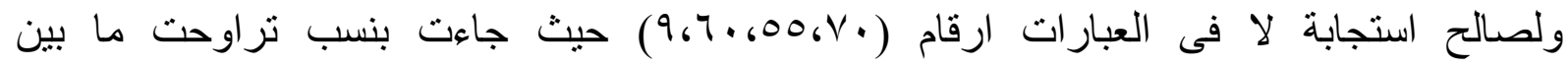

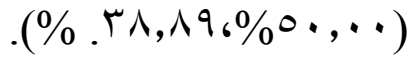

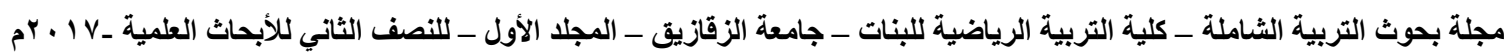


$-1 \cdot r-$

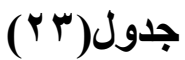

التكرارات والنسب المئوية والأهمية النسبية وكاץ للقياسات البعدية لدي الأطفال

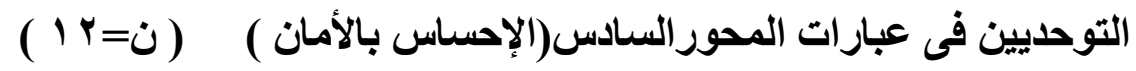

\begin{tabular}{|c|c|c|c|c|c|c|c|c|c|c|}
\hline \multirow{2}{*}{ كاץ } & \multirow{2}{*}{ الترتيب } & \multirow{2}{*}{$\%$} & \multicolumn{2}{|l|}{$\bar{y}$} & \multicolumn{2}{|c|}{ احيانا } & \multicolumn{2}{|l|}{ نعم } & \multirow{2}{*}{ العبار ات } & \multirow{2}{*}{ م } \\
\hline & & & $\%$ & ك & $\%$ & 5 & $\%$ & ك & & \\
\hline$* 9,0$. & 1. & $\% \leqslant V, r Y$ & $\% \vee 0, \ldots$ & 9 & \% & 1 & $\%) 7,7 \vee$ & r & بضرب وجها باليدين & 1 \\
\hline$* 7,0$. & 1 & $\% V Y, Y Y$ & $\% \wedge, r T$ & 1 & $\%$ & $\wedge$ & $\%$ ro, . & $r$ & $\begin{array}{c}\text { يخاف من الذهاب لزيارة } \\
\text { أقاربه (سلبي) }\end{array}$ & $r$ \\
\hline$r, 0$. & 0 & $\% \vee \vee, \vee \wedge$ & $\%$ ro, . & $r$ & $\%) 7,7 \vee$ & $r$ & \% \%, \% & $v$ & بيتطيع فتح باب الغرفة & $\wedge$ \\
\hline$r, \ldots$ & $\wedge$ & $\% 71,11$ & $\%$ & 7 & $\% 17,7 \vee$ & $r$ & זr, & $\varepsilon$ & يلعب بالاشياء الخطيرة & 17 \\
\hline$r, \ldots$ & 9 & $\% 00,07$ & $\%$ & 7 & שr,זr\% & $\varepsilon$ & $\% 17,7 \vee$ & r & بضع الاقلام في عينها & IV \\
\hline$* 7,0$. & r & $\% \wedge 7,11$ & $\% \wedge, r T$ & 1 & $\%$ ro, . & $r$ & $\% 77,7 \vee$ & $\wedge$ & 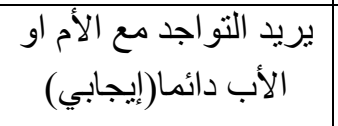 & 11 \\
\hline$\cdot, \cdots$ & V & $\% 77,7 \vee$ & |rז, & $\varepsilon$ & זr, & $\varepsilon$ & זr, & $\varepsilon$ & $\begin{array}{l}\text { يحب الخروج إلى (إيجابي) } \\
\text { الحدائق) }\end{array}$ & ro \\
\hline$* 1 \leq, \ldots$ & 9 & $\% \leq \varepsilon, \leqslant \leq$ & \% & 1. & $\% \cdot, \cdots$ & & $\% 17,7 \mathrm{~V}$ & r & الصحاب والذهاب للدى & T \\
\hline *1r,o. & r & $\% 91,7 V$ & $\% \wedge, r T$ & 1 & \% & 1 & \% \% \% & 1. & يقدر على اللعب مع رفائه (إيجابي) & $\leqslant 9$ \\
\hline$* \backslash \wedge, 0$. & 1 & $\% 9 \vee, r Y$ & $\% \cdot, \cdot$ & · & $\%$ & 1 & $\% 91,7 \vee$ & 11 & "يحب التواجد فى المنزل(سلبي) & 0. \\
\hline$* \uparrow, 0$. & $\varepsilon$ & $\% \wedge \cdot, 07$ & $\%$ ro, . & $r$ & \% & 1 & $\% 77,7 \vee$ & $\wedge$ & $\begin{array}{c}\text { ينام بجانب الأم بمفردة } \\
\text { يلبي) }\end{array}$ & ov \\
\hline$* 7,0$. & $\varepsilon$ & $\% \wedge \cdot, 07$ & $\%$ ro,... & $r$ & \% & 1 & $\%$ & $\wedge$ & 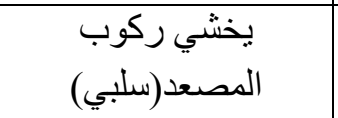 & $0 \wedge$ \\
\hline
\end{tabular}

ـ كاب عند مستوى 0, 0, 0,

مجلة بحوث التربية الثاملة _ كلية التربية الرياضية للبنات - جامعة الزقازيق ـ المجلد الأول ـ للنصف الثاني للأبحاث العلمية _ V ا Y م 
يتضح من جدول(V) أ نه توجد فروق ذات ذلاتلة معنوية لدى استجابات الأطفال

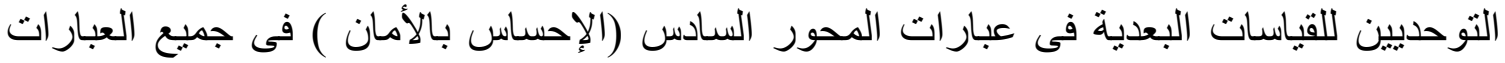

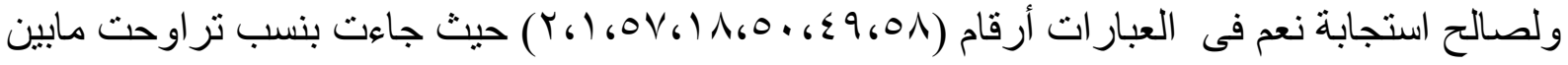

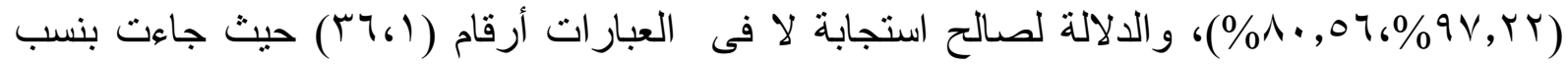

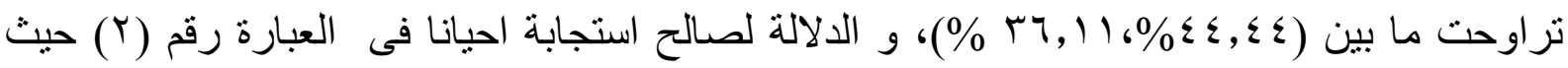

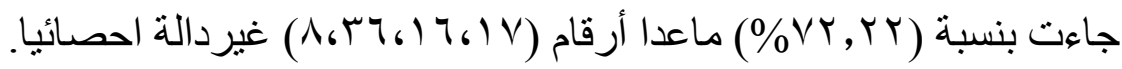

ب ـ مناقشة نتائج في ضوء و اقع البيانات والمعالجات الإحصائية المناسبة و النتائج السابق عرضها توصلت الباحثة الى

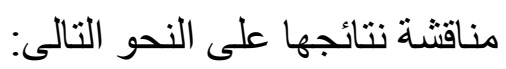

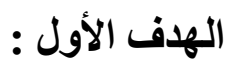
ا - بناء مقياس مهار ات العناية بالذات لدي الأطفال التوحديين. فى ضوء هذا الهدف تم تحليل آر اء أعضاء هيئة التدريس والخبر اء المتخصصين في مجال علم النفس الرياضي و الفئات الخاصة وبذللك أصبح المقياس مكون من سنة محاور رئيسية كالآتي: المحور الأول : التعامل مع الطعام ويقيسه (0 1 ) عبارة . المحور الثاني : التعامل مع الثراب و يقيسه (T) عبارة . المحور الثالث : التعامل مع الملابس ويقيسه ( ؟ ب) عبارة . المحور الر ابع : قضاء الحاجة ويقيسه (ج) عبارة . المحور الخامس : النظافة الثخصية ويقيسه (^) عبارة . المحور السادس : الإحساس بالأمان ويقيسه (ب ا ) عبارة . وضرورية لتقويم مستوى أداء الطفل المتوحد، و هذا ما يتفق مع ماأشارت إليه در اسة كل من

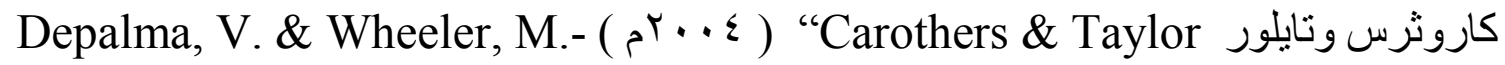

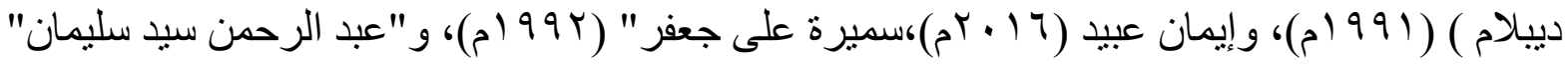

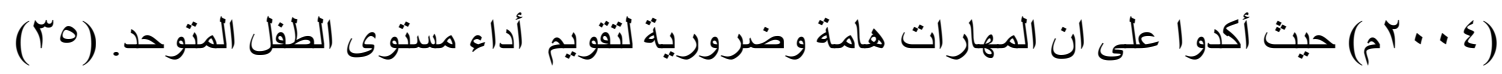

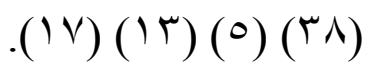
أما بالنسبة للنتائج التى توصلت اليها الباحثة من خلال المعالجات الاحصائية للبيانات التى تم الحصول

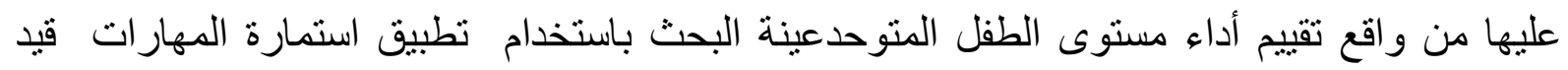
البحث فقد أسفرت عن مايلى: ـ مناقشة نتائج تساؤل البحث: 


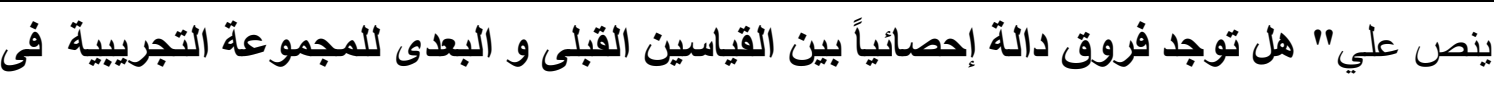
مستوي أداء مهارات العناية بالأات لاى الأطفال التوحديين لصالح القياس البعدى".

المحور الأول:التعامل مع الطعام

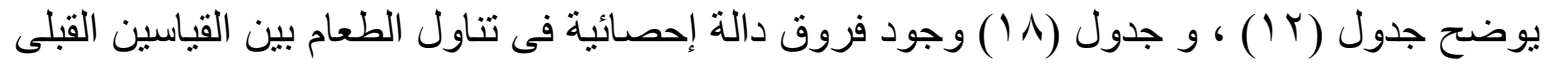
و البعدى وذللك لصالح القياس البعدى .

وتؤكد ذلك در اسة "إيمان عبيد" (7 ( • r) حيث أثتبت فعالية البرنامج المقترح فى تتمية مهارة تناول الطعام و الشراب لاى الاطفال التوحديين حيث أتيحت لهم الفرصة فى الاعتماد على أنفسهم وتحقيق الثقة بالنفس والتحرر من الاعتماد علي الام حيث يعبر الطفل عن نفسه بالطريقة التى يفضلها أثناء تناول

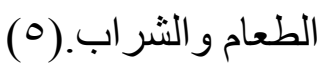

و أثات دراسة " الغامدي" (r . •rم) أن البرامج التدريبية هامة للفئات الخاصة لانها تساعدهم فيقضاء أحتياجاتهم من مأكل ومشرب وملبس.(Tr) (Y) كما ثري الباحثة أن تلك النتيجة معناها أن الأطفال التوحديين أصبح لهم القدرة علي تناول الطعام و الثراب بكفاءة وحمل أدوات المائدة من أطباق وملاعق و أكواب وأستخدامها بسهولة، ويسروثقة،هو عدم الر هبة و الخوف من سقوطها.

إلي جانب أن تطبيق البرنامج جعل الطفل بعتاد علي حمل والتعامل بثقة مع أدوات المائدة بطريقة

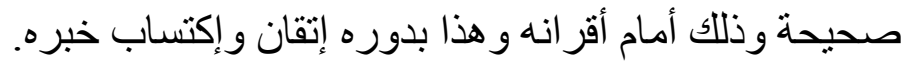
المحور الثاني: التعامل مع الثراب

يوضح جدول (ب ا )، و جدول (9 (1) وجود فروق دالة إحصائية فى ثتاول الثر اب بين القياسين القبلى و البعدى وذللك لصالح القياس البعدى .

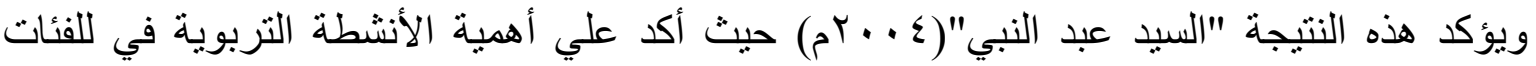
الخاصة حيث أنها تزيد من قدرتهم علي التمكن من حمل الأشياء و التعامل معها. كما تري الباحثة في هذا الصدد أن الألعاب والأنثطة تساعد التوحديين علي الاعتياد علي أدوات الثر اب كالكوب و الزجاجة و عدم سكبها، وأيضا عدم إحتياج الطفل للمساعدة من الغير. ومن وجهة نظر الباحثة أن الأطفال في هذه المرحلة السنية بحاجة إلي إتقان مهارة تتاول الثراب وذللك لملاحظة الباحثة إحتياجهم الثنديد للمياه وتناولهم أكثر من أقر انهم الأسوياء، فيجب توخي الحهن الحذر في في

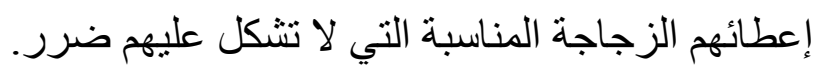
المحور الثالث: التعامل مع الملابس يوضح جدول (ع ())، جدول (· ( ) وجود فروق دالة إحصائية فى كيفية إرتداء الملابس وخلعها

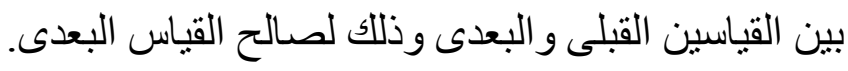

مجلة بحوث التربية الثاملة ـ كلية التربية الرياضية للبنات - جامعة الزقازيق ـ المجلد الأول ـ للنصف الثاني للأبحاث العلمية _ V ـ rم 
وبذلك أشار "رمضنان القذافي" (ع . . rم) فى أن البرامج التدريبية أتاحت للأطفال التوحديين

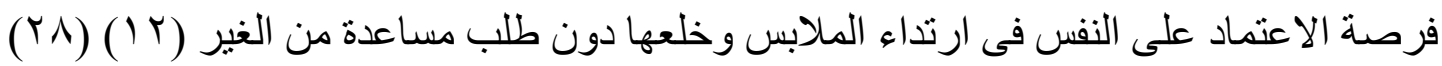
واختلف"محمد خطاب" (0 . . بم) أن الأطفال التوحديين ليس لهم القرة علي تنظيم ملابسهم بشكل مهندم بدون مساعدة الامهات لأنها تحتاج مهارة وقدرة تفوق قدر اتهم. وتري الباحثة في هذا الصدد أن الطفل التوحدي يستطيع التعامل مع ملابسه من إرتداء وخلع بالتدريب

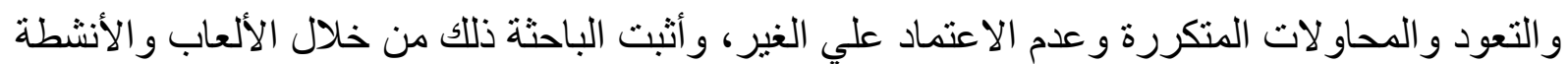

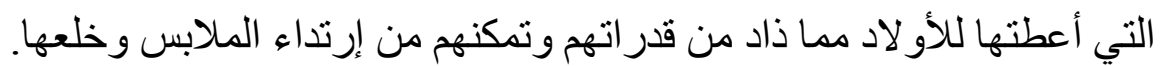
المحور الخامس: قضاء الحاجة يوضح جدول (0) (10) جدول (Yl) وجود فروق دالة إحصائية فى عملية الإخر اج بين القياسين القبلى

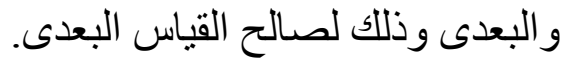

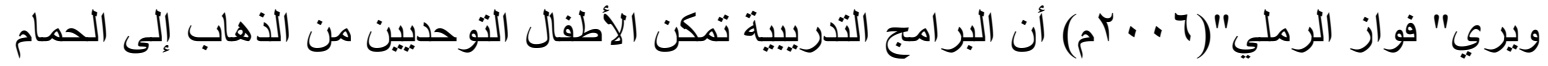
بمفردهم، والتبول داخل التواليت بدون حفاض، وبدون أن يطلبوا مساعدة من الآخرين وكذلك خلع آلت

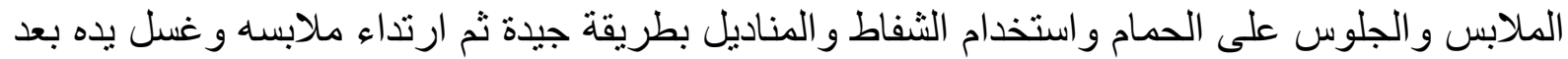

(Y) الانتهاء من هذه العملية

كما يختلف "نيهال النجومي (r I • rم) مع تلاك النتيجة في أن البر امج لا تصلح بمفردها لتعويد الأطفال التوحديين علي الإخر اج ولكن من الضروري إستخدام الأدوية المناسبة. (سب) ومن وجهة نظر الباحثة أن البرنامج المقترح له تأثثير إيجابي علي الأطفال التوحديين حيث أصبح لهم القدرة علي الإخر اج في أوقات محددة ومنظمة بمفردهم دون المساعدة من الغير.

المحور السادس: النظافة الشخصية يوضح جدول (T (I)، جدول (YY) وجود فروق دالة إحصائياً فى النظافة الشخصية بين القياسين القبلى و البعدى وذللك لصالح القياس البعدى.

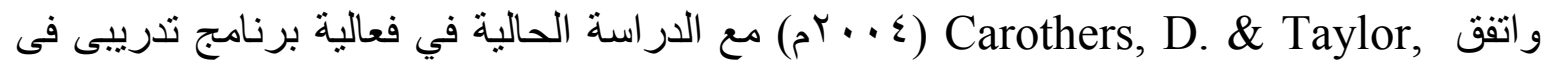
تحسن مهار ات الأطفال التوحديين الخاصة بغسل اليدين والوجه والأسنان وتمشيط الشعر واستخدام

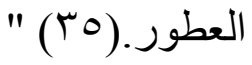
وتختلف مع "سهي أحمد" (1 · +rم) في ضرورة عدم ترك الأطفال ذوي الاحتياجات الخاصة القيام

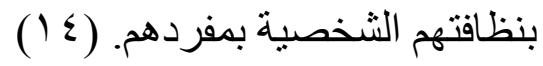
وتري الباحثة أن البرنامج المقترح يساعد الأطفال التوحديين علي القيام بنظافتهم الثخصية من الاغتسال وغسل اليدين والثعر والأسنان، و ومن وجهه نظر الباحثة أن هذا المحور يعد من أهم المحاور

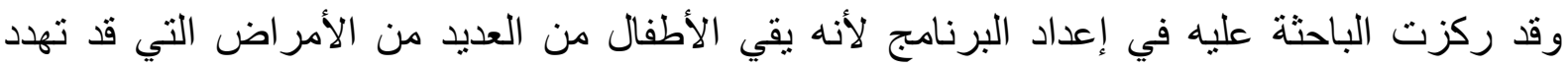




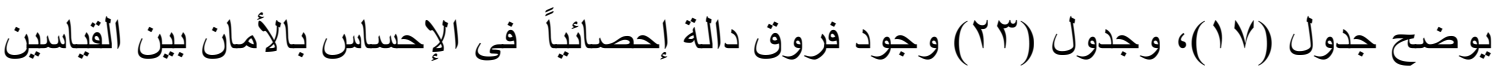
القبلى و البعدى وذللك لصالح القياس البعدى. وندول

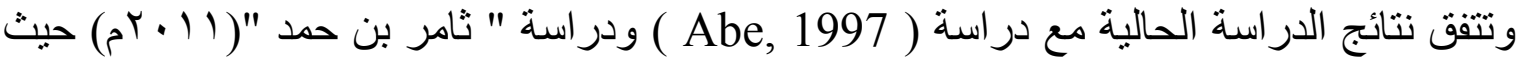

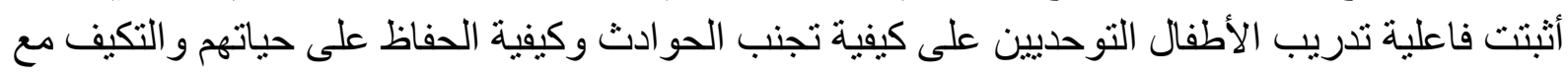

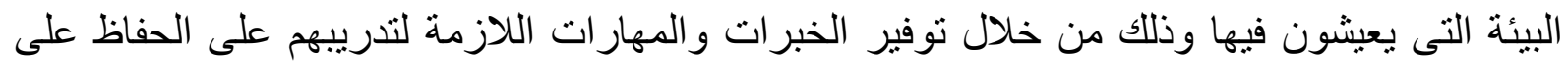

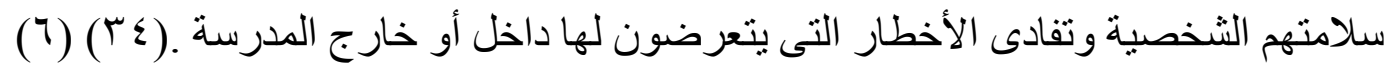

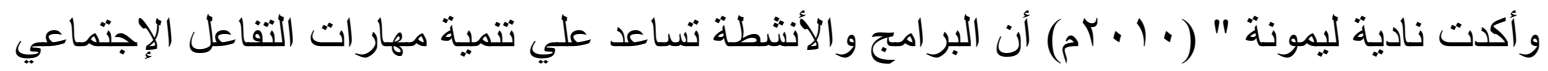

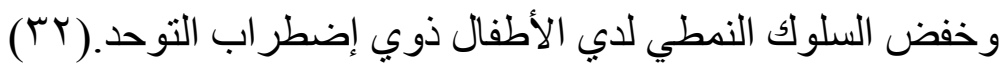

وتري الباحثة أن البرنامج المقترح ساعد الأطفال التوحيين في الحفاظ علي أنفسهم من المخاطر وتوخي الحذر قدر الإمكان، وشعور هم بالأمان مع الباحثة وفريق العمل.

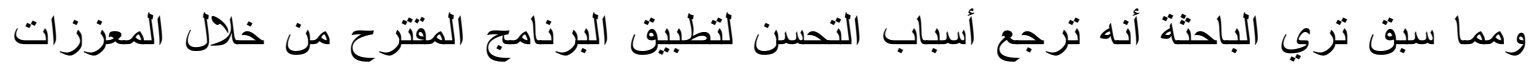

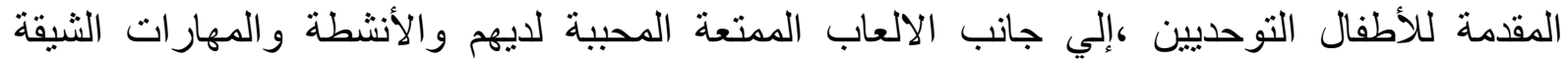

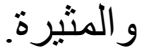
وأيضا لايمكن أن نغفل أساليب المعززات المستخدمة في البرنامج التي كان لها أكبر الأثر في تحسن مهار ات العناية بالذات للأطفال التوحيين من حلوي النغ وألعاب و أنشطة و هدابيا .

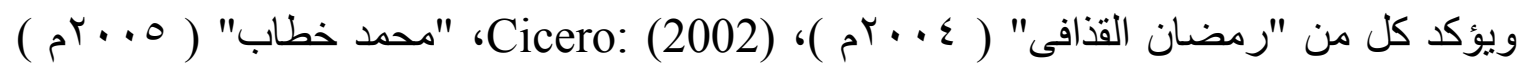

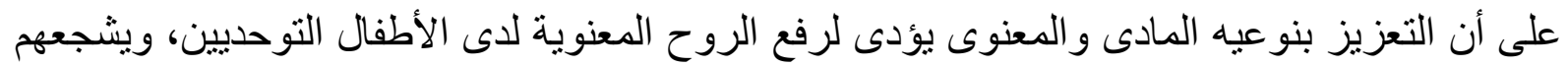

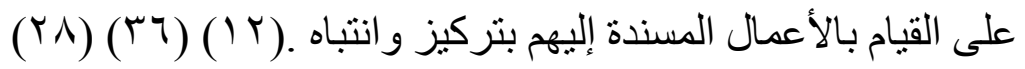
هذا وقد راعت الباحثة عمل تقييم في نهاية كل مرحلة للاطفال التوحديين لمعرفة مدي أستجابتهم للبرنامج ونسبة تقدمه في مهار ات العناية بالذات.

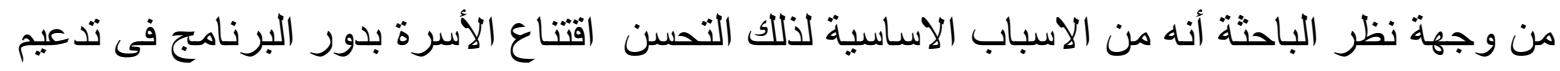

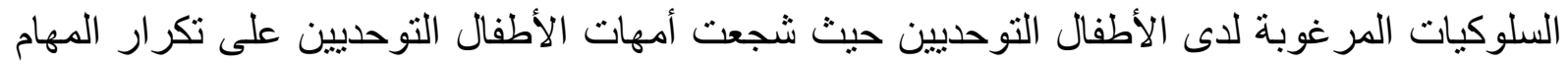

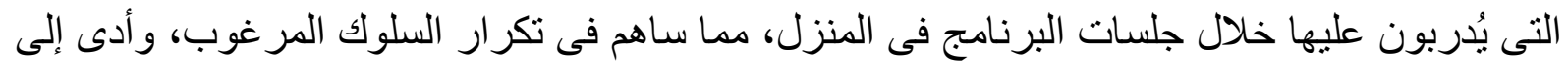

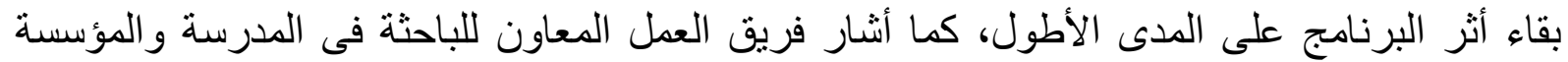

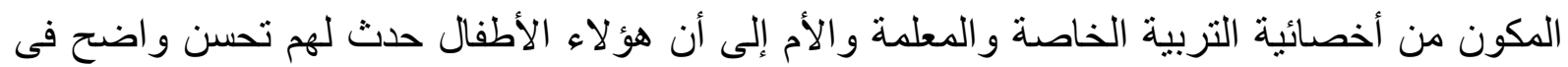
سلوكياتهم الخاصة بمختلف مهار ات العناية بالذات.

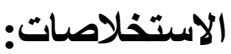

1 - يتكون مقياس مهار ات العناية بالذات من ستة محاور كالاتي:

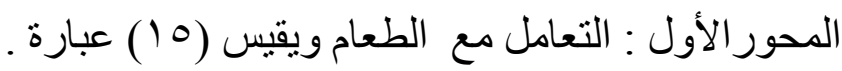

مجلة بحوث التربية الثاملة ـ كلية التربية الرياضية للبنات - جامعة الزقازيق ـ المجلد الأول ـ للنصف الثاني للأبحاث العلمية _ V ـ rم 
$-1 \cdot V_{-}$

المحور الثاني : التعامل مع الثراب و يقيس (ج) عبارة .

المحور الثالث : التعامل مع الملابس ويقيس (ع ب) عبارة .

المحور الر ابع : قضاء الحاجة ويقيس (T) عبارة .

المحور الخامس : النظافة الثخصية ويقيس (^) عبارة .

المحور السادس : الإحساس بالأمان ويقيس (سا ) عبارة .

ץ- توجد فروق دالة إحصائياً بين القياسين القبلى و البعدى للمجمو عة التجريبية فى مهار ات العناية بالذات لدى الأطفال التوحديين لصالح القياس البعدى. التوصيات:

ا ـ إستخدام المقياس المقتر ح كأداه للقياس و التقييم لباقي فئات الإعاقة. rـ تطبيق البرنامج العلاجي المقترح علي جميع المؤسسات ودور الرعاية والمدارس الخاصة بذوي الاحتياجات الخاصة.

r- تشجيع الباحثين في مجال علم النفس الرياضي لإجر اء أبحاث مشابهة علي تلك الفئة.

المراجع

ا ـ السيد عبد النبى السيد (ع . 두) : الأنشطة التربوية للأطفال ذوى الاحتياجات الخاصة مكتبة الانجلو

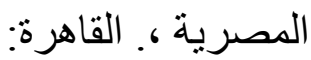

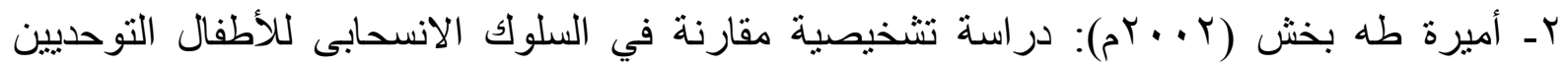

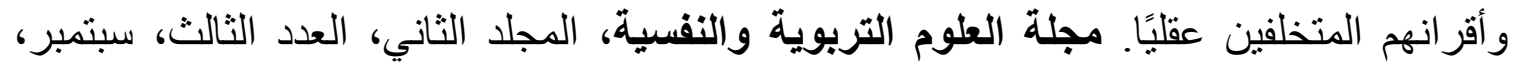

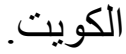
rـ أمين أنور الخولي، جمال الثافعي(9 . ․ rم):"بحوث في الرياضة والنمو الحركي للطقل"سلسلة التقافة الرياضية ، العدد(9 (1)، المكتبة المصرية للطباعة و النشرو التوزيع، الاسكندرية.

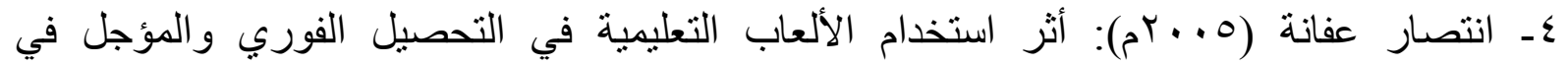

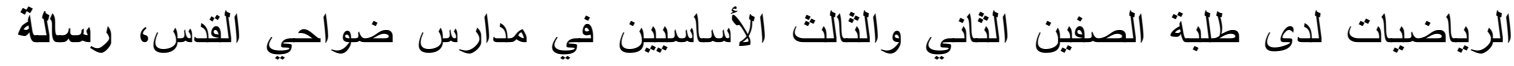
ماجستير غير منشورة، جامعة القدس. هـ إيمان عبيد (7 ( • rم): الألعاب المائية كمدخل لتحسين مهار ات العناية بالذات لدي الطفل التوحدي،

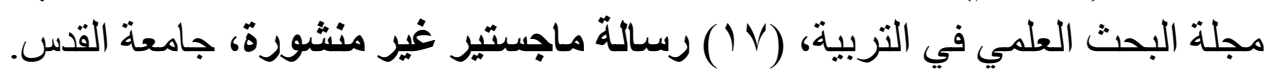

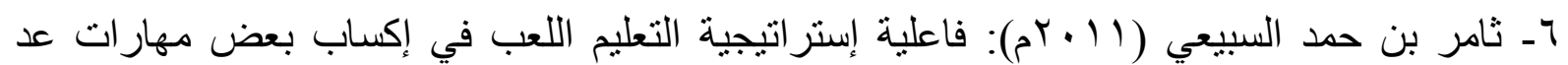
الأرقام في مادة الرياضيات للتناميذ ذوي الإعاقة الفكرية, رسالة ماجستير غير منشورة، التهية ، جامعة الملك سعود. V- خالد السيد ( ( + . Yم): فاعلية استخدام أنواع مختلفة من اللعب في تعديل بعض اضطر ابات السلوك

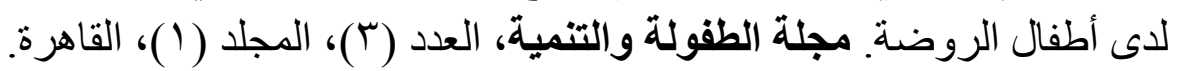

مجلة بحوث التربية الثاملة ـ كلية التربية الرياضية للبنات - جامعة الزقازيق ـ المجلد الأول ـ للنصف الثاني للابحاث العلمية _ V + Yم 


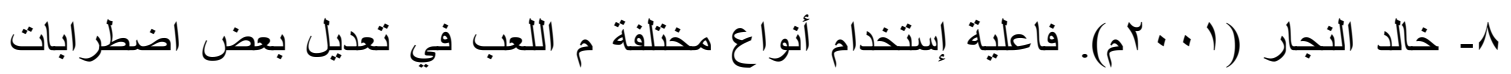

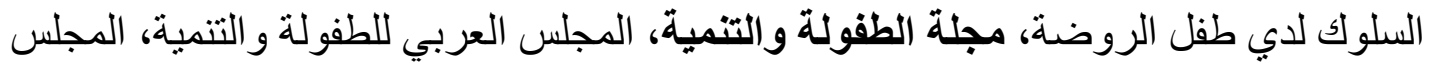
العربي للطفولة والتنمية، العدد ب، مجلد ا، القاهرة. 9- زينب شقير(0 . . rم): الإكتشاف المبكر والتشخيص لغير العاديين ، سلسلة ذوي الإحتباجات

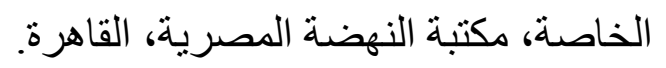
10 - رشاد موسي (r . . rم). علم نفس الإعاقة، مكتبة الأنجلو المصرية ، القاهرة.

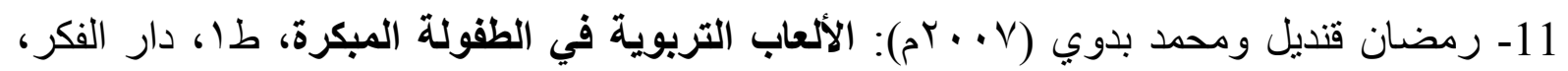
عمان.

12- رمضان القذافي (ع · · rم): رعاية الموهبين والمبدعين، المكتب الجامعي الحديث، الإسكندرية. 13- سميرة على جعفر (ع ا • rم): تعديل أكثر المشكلات السلوكية شيو عا لدى اطفال المدرسة الابتدائية

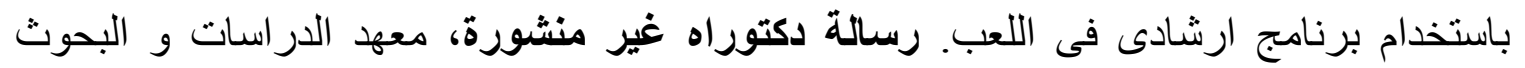
التربوية، جامعة القاهرة.

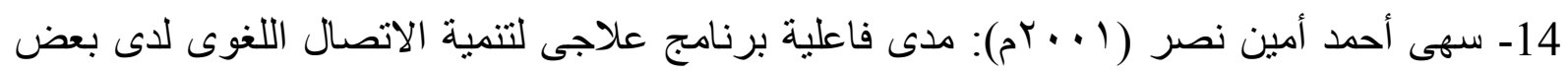
الأطفال التوحديين، رسالة دكتوراه غير منشورة، معهد الدراسات العليا للطفولة، قسم الدراسات النفسية و الاجتماعية، جامعة عين شمس.

15- سهيرمحمد سلامة ( ( . . r م): اللعب لادي الأطفال ذوي الإعاقة العقلية، دار القاهرة، مصر. 16- شمس ربيع شكرى سلامة (0 . . rم): التوحد - اللغز الأى حير العلماء والأطباء، دار النهار، القاهرة.

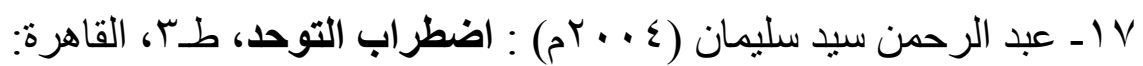

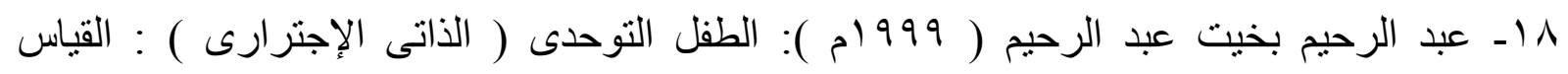

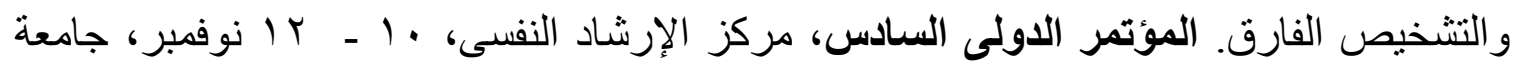
عين شمس. 9 ا ـ عبد القتاح عبد المجيد (V . . r م): سيكولوجية اللعب والترويج للعادين وذوي الإحتياجات الخاصة، مكتبة الأنجلو المصرية، القاهرة.

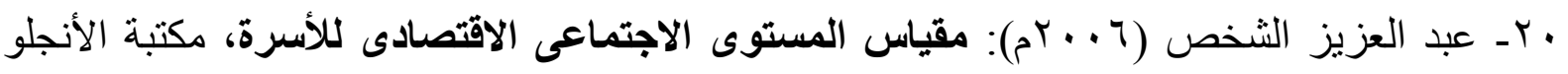
المصرية. اץـ عبد النبي السبد(ع + . rم): الأنشطة التربوية للأطفال ذوي الإحتياجات الخاصة، مكتبة الأنجلو

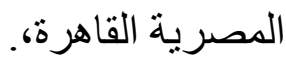

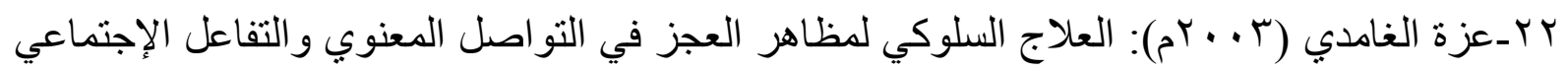

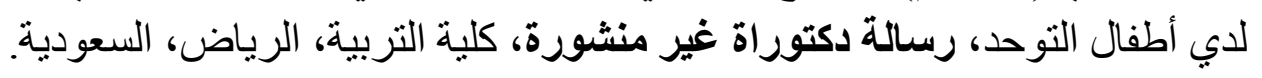

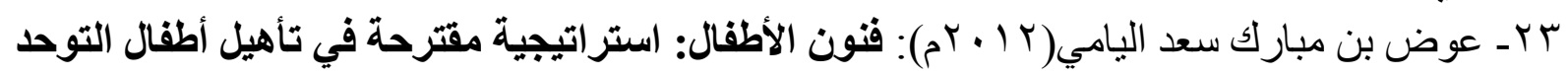

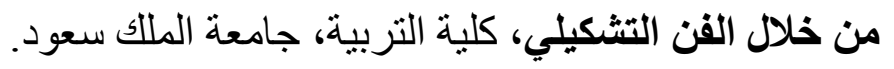

مجلة بحوث التربية الثاملة ـ كلية التربية الرياضية للبنات - جامعة الزقازيق ـ المجلد الأول ـ للنصف الثاني للابحاث العلمية _ V ـ r م 
$-1 \cdot 9$

دور الألعاب في تنمية العناية بالذات لذوي الاحتياجات الخاصة

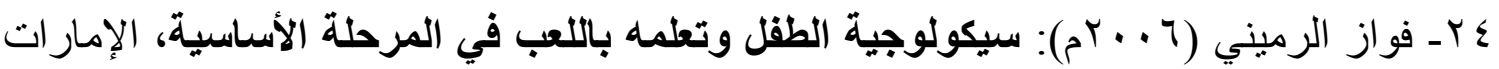

$$
\text { العربية المتحدة: دار الكتاب الجامعي. }
$$

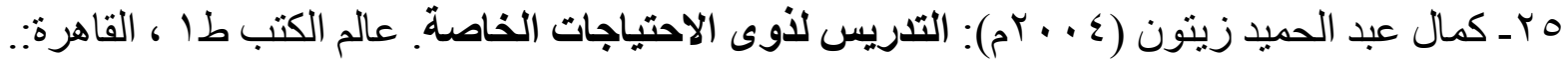

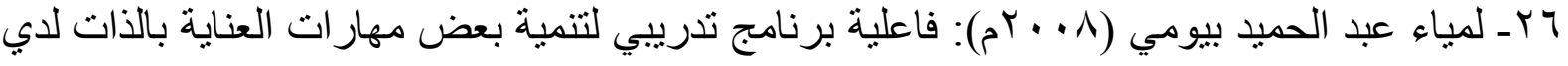
الاطفال التوحديين رسالة دكتور اه غير منشورة ، كلية التربية ، جامعة قناة السويس.

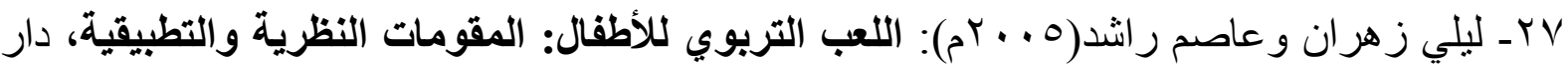

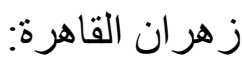

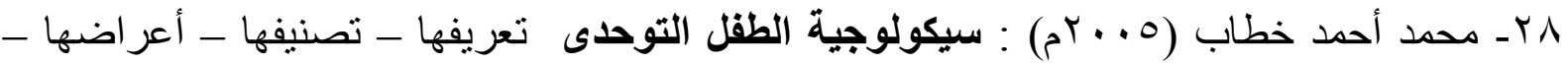

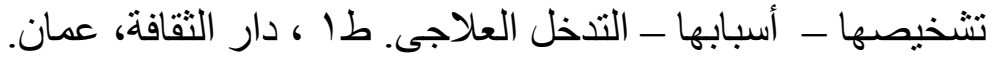

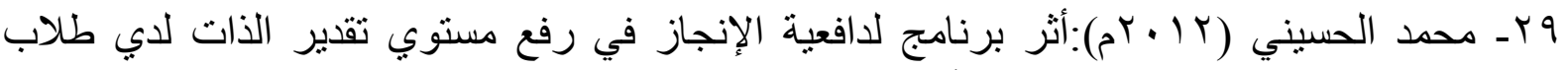

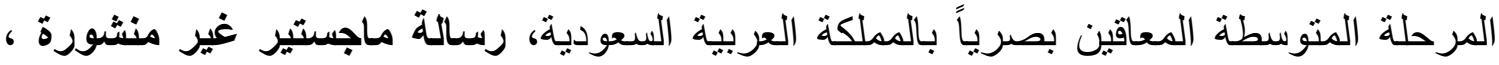
معهد الدر اسات التربوية، القاهرة.

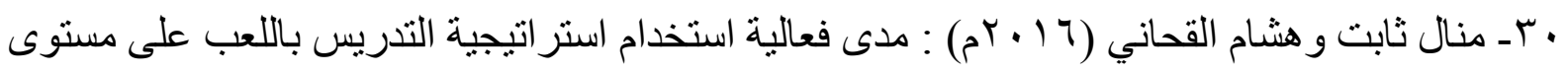
الدافعية والتحصيل الدراسي لدى التلاميذ المعاقين فكريًا، مجلة البحث العلمي في التربية،مكتبة

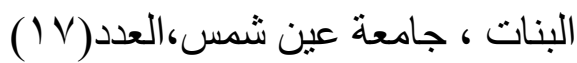

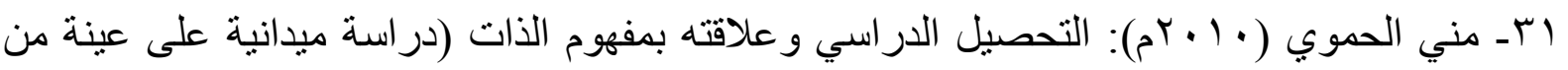
تلاميذ الصف الخامس- الحلقة الثانية - من التعليم الأساسي في مدارس محافظة دمشق الرسمية): مجلة جامعة دمشث- كلية التربية، جامعة دمشق. rr- نادية ليمونة (• ( • (r):برنامج تدريبي مستند إلي الأنشطة الفنية في تنمية مهارات التفاعل الإجتماعي وخفض السلوك النمطي لدي الأطفال ذوي إضطراب التوحد، رسالة دكتوراة غير منشورة، جامعة عمان العربية، الأردن.

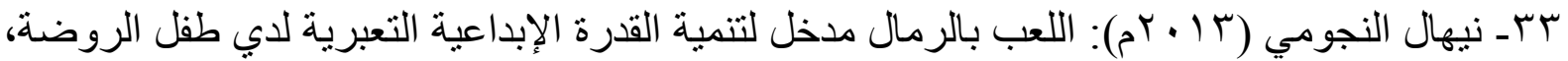
رسالة ماجيستيرغير منشورة، كلية تربية، جامعة طنطا.

34-Abe( 1997) Training on daily life I have autism and help them to protect themselves، Journal Focus on Autism and Other Developmental Disabilities

35-Carothers, D. \& Taylor, R. (2004): How to collaborate between teachers and parents to work together to teach special care skills to autistic children, Journal; Peer, Reviewed, Journal Focus on Autism and Other Developmental Disabilities, Vol. (19), No. (2), pp. 102-104

36- Cicero. F. \& Pfadt, a (2002). "Investigation of a Reinforcement Based Toilet Training Procedure for a Children with Autism, Research in Development Disabilities, Vol. (2), No. (1), pp. 61-63.

مجلة بحوث التربية الثاملة ـ كلية التربية الرياضية للبنات - جامعة الزقازيق ـ المجلد الأول ـ للنصف الثاني للأبحاث العلمية _ V ـ Yم 
37-Collins - B, (2003). Using video strategies to teach functional skills to students with moderate to severe. Guides-Non-Classroom; Opinion Popers; Speeches or - meeting - Papers, pp. 120-150.

. 38-Depalma, V. \& Wheeler, M. (1991). Learning self-care skills, functional programming for people with autism: A series, Indiana Resource Center for Autism, Indiana University.

39-Escalona, Wilde, Noodle and Lundy (2002): Effects on social behavior of autistic children Journal; Peer, Reviewed, Journal Focus on Autism and Other Developmental Disabilities

40-Scotland) (2002) 2-The impact of the early intervention program on improving communication skills in the pre-language stage. 